Key Words: Soil Contaminant Immobilization, Apatite, Zero-Valent Iron, Actinium, Cobalt, Chromium, Mercury, Lead, Barium, Strontium, Thallium, Thorium, Uranium

Retention: Permanent

\title{
REDUCTION OF CONTAMINANT MOBILITY AT THE TNX OUTFALL DELTA THROUGH THE USE OF APATITE AND ZERO-VALENT IRON AS SOIL AMENDMENTS (U)
}

Daniel Kaplan, Anna Knox, and Cathy Coffey

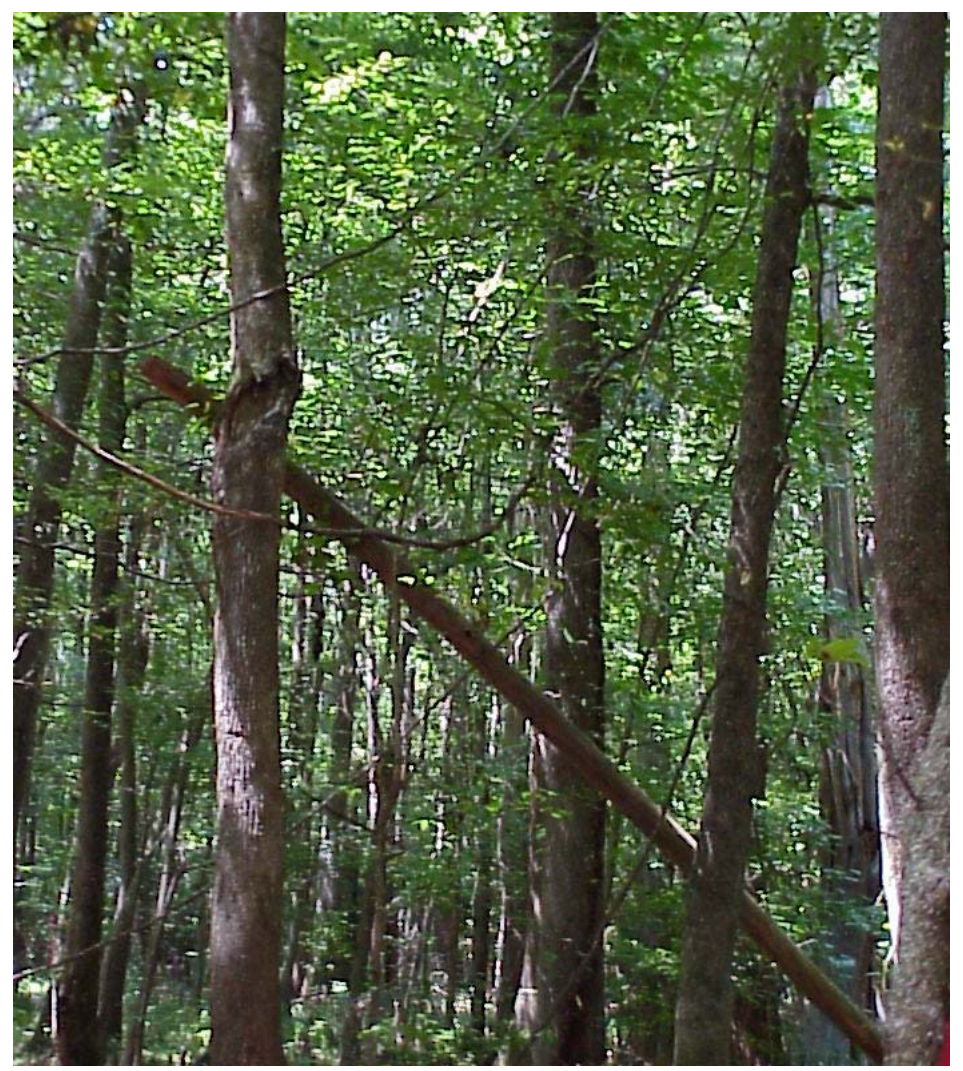

SEPTEMBER 27, 2002

Westinghouse Savannah River Company

Savannah River Site

Aiken, SC 29808

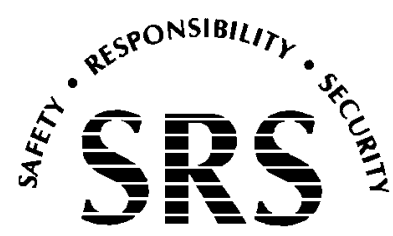

SAVANNAH RIVER SITE

Prepared for the U.S. Department of Energy Under

Contract Number DE-AC09-96SR18500 
This document was prepared in conjunction with work accomplished under Contract No. DE-AC09-96SR18500 with the U. S. Department of Energy.

\section{DISCLAIMER}

This report was prepared as an account of work sponsored by an agency of the United States Government. Neither the United States Government nor any agency thereof, nor any of their employees, makes any warranty, express or implied, or assumes any legal liability or responsibility for the accuracy, completeness, or usefulness of any information, apparatus, product or process disclosed, or represents that its use would not infringe privately owned rights. Reference herein to any specific commercial product, process or service by trade name, trademark, manufacturer, or otherwise does not necessarily constitute or imply its endorsement, recommendation, or favoring by the United States Government or any agency thereof. The views and opinions of authors expressed herein do not necessarily state or reflect those of the United States Government or any agency thereof.

This report has been reproduced directly from the best available copy.

Available for sale to the public, in paper, from: U.S. Department of Commerce, National Technical Information Service, 5285 Port Royal Road, Springfield, VA 22161, phone: (800) 553-6847, fax: (703) 605-6900

email: orders@ntis.fedworld.gov

online ordering: http://www.ntis.gov/help/index.asp

Available electronically at http://www.osti.gov/bridge

Available for a processing fee to U.S. Department of Energy and its contractors, in paper, from: U.S. Department of Energy, Office of Scientific and Technical Information, P.O. Box 62, Oak Ridge, TN 37831-0062,

phone: (865)576-8401,

fax: (865)576-5728

email: $\underline{\text { reports@ adonis.osti.gov }}$ 
Key Words: Soil Contaminant Immobilization, Apatite, Zero-Valent Iron, Actinium, Cobalt, Chromium, Mercury, Lead, Barium, Strontium, Thallium, Thorium, Uranium

Retention: Permanent

\title{
REDUCTION OF CONTAMINANT MOBILITY AT THE TNX OUTFALL DELTA THROUGH THE USE OF APATITE AND ZERO-VALENT IRON AS SOIL AMENDMENTS (U)
}

Daniel Kaplan, Anna Knox, and Cathy Coffey

\author{
Westinghouse Savannah River Company \\ Savannah River Technology Center \\ Aiken, SC 29808
}

SEPTEMBER 27, 2002 


\section{REVIEWS AND APPROVALS}
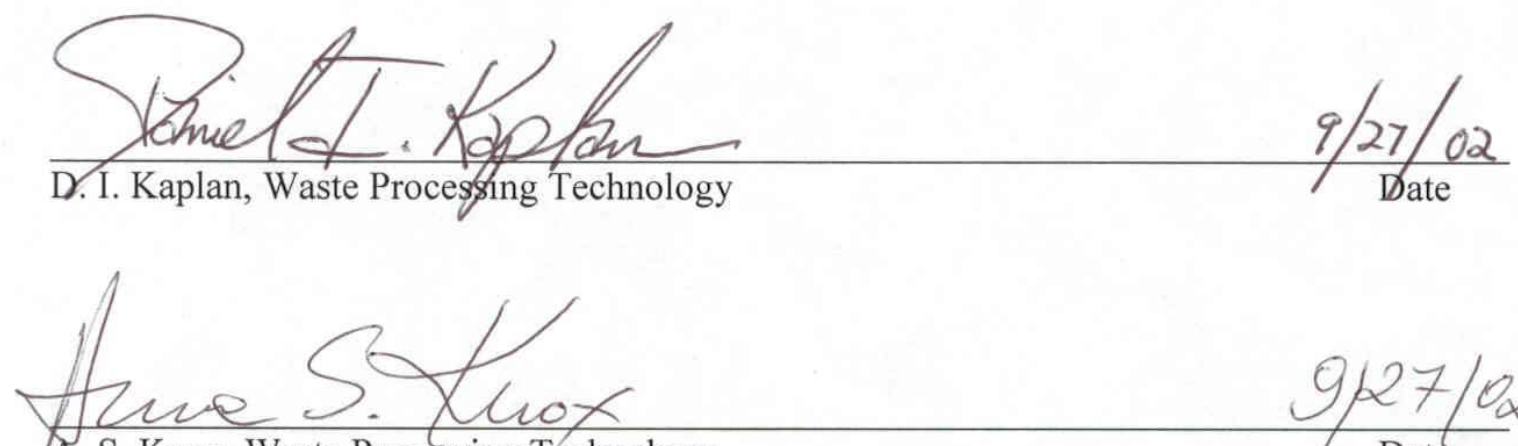

A. S. Knox, Waste Processing Technology

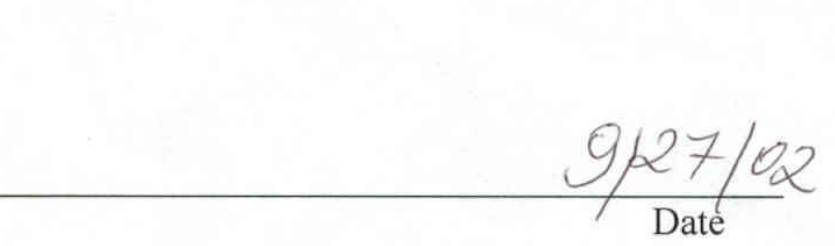

Upcophen

C. P. Coffey, Liquid/Waste Processing Date

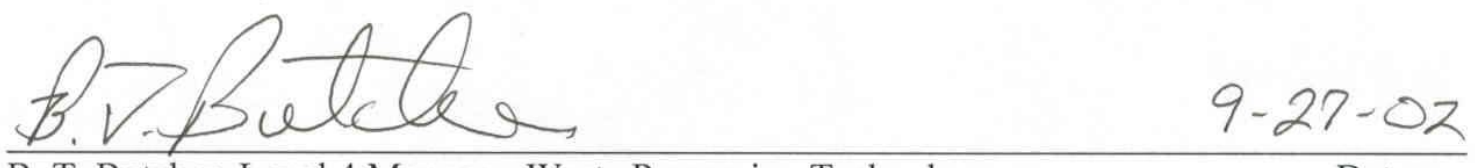

B. T. Butcher, Level 4 Manager, Waste Processing Technology Date

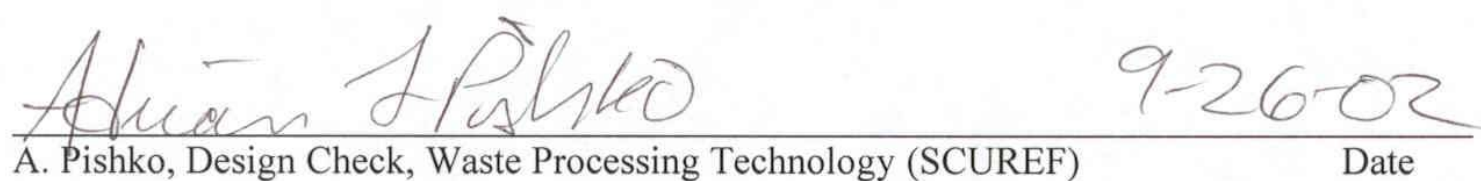

A. Pishko, Design Check, Waste Processing Technology (SCUREF) Date

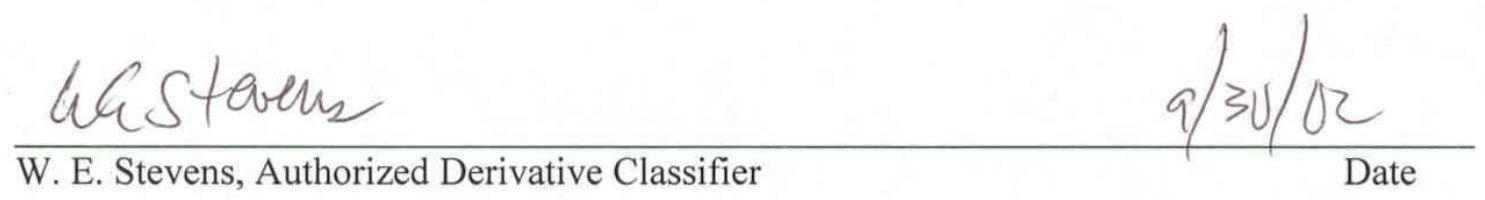




\section{TABLE OF CONTENTS}

List of Figures

List of Appendix Tables $\quad 6$

List of Acronyms

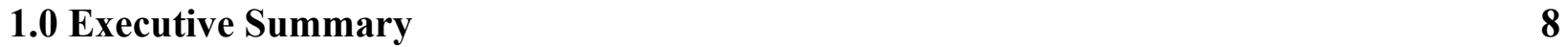

2.0 Introduction 9

2.1 Objective 12

2.2 Mechanisms by Which Apatite and Fe(0) Remove Contaminants from the Aqueous Phase

3.0 Materials and Methods $\quad 15$

$\begin{array}{lr}\text { 3.1 Materials } & 15\end{array}$

$\begin{array}{lr}3.2 \text { Methods } & 15\end{array}$

$\begin{array}{lr}\text { 3.2.1 Laboratory } & 15\end{array}$

$\begin{array}{lr}\text { 3.2.2 Statistics } & 16\end{array}$

$\begin{array}{ll}\text { 3.2.3 Sample Analysis and Quality Assurance } & 17\end{array}$

$\begin{array}{ll}\text { 4.0 Results and Discussion } & 17\end{array}$

4.1 Groundwater, Sediment, and Sediment Amendment Characterization 17

4.2 Pore Water Chemistry of the Flooded and the Wet/Dry-Cycled Control Treatments21

4.3 Pore Water Chemistry of the Flooded Treatments 23

4.4 Pore Water Chemistry of the Wet/Dry-Cycled Treatments 25

4.5 Sequential Extractions and "Potentially Leachable Source-Term Fraction" 29

4.6 Influence of Sediment Amendments on Calculated Source Term and Kd Values 38

5.0 Conclusions $\quad 41$

6.0 References $\quad 44$

7.0 Appendix A: Additional Data 47

8.0 Appendix B: Work Instructions for The Laboratory Study 55

\section{LIST OF FIGURES}

Figure 1. Topographical map of the TNX area showing the Outfall Delta, Inner Swamp, Outer

Swamp, Savannah River, and the X8 Drainage Ditch ........................................................ 10

Figure 2. Thorium Concentrations in the Surface Foot of Soil (data from WSRC 1999) ........... 11

Figure 3. Sequential Extraction of Sediment As, Ba, and Cr After 7-weeks of Contact Time ... 32

Figure 4. Sequential Extraction of Sediment $\mathrm{Co}$, Eu, and K After 7-weeks of Contact Time .... 33

Figure 5. Sequential Extraction of Sediment $\mathrm{Pb}, \mathrm{Se}$, and $\mathrm{Sr}$ After 7-weeks of Contact Time..... 34

Figure 6. Sequential Extraction of Sediment Th and U After 7-weeks of Contact Time............ 35 


\section{LIST OF APPENDIX TABLES}

Table 1. COC Concentrations in Naturally Occurring Apatite that were Unimpacted by

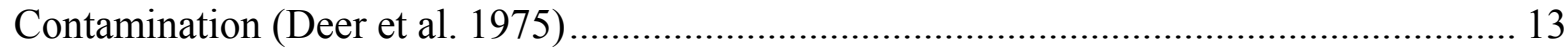

Table 2. Solubilities of Some Metal-Phosphate Phases........................................................... 14

Table 3. Chemical Composition of Uncontaminated Surface Water Collected from Near the

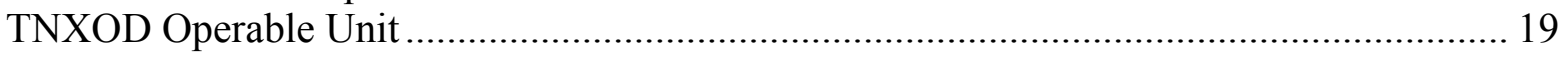

Table 4. Sediment and Sediment Amendment Properties .................................................. 20

Table 5. Comparison of the Pore Water Chemistry for the Flooded and the Wet/Dry-Cycled

Control Treatments: Eh, $\mathrm{O}_{2}, \mathrm{pH}$, and Electrical Conductivity ......................................... 21

Table 6. Comparison of the Pore Water Chemistry for the Flooded and the Wet/Dry Cycled

Control Treatments: Ancillary Constituent ...................................................................... 22

Table 7. Comparison of the Pore Water Chemistry for the Flooded and the Wet/Dry Cycled

Control Treatments: Constituents-of-Concern ................................................................ 22

Table 8. Water Chemistry of the Flooded Treatments: Eh, $\mathrm{O}_{2}, \mathrm{pH}$ and Electrical Conductivity 23

Table 9. Ancillary Constituent Pore Water Concentrations in the Wet/Dry Cycled Treatments:

$\mathrm{Eh}, \mathrm{O}_{2}, \mathrm{pH}$ and Electrical Conductivity ................................................................. 25

Table 10. Pore Water Chemical Concentrations of Ancillary Parameters in the Flooded

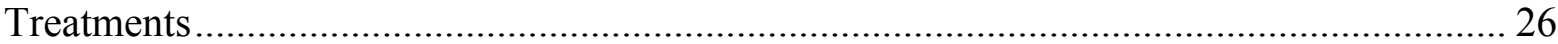

Table 11. Constituent-of-Concern Concentrations in the Pore Water of the Flooded Treatments

Table 12. Pore Water Chemical Concentrations of Ancillary Parameters in the Wet/Dry Cycling

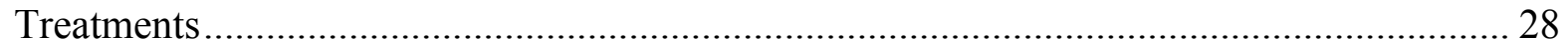

Table 13. Constituent-of-Concern Concentrations in the Pore Water of the Wet/Dry Cycled

Treatments............................................................................................................. 28

Table 14. Percentage of Constituent-of-Concern Associated with Strongly Sorbing Fraction (100

- Strongly Sorbing Fraction $=\%$ of Source Term That is Potentially Leachable; Equation 5)

Table 15. Percentage of Ancillary Constituents Associated with Strongly Sorbing Fraction (100

- Strongly Sorbing Fraction $=\%$ of Source Term That is Potentially Leachable) ................ 36

Table 16. Elemental Concentration and Sequential Fractionation of Apatite-NC...................... 37

Table 17. Influence of Sediment Amendments on $\mathrm{K}_{\mathrm{d}}$ Values for Contaminated Sediments ...... 40

Table 18. Summary of Sediment Amendments Effects on Various COC-Concentration

Parameters With Respect to the Controls ("L" = Significantly Lower, "H" = Significantly

Higher, Empty $=$ No Significant Difference). 


\section{LIST OF ACRONYMS}
AEC
bdl
CEC
COC
ICP-MS
ICP-AES
$\mathrm{K}_{\mathrm{d}}$
na
SRS
TNX OD

\author{
Anion Exchange Capacity \\ below detection limit \\ Cation Exchange Capacity \\ Constituent of Concern \\ Inductively Coupled Plasma - Mass Spectroscopy \\ Inductively Coupled Plasma - Atomic Emission Spectroscopy \\ Distribution Coefficient \\ not available \\ Savannah River Site \\ TNX Outfall Delta
}




\subsection{EXECUTI VE SUMMARY}

The TNX pilot-scale research facility released processed waste, containing high concentrations of several metals and radionuclides into an unlined seepage basin between 1958 and 1980. The contents of this basin have entered the nearby swamp, the TNX Outfall Delta (TNX OD), by subsurface and overland flow. A multi-facetted strategy has been proposed recently for mitigating contaminant migration at the site; it involves:

1) reducing overland flow of drainage, seep, and atmospheric water,

2) permitting a portion of the swamp (the Inner Swamp) to return to its wetter natural state, thereby creating conditions where natural organic matter would build up and the soil would become more chemically reduced, and

3) adding contaminant sequestering soil amendments to the most contaminated portions of the site.

The intent of this remediation strategy is not only to minimize contaminant leaching in a costeffective manner, but also to minimize harm to the sensitive TNX wetland ecosystem.

The objective of this study was aligned with the third facet of the multi-facetted strategy. Laboratory studies evaluated the effectiveness of adding soil amendments to increase the sequestration of numerous constituents of concern (COC's). The COC's include actinium, arsenic, cobalt, chromium, cesium, mercury, manganese, lead, radium, strontium, thallium, thorium, and uranium.

Two soil amendments were evaluated: zero-valent iron $[\mathrm{Fe}(0)]$, apatite, and a combination of both of them. Measurements were made of the COC concentrations in the amended soil leachate and also of how strongly the COC's were retained by the amended soils. The data showed that the simultaneous addition of $\mathrm{Fe}(0)$ and apatite to the TNX OD soil greatly stabilized most of the COC's. The amendments increased the $\mathrm{K}_{\mathrm{d}}$ values and decreased the potentially leachable fraction (i.e., the source term) for most COC's. One concern was the leaching of As (and possibly $\mathrm{Hg}$ ) from the apatite itself, however, this potential problem was offset by the addition of $\mathrm{Fe}(0)$. A second concern was that thallium showed only a moderate tendency to be retained by apatite and the removal mechanism is likely cation exchange, an ephemeral reaction.

Combined application of the two amendments to the site by surface broadcasting and/or into drilled shallow holes may provide an inexpensive and effective method to reduce the risk of exposure in a cost-effective and environmentally friendly manner for most, if not all, of the COC's. 


\subsection{INTRODU CTION}

The TNX pilot-scale research facility released processed waste into an unlined seepage basin between 1958 and 1980. The basin, referred to as the Old TNX Seepage Basin, was designed to contain wastewater until it could seep into the underlying soils. It was anticipated that the soil would then impede contaminant migration. The waste discharged to the Old TNX Seepage Basin included large quantities of $\mathrm{Cr}, \mathrm{Hg}, \mathrm{Na}, \mathrm{U}$, and Th. The basin contents have entered the nearby inner and outer swamps by subsurface and overland flow; the overland flow is the result of purposely breaching the basin walls and routinely overfilling the basin (Figure 1). Since the basin was closed, contaminant transport is believed to be occurring via two-phase and threephase (colloid-facilitated) transport in surface water. ${ }^{1}$ Among the observations in support of this latter transport mechanism are that: 1) strongly sorbing contaminants are found far from the point source, and 2) high concentrations of strongly sorbing contaminants are found far from the source in sunken depressions, where fine-grain material have accumulated (WSRC 1999). For example, the distribution of soil-Th at the TNX site is $>200$ - $\mathrm{m}$ from the point source, i.e., the discharge gully (Figure 2). Traditional two-phase contaminant transport modeling would predict that Th would not travel more than a couple meters from the point source.

A multi-facetted strategy recently proposed for mitigating contaminant migration at the TNX Outfall Delta (TNX OD) involves:

1) reducing overland flow of drainage, seep, and atmospheric water,

2) permitting the Inner Swamp to return to its wetter natural condition, thereby creating conditions where natural organic matter would build up and the soil would become more chemically reduced, and

3) adding contaminant sequestering soil amendments to the most contaminated portions of the site.

The intent of this remediation approach is not only to minimize contaminant leaching in a costeffective manner, but also to minimize adverse impact to the sensitive TNX wetland ecosystem.

Kaplan (2001) evaluated the second aspect of this remediation approach and concluded that converting the TNX OD site to a wetter, more reduced environment will likely decrease the mobility of $\mathrm{Pb}, \mathrm{Ra}$, and $\mathrm{U}$ and increase the mobility of $\mathrm{Th}$. It was concluded that by creating a more reducing environment and limiting the amount of overland flow that a large net decrease in overall dissolved radionuclide mobility would be achieved.

\footnotetext{
${ }^{1}$ Groundwater contaminant transport is traditionally described as taking place in a two-phase system: a mobile aqueous phase and an immobile solid phase. In a three-phase system, the third phase is a mobile solid phase, or colloidal phase. The net effect of a three-phase system as compared to a two-phase system is that strongly sorbing contaminants, such as actinium, lead, and thorium can move appreciably faster through sediment.
} 


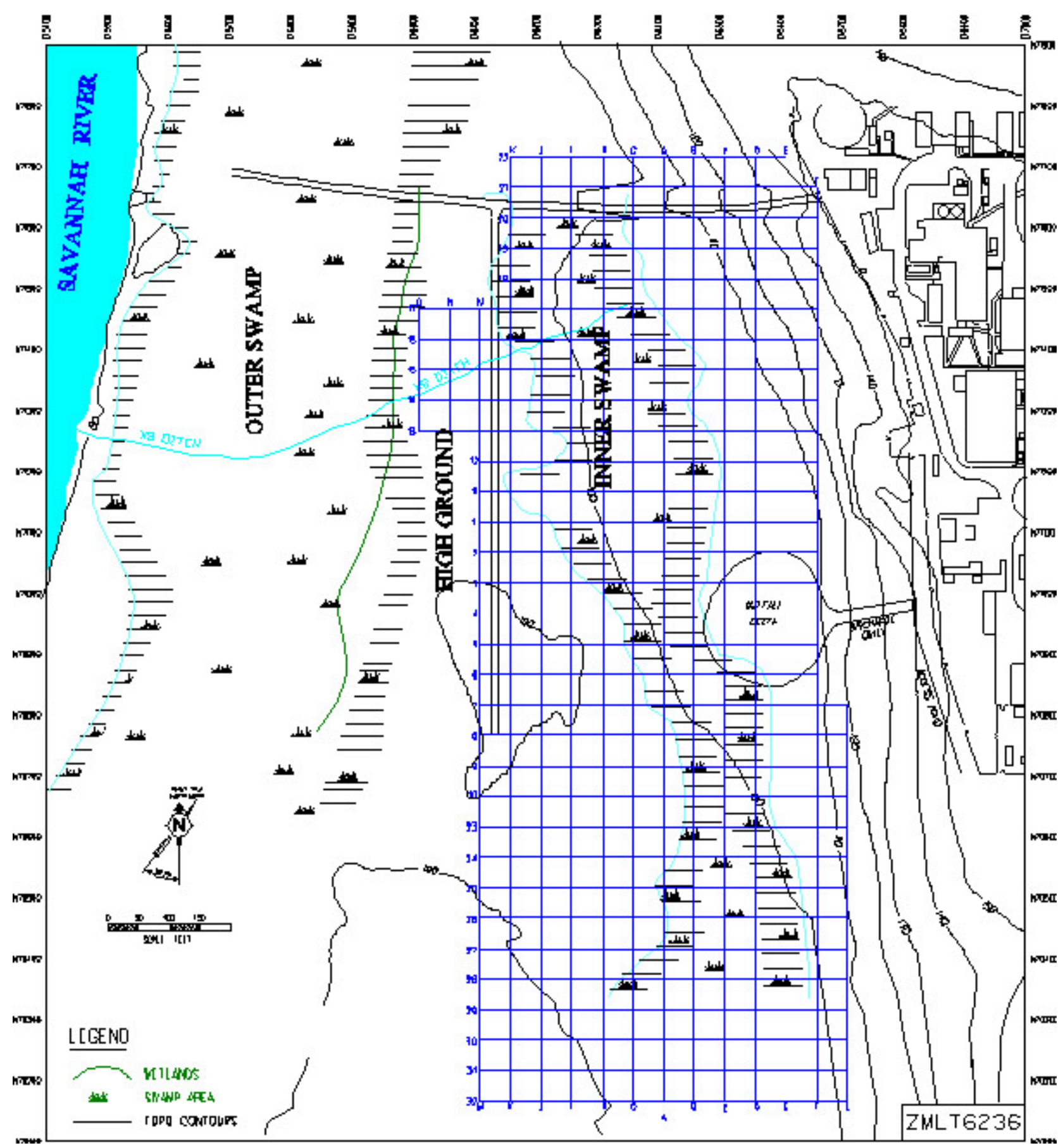

Figure 1. Topographical map of the TNX area showing the Outfall Delta, Inner Swamp, Outer Swamp, Savannah River, and the X8 Drainage Ditch 


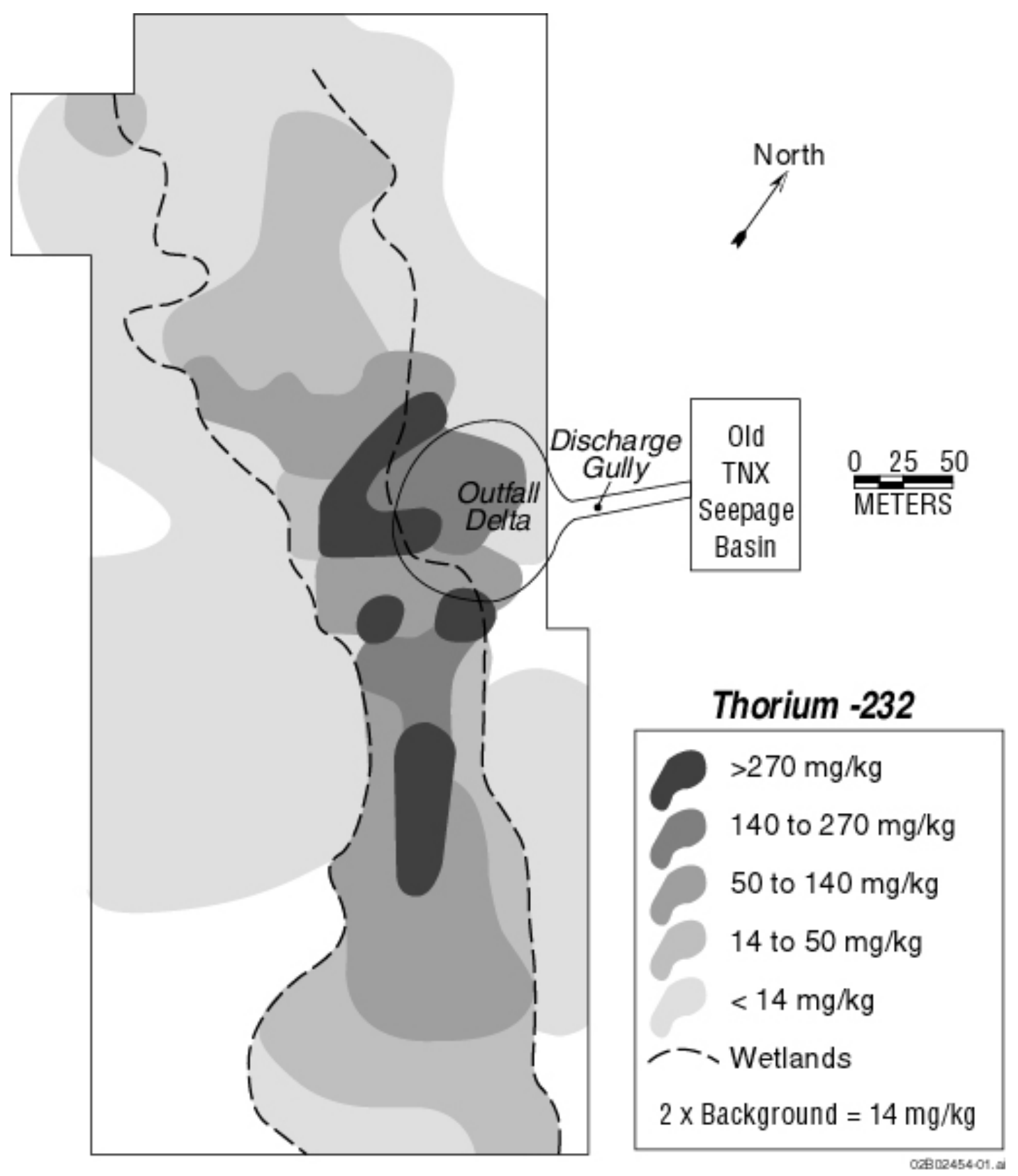

Figure 2. Thorium Concentrations in the Surface Foot of Soil (data from WSRC 1999) 


\subsection{OBJECTIVE}

The objective of this study was to conduct laboratory studies to evaluate the effectiveness of adding soil amendments to increase the sequestration of numerous constituents of concern (COC's). The COC's include Ac, As, Co, Cr, Cs, Hg, Mn, Pb, Ra, Sr, Tc, Tl, Th, and U. There are generally three main classes of soil amendments used to stabilize metal contaminants in soils. They are sulfide sources, phosphate sources, and reducing agents. We elected not to evaluate sulfide sources because one of the key COC's is mercury, and the addition of sulfates to mercury contaminated wetlands has been shown on the A1-Outfall located on the SRS to stimulate the microbiological conversion of elemental mercury to its more mobile and appreciably more hazardous methylated form. The two soil amendments we elected to evaluate were apatite, a calcium-phosphate mineral, and zero-valent iron, $\mathrm{Fe}(0)$. Apatite is a common subsurface and surface soil amendment for metal immobilization (reviewed at www.pimsnw.com), whereas $\mathrm{Fe}(0)$ is not as commonly used for surface soil applications as it is for subsurface permeable reactive barriers.

An additional objective of this study was to determine whether soil redox conditions would influence the sorption of the COC's by the soil amendments. The concern was whether the soil amendments were equally effective under constantly flooded and wet/dry cycled conditions. The TNX OD contains both types of conditions.

\subsection{MECHANIS MS BY WHICH APATITE AND Fe(0) REMOVE CONTAMINANTS FROM THE AQUEOUS PHASE}

Apatite removes solutes from the aqueous phase through three mechanisms: cation/anion exchange, isomorphic substitution, and precipitation. An example of the removal of lead via cation exchange onto apatite is presented in Equation 1:

$$
\mathrm{Ca}_{10}\left(\mathrm{PO}_{4}\right)_{6}(\mathrm{OH})_{2}(s)+x \mathrm{~Pb}^{2+}(a q) \rightarrow \mathrm{Ca}_{10-x} \mathrm{~Pb}_{x}\left(\mathrm{PO}_{4}\right)_{6}(\mathrm{OH})_{2}(s)+x \mathrm{Ca}^{2+}(a q) \text {. }
$$

This removal mechanism is the least desirable from the standpoint of soil stabilization because the bond between the contaminant and the apatite is relatively weak.

Isomorphic substitution is a process in which the contaminant substitutes for a calcium, phosphate, or hydroxide in the apatite structure. This removal mechanism is highly desirable because the contaminant becomes incorporated into the structure of the apatite. Isomorphic substitution is very common in apatite because its crystalline structure is very flexible, therefore several different elements can substitute into it. Calcium exists in apatite in 7-fold and 9-fold coordination. The 7-fold coordinated $\mathrm{Ca}$ ions are about $10 \%$ smaller than the 9 -fold coordinated ions. This difference in atomic size permits a rather large range of contaminants to substitute for $\mathrm{Ca}$, including the following COC's: Sr, Ra, Pb, Cs, Th, U(VI), and Cr(VI) (Deer et al. 1975).

Elements that can substitute for phosphate $(0.254 \mathrm{~nm}$ radius $)$ include $\mathrm{TcO}_{4}^{-}(0.268 \mathrm{~nm})$ and $\mathrm{CO}_{3}{ }^{2-}$ $(0.211 \mathrm{~nm})$. Finally, the hydroxyl anion $(0.153 \mathrm{~nm})$ can be substituted with $\mathrm{Br}^{-}(0.196 \mathrm{~nm}), \mathrm{Cl}^{-}$ $(0.181 \mathrm{~nm})$ and $\mathrm{F}^{-}(0.136 \mathrm{~nm})$. 
Concentrations of element impurities in natural apatite samples that were not impacted by contaminants are presented in Table 1. Previous studies have shown that biogenic apatite, while still associated with the living animal, contains very low concentrations of transition metals and actinides (Wright 1990). After deposition onto or into soils biogenic apatite (i.e., bone material) incorporates trace elements at concentration levels that are enriched by one to many orders of magnitude over the levels in the surrounding aqueous solutions (Wright 1990). This comparison of biogenic apatite in vivo to biogenic apatite exposed to natural water illustrates that apatite can act as a filter to retard the migration of trace elements in aqueous solution.

Table 1. COC Concentrations in Naturally Occurring Apatite that were Unimpacted by Contamination (Deer et al. 1975)

\begin{tabular}{lc}
\hline & Concentration in Apatite $(\mathrm{mg} / \mathrm{kg})$ \\
\hline $\mathrm{Sr}$ & 190,000 \\
$\mathrm{Ce}$ & 1840 \\
$\mathrm{~Pb}$ & 200 \\
$\mathrm{Cs}$ & 6 \\
$\mathrm{Th}$ & 117 \\
$\mathrm{U}$ & 227 \\
$\mathrm{Cr}$ & 760 \\
$\mathrm{CO}_{3}{ }^{2-}$ & 300,000 \\
\hline
\end{tabular}

The third mechanism by which apatite removes contaminants from the aqueous phase is by first dissolution (Equation 2), followed by formation of a precipitate with a metal (Equation 3)

$$
\begin{aligned}
& \mathrm{Ca}_{10}\left(\mathrm{PO}_{4}\right)_{6}(\mathrm{OH})_{2}(s)+14 \mathrm{H}^{+}(a q) \rightarrow 10 \mathrm{Ca}^{2+}(a q)+6 \mathrm{H}_{2} \mathrm{PO}_{4}^{-}(a q)+2 \mathrm{H}_{2} \mathrm{O}(a q) \\
& 10 \mathrm{M}^{2+}(a q)+6 \mathrm{H}_{2} \mathrm{PO}_{4}^{-}(a q)+2 \mathrm{H}_{2} \mathrm{O}(a q) \rightarrow \mathrm{M}_{10}\left(\mathrm{PO}_{4}\right)_{6}(\mathrm{OH})_{2}(s)+14 \mathrm{H}^{+}(a q)
\end{aligned}
$$

where $\mathrm{M}^{2+}$ represents a divalent cation. Phosphate-metal precipitates are typically very stable (Table 2). Another important mechanism by which apatite induces precipitation of metals is through the formation of carbonate phases. As Equation 2 shows, apatite dissolution results in an increased $\mathrm{pH}$, which in turn promotes an increase in carbonate concentrations. These carbonates can form precipitates with several metals. In almost all cases though, carbonate precipitates are more soluble than phosphate precipitates. 
Table 2. Solubilities of Some Metal-Phosphate Phases

\begin{tabular}{cc}
\hline Mineral Phase & Solubility Product $\left(\log \mathrm{K}_{\mathrm{sp}}\right)$ \\
\hline $\mathrm{Pb}_{5}\left(\mathrm{PO}_{4}\right)_{3}(\mathrm{OH}, \mathrm{Cl})$ & -76.5 \\
$\mathrm{Sr}_{5}\left(\mathrm{PO}_{4}\right)_{3}(\mathrm{OH})$ & -51.3 \\
$\mathrm{Zn}_{3}\left(\mathrm{PO}_{4}\right)_{3}$ & -35.3 \\
$\mathrm{Cd}_{3}\left(\mathrm{PO}_{4}\right)_{3}$ & -32.6 \\
$\left.\mathrm{Pu}_{3} \mathrm{PO}_{4}\right)$ & -24.4 \\
Quartz $\left(\mathrm{SiO}_{2}\right)$ & -4 \\
\hline
\end{tabular}

The final soil amendment evaluated in this study was $\mathrm{Fe}(0)$. $\mathrm{Fe}(0)$ removes metals from the aqueous phase by three primary processes: reductive precipitation (by $\mathrm{Fe}(0)$ or $\mathrm{Fe}(\mathrm{II})$ ), coprecipitation with $\mathrm{Fe}(\mathrm{II} / \mathrm{III})$, and metal sorption by $\mathrm{Fe}(0)$-originating, $\mathrm{Fe}(\mathrm{II} / \mathrm{III})$-oxyhydroxides. Reductive precipitation involves the transfer of electrons from $\mathrm{Fe}(0)$ to a $\mathrm{COC}$ that is less soluble in the reduced from than in the oxidized form. Common contaminants that can be removed from the aqueous phase in this manner are $\mathrm{As}, \mathrm{Cr}, \mathrm{Hg}, \mathrm{Mo}, \mathrm{Se}, \mathrm{Tc}$, and $\mathrm{U}$. For example, the reductive precipitation of $\mathrm{Cr}(\mathrm{VI})$ can be described by Equation 4:

$$
\mathrm{CrO}_{4}{ }^{2-}(a q)+1.5 \mathrm{Fe}^{0}(s)+5 \mathrm{H}^{+}(a q)=\mathrm{Cr}(\mathrm{OH})_{3}(s)+\mathrm{H}_{2} \mathrm{O}(a q)+1.5 \mathrm{Fe}^{2+}(a q) .
$$

In this example, $\mathrm{CrO}_{4}{ }^{2-}$ is both more mobile and toxic than $\mathrm{Cr}(\mathrm{OH})_{3}$, which is a solid phase.

As Equation 4 shows, $\mathrm{Fe}^{2+}$ is produced and acidity $\left(\mathrm{H}^{+}\right)$is consumed. Both of these changes are conducive to the formation of $\mathrm{Fe}$ (II/III)-oxyhydroxides. If other metals are present, they may coprecipitate with the $\mathrm{Fe}(\mathrm{II} / \mathrm{III})$-oxyhydroxide. Chrome removal by $\mathrm{Fe}(0)$ is believed to be primarily through this reaction, whereby $\mathrm{Cr} / \mathrm{Fe}(\mathrm{OH})_{3}$ solid solutions are formed (Eary and Rai 1987, Sass and Rai 1987).

$\mathrm{Fe}(0)$ can remove aqueous contaminants by first oxidizing to form $\mathrm{Fe}(\mathrm{II} / \mathrm{III})$-oxyhydroxides, which then can act as an adsorbent. The Fe(II/III)-oxyhydroxides increase the sorption capacity of the system. Contaminant removal in this manner is the least desirable of the three removal mechanisms due to the weak nature of the bond between the contaminant and the Fe(II/III)oxyhydroxide. 


\subsection{MATERIA LS AND METHODS}

A detailed description of the laboratory procedure used in this study is presented in Appendix B: Work Instructions for The Laboratory Study. The following is a brief synopsis.

\subsection{MATERIALS}

The sediment used in this study came from coordinate B-5 in the TNX OD study site (Figure 1). This sediment was used because it had relatively high contaminant concentrations, yet, based on analytical results, was not classified as either hazardous or radioactive. The sediment sample was collected from the top $15 \mathrm{~cm}$, but did not include the surface organic mat, i.e., the $\mathrm{O}$ soil horizon. Granular Fe(0) (Peerless Supply, Columbus, $\mathrm{OH}$ ) and two forms of apatite were used as sediment amendments. One of the apatite minerals, Apatite-NC, came from a mine in North Carolina (Texas Gulf Mining, Aurora, NC). The second apatite, Apatite-II, is of a biogenic origin: ground fish bones (www.pimsnw.com; PIMS-NW, Richland, WA). Both forms of apatite have been used at several metal-contaminated remediation sites. However, these forms of apatite differ significantly. Apatite-II is appreciably more soluble and therefore would be effective for immediately stabilizing contaminants at a site. Additionally, Apatite-II has much lower concentrations of impurities that may potentially leach into the surrounding groundwater. Apatite-II has only recently been made commercially available, but it has been field tested at a number of sites, including:

- $\quad$ Success Mine, ID ( $\mathrm{Zn}, \mathrm{Pb}$, and $\mathrm{Cd})$

- Oak Ridge National Laboratory, $\mathrm{TN}\left(\mathrm{U}\right.$ and $\left.\mathrm{NO}_{3}{ }^{-}\right)$

- Camp Stanley, TX $(\mathrm{Pb})$

- Los Alamos National Laboratory, NM (U)

- Los Alamos National Laboratory, $\mathrm{NM}\left(\mathrm{Pu}, \mathrm{Am}\right.$ and $\left.\mathrm{NO}_{3}{ }^{-}\right)$, and

- Independence Mine ( $\mathrm{Zn}, \mathrm{Pb}$, and $\mathrm{Cd})$.

The water used in this study was collected from a surface stream located $\sim 1000 \mathrm{~m}$ north of the northern boundary of the operable unit. The water was passed through a $0.45-\mu \mathrm{m}$ filter and stored at $4{ }^{\circ} \mathrm{C}$ when not in use.

\subsection{METHODS}

\subsubsection{Laboratory}

The experimental design was a randomized block design with 3 replicates, 4 amendments (control, $\mathrm{Fe}(0)$, Apatite-NC, and $\mathrm{Fe}(0)+$ Apatite-NC) and 2 moisture conditions (flooded and wet/dry-cycled, to simulate cyclic rain events), for a total of 24 treatments. For the flooded treatments, 15-g of B-5 sediment, 0.5-g of appropriate amendment (1-g total for the $\mathrm{Fe}(0)+$ 
Apatite-NC treatment), and 25-mL of uncontaminated surface water (collected from just north of the study site) were added to 50-mL tubes. The tubes were left on a platform shaker for 7 weeks before separating the solids and liquids for chemical characterization.

For the wet/dry-cycled treatments, 12 disposable filtration units were used. These $115-\mathrm{mL}$ Plexiglas containers consisted of two chambers separated by a $0.45-\mu \mathrm{m}$ filter membrane. $15-\mathrm{g}$ of sediment and $0.5-\mathrm{g}$ of amendment were mixed and then placed on the filter. $25-\mathrm{mL}$ of the uncontaminated surface water was added on the Friday of each week. Most of the water would remain above the filter until the following Monday, when it was suction vacuumed down through the filter. Twice a day between Monday and Friday, the sediments were mixed with a spatula to facilitate sediment drying. Generally, the sediments were completely air dried by Wednesday. On the next Friday, the leachate would be poured into a 25-mL graduated column and brought up to volume using uncontaminated surface water. Typically, 7-mL of water was required to bring the volume up to $25-\mathrm{mL}$. This $25-\mathrm{mL}$ solution would then be poured onto the amended sediment. The one-week wet/dry cycle was repeated six times before terminating the experiment by collecting the aqueous phase from the lower chamber of the filtration unit and permitting the sediment to air dry on the filter.

On the day the experiment was terminated, $\mathrm{pH}$, Eh (a measure of the redox status), dissolved $\mathrm{O}_{2}$, and electrical conductivity (a measure of the total concentration of ions in solution) were measured in the solutions. The solutions were then acidified and analyzed for cations by ICPMS and ICP-AES. ICP-MS was used to measure As, $\mathrm{Co}, \mathrm{Cr}, \mathrm{Hg}, \mathrm{Sr}$, Th, and $\mathrm{U}$, as several ancillary parameters. ICP-AES was used to measure $\mathrm{Mn}$ and $\mathrm{Fe}$, and several ancillary parameters. Of the COC's, only Ac, Ra, and Tl were below detection limit. For these COC's the geochemical behavior of $\mathrm{Ce}, \mathrm{Ba}$, and $\mathrm{K}$ were monitored and used as analogs for $\mathrm{Ac}, \mathrm{Ra}$, and $\mathrm{Tl}$, respectively.

The sediments from the flooded treatments were subjected to a sequential extraction procedure. The details of this procedure are included in Appendix B. Briefly, a subsample of the treated sediments was extracted by a series of solutions that targeted operationally defined contaminant fractions. The extracts were increasingly aggressive at removing contaminants. The resulting five fractions were the exchangeable, amorphous Fe-oxide, organic/sulfide, crystalline Fe-oxide, and structural fractions. A description of what these fractions constitute and the details of the procedure are provided in Tessier et al. (1979) and Hall et al. (1996). The resulting extract solutions were acidified for sample preservation and characterized by ICP-MS and ICP-AES.

\subsubsection{Statistics}

There were two types of statistics used in this study. The first was the $t$-test to compare two treatment means. The second was Dunett's test to compare all treatment means with a control (Winer 1971). Briefly, there are $k$ treatments, and $k-1$ comparisons with the Control. Rather than setting a level of significance equal to $\alpha$ for each of the tests, this test sets a level equal to $\alpha$ for the collection of the $k-1$ decisions, considered as a single decision summarizing the outcomes. Since each of the tests uses the same information on the control condition and a common estimate of experimental error, the tests are not independent. What this means is that 
the variance of all the means are pooled together. Dunett's test is also a two-tailed test, meaning that it will identify means that are significantly greater and smaller than the control.

\subsubsection{Sample An alysis and Quality Assurance}

All work conducted in this study followed Standard QA practices described in the WSRC QA Manual 1Q. Eh, $\mathrm{pH}$, electrical conductivity, dissolved $\mathrm{O}_{2}$, and all sediment characterization measurements were made by SRTC personnel following standard procedures described in detail by Sparks (1996). Blanks and spikes were included where technically appropriate (e.g., there is no blank control for a $\mathrm{pH}$ measurement). ICP-MS, ICP-AES, and total inorganic and total organic $\mathrm{C}$ analyses were conducted by the Chemical Analysis Laboratory, University of Georgia. This EPA-certified lab provided us with the results of blank and spike controls. Data that were outside of EPA guidelines are not included in this report. There were analytical interferences with some of the ICP-MS Hg data and instrument problems with the ICP-AES Mg data; none of these compromised data are included in the report.

The lab notebook used for this study is WSRC-NB-2001-00133.

\subsection{RESULTS AND DISCUSSION}

\subsection{GROUNDW ATER, SEDIMENT, AND SEDIMENT AMENDMENT CHARACTERIZATION}

The chemical composition of the surface water used through out this study is presented in Table 3. The acidity and high organic $\mathrm{C}$ concentration is characteristic of wetland surface waters. The water contains low concentrations of all the COC's.

Chemical and physical characterization of the B-5 sediment used in this study is presented in Table 4. The textural analysis (sand-silt-clay) indicates that it's a loamy sand. Its low $\mathrm{pH}, 4.53$, and high organic matter content, $1427 \mathrm{mg} / \mathrm{kg}$, are typical of wetland sediments of this area. For purposes of comparison, some elemental concentration data of a background sediment collected just north of the operable unit are included in the table. Among the COC's that are appreciably greater than the background are $\mathrm{As}, \mathrm{Co}, \mathrm{Cr}, \mathrm{Hg}, \mathrm{Pb}$, and $\mathrm{Th}$. The $\mathrm{U}$ concentration in the $\mathrm{B}-5$ sediment was surprisingly low, essentially the same as in the background sediment.

The $\mathrm{Fe}(0)$ contained especially high concentrations of $\mathrm{As}, \mathrm{Co}, \mathrm{Cr}$, and $\mathrm{Cu}$. It is important to note that some portion of these elements may be leachable, their fate in leach tests must be monitored, the subject of Sections 4.3 and 4.4.

There were two sources of apatite used in this study. Initially, only the mined Apatite-NC was used. But once the elemental data in Table 4 became available, revealing that it contained extremely high concentrations of $\mathrm{As}, \mathrm{Cr}, \mathrm{Hg}, \mathrm{Pb}, \mathrm{Sr}$, and $\mathrm{U}$, a second biogenic source of apatite, 
Apatite II, was included in the experiment. As expected the Apatite-II generally contained appreciably lower concentrations of the COC's than the Apatite-NC.

The $\mathrm{Sr}$ reported in Table 4 is the stable isotope, not the radioactive isotopes; thus, its high concentration in the Apatite-II is not, in itself, of great concern. The same is in principal true of the $U$ concentrations reported in Table 4 (stable ${ }^{238} \mathrm{U}$ accounts for $>99 \%$ of the naturally occurring U). Although these are not the isotopes of concern, their elevated concentrations may have some adverse effects on the targeted isotopes. For example, they may promote ion exchange, thereby enhancing the desorption of the higher risk isotope.

High concentrations of $\mathrm{COC}$ in the Apatite-NC were expected because it is well known that these elements become concentrated into the structure of the apatite mineral (see review presented in Section 2.2). Metal concentration in apatite is the very mechanism that this technology attempts to capitalize on. So in a sense, this data provides part of the data required for a natural analog study that shows that the COC's can be concentrated in the minerals to levels several orders of magnitude greater than that in the uncontaminated natural waters surrounding it. The second part of a natural analog study would need to show whether these COC's remain strongly associated to the apatite. This will be discussed later in the report in association with sequential extraction data of the Apatite-NC (Section 4.5), and leachate COC data from the Apatite-NC (Sections 4.2 and 4.3). 
Table 3. Chemical Composition of Uncontaminated Surface Water Collected from Near the TNXOD Operable Unit

\begin{tabular}{lcc|lcc}
\hline Constituent & $\begin{array}{c}\text { Concentration } \\
(\mu \mathrm{g} / \mathrm{L})\end{array}$ & $\begin{array}{c}\text { Concentration } \\
(\mathrm{mM})\end{array}$ & Constituent & $\begin{array}{c}\text { Concentration } \\
(\mu \mathrm{g} / \mathrm{L})\end{array}$ & $\begin{array}{c}\text { Concentration } \\
(\mathrm{mM})\end{array}$ \\
\hline $\mathrm{pH}$ & $5.1($ unitless $)$ & & $\mathrm{Na}$ & 357.28 & 0.016 \\
$\mathrm{Al}$ & 9.12 & 0.00034 & $\mathrm{Ni}$ & 1.29 & $2.2 \mathrm{E}-05$ \\
$\mathrm{As}$ & 0.18 & & $\mathrm{Se}$ & $<0.61$ & $<0.0013$ \\
$\mathrm{Ba}$ & 64.87 & 0.0005 & $\mathrm{Si}$ & 4395 & 0.1565 \\
$\mathrm{Ca}$ & 3850 & 0.0962 & $\mathrm{Sm}$ & 0.026 & $1.74 \mathrm{E}-07$ \\
$\mathrm{Ce}$ & 0.087 & $6.2 \mathrm{E}-07$ & $\mathrm{Sr}$ & 33.98 & 0.00039 \\
$\mathrm{Co}$ & 0.065 & $1.1 \mathrm{E}-06$ & $\mathrm{Th}$ & 0.013 & $5.69 \mathrm{E}-08$ \\
$\mathrm{Cr}$ & 0.92 & & $\mathrm{Tl}$ & 0.055 & $2.69 \mathrm{E}-07$ \\
$\mathrm{Cs}$ & 0.052 & $3.9 \mathrm{E}-07$ & $\mathrm{U}$ & $<0.01$ & $<4.20 \mathrm{E}-04$ \\
$\mathrm{Cu}$ & $<0.13$ & & Zn & 12.53 & 0.00019 \\
$\mathrm{Eu}$ & 0.016 & $1 \mathrm{E}-07$ & Chloride & 2061 & 0.0598 \\
$\mathrm{Fe}$ & 99.3662 & 0.00178 & Nitrate & 186 & 0.003 \\
$\mathrm{Hg}$ & 0.076 & $3.8 \mathrm{E}-07$ & Phosphate & $<100$ & $<0.0011$ \\
$\mathrm{~K}$ & 229.15 & 0.0058 & Nitrite & $<100$ & $<0.022$ \\
$\mathrm{La}$ & 0.056 & $4 \mathrm{E}-07$ & Sulfate & 13690 & 0.214 \\
$\mathrm{Li}$ & 0.55 & $7.9 \mathrm{E}-05$ & Inorganic C & $<100$ & $<0.0083$ \\
$\mathrm{Mg}$ & 1117.89 & 0.046 & Organic C & 6051 & 0.504 \\
$\mathrm{Mn}$ & 57.9 & 0.001 & Summation of Cations & 0.325 \\
& & & Summation of Anions & 0.277 \\
\hline
\end{tabular}

Surface water sample collected about $1000 \mathrm{~m}$ north of the northern boundary of the operable unit. 
WSRC-TR-2002-00370, Rev. 0

Page 20

Table 4. Sediment and Sediment Amendment Properties

\begin{tabular}{|c|c|c|c|c|c|c|c|}
\hline & Units & $\begin{array}{r}\text { B-5 } \\
\text { Sediment }\end{array}$ & $\begin{array}{r}\text { Background } \\
\text { (a) }\end{array}$ & Apatite-NC & Apatite-II & Metallic Fe & $\begin{array}{l}\text { Instrument or } \\
\text { Method }^{(b)}\end{array}$ \\
\hline$\overline{\text { As }}$ & $\mu \mathrm{g} / \mathrm{kg}$ & 9221 & 1520 & 29396 & 1078 & 6155 & ICP-MS \\
\hline $\mathrm{Ba}$ & $\mu \mathrm{g} / \mathrm{kg}$ & 147711 & 21970 & 20416 & 9235 & 1843 & ICP-MS \\
\hline $\mathrm{Cd}$ & $\mu \mathrm{g} / \mathrm{kg}$ & $\mathrm{na}^{(\mathrm{c})}$ & 24830 & na & 200 & 380 & ICP-MS \\
\hline $\mathrm{Ce}$ & $\mu \mathrm{g} / \mathrm{kg}$ & na & 4850 & na & 17 & 209 & ICP-MS \\
\hline Co & $\mu \mathrm{g} / \mathrm{kg}$ & 3664 & 663 & 897 & 36 & 3459 & ICP-MS \\
\hline $\mathrm{Cr}$ & $\mu \mathrm{g} / \mathrm{kg}$ & 38459 & 2820 & 76275 & 166 & 72956 & ICP-MS \\
\hline $\mathrm{Cu}$ & $\mu \mathrm{g} / \mathrm{kg}$ & na & 2190 & $\mathrm{na}^{(\mathrm{b})}$ & 4859 & 117632 & ICP-MS \\
\hline $\mathrm{Eu}$ & $\mu \mathrm{g} / \mathrm{kg}$ & 981 & na & 789 & bdl & bdl & ICP-MS \\
\hline $\mathrm{Hg}$ & $\mu \mathrm{g} / \mathrm{kg}$ & 3507 & 22 & 5320 & 298 & 229 & ICP-MS \\
\hline $\mathrm{Pb}$ & $\mu \mathrm{g} / \mathrm{kg}$ & 35338 & 12191 & 17634 & 398 & 1292 & ICP-MS \\
\hline $\mathrm{Sr}$ & $\mu \mathrm{g} / \mathrm{kg}$ & na & 1460 & 508 & 40905 & 1840 & ICP-MS \\
\hline Th & $\mu \mathrm{g} / \mathrm{kg}$ & 11501 & 2320 & 844 & bdl & bdl & ICP-MS \\
\hline $\mathrm{U}$ & $\mu \mathrm{g} / \mathrm{kg}$ & 2663 & 3780 & 62103 & 407 & bdl & ICP-MS \\
\hline $\mathrm{Al}$ & $\mathrm{mg} / \mathrm{kg}$ & 2620 & 1915 & 1382 & 8 & 5 & ICP-AES \\
\hline $\mathrm{Ca}$ & $\mathrm{mg} / \mathrm{kg}$ & na & 78.9 & $>103443$ & $>123069$ & 905 & ICP-AES \\
\hline $\mathrm{Fe}$ & $\mathrm{mg} / \mathrm{kg}$ & 16673 & 889 & 2627 & 28 & 88963 & ICP-AES \\
\hline $\mathrm{K}$ & $\mathrm{mg} / \mathrm{kg}$ & 646 & 87 & 341 & 1928 & bdl & ICP-AES \\
\hline $\mathrm{Mn}$ & $\mathrm{mg} / \mathrm{kg}$ & 135 & 84 & 17 & bdl & 436 & ICP-AES \\
\hline $\mathrm{Mg}$ & $\mathrm{mg} / \mathrm{kg}$ & na & 75 & 1851 & 37480 & 681 & ICP-AES \\
\hline $\mathrm{Na}$ & $\mathrm{mg} / \mathrm{kg}$ & na & 25 & 4831 & 8722 & 221 & ICP-AES \\
\hline $\mathrm{P}$ & $\mathrm{mg} / \mathrm{kg}$ & 606 & 787 & $>101013$ & $>163823$ & 1307 & ICP-AES \\
\hline $\mathrm{Se}$ & $\mathrm{mg} / \mathrm{kg}$ & 357 & 212 & 156 & 215 & 220 & ICP-AES \\
\hline $\mathrm{pH}$ & unitless & 4.53 & 4.16 & 7.93 & na & na & 1:1 Solid/Liq \\
\hline Sand-Silt-Clay & wt- $\%$ & $82-13-5$ & $80-14-6$ & $98-2-0$ & na & $68-32-0$ & Pipette \\
\hline Organic C & $\mathrm{mg} / \mathrm{kg}$ & 1427 & 1395 & na & na & na & Wet digestion \\
\hline CEC & $\mathrm{cmol}_{(+)} / \mathrm{kg}$ & 7.33 & 4.75 & na & na & na & $\mathrm{K}^{+}$exchange \\
\hline $\mathrm{AEC}$ & $\mathrm{cmol}_{(-)} / \mathrm{kg}$ & 1.11 & 1.56 & na & na & na & $\mathrm{NO}_{3}{ }^{-}$exchange \\
\hline Fe-oxides & $\% \mathrm{Fe}_{2} \mathrm{O}_{3}$ & 0.09 & na & na & na & na & Dithionite digestable \\
\hline
\end{tabular}

(a) Kaplan et al. (2000), Sediment 101 is a surface sediment collect just north of the operable unit.

(b) Elemental composition was determined by first digesting in concentrated $\mathrm{H}_{2} \mathrm{SO}_{4}, \mathrm{HNO}_{3}$, and $\mathrm{HCl}$ solution using the Star 6 System $^{\circledR}$ and then the digest was analyzed by ICP-MS and ICP-AES; $\mathrm{pH}$ by sediment/water equilibration (Thomas 1996); Organic C by unheated potassium dichromate method (Nelson and Sommers 1996; Cation exchange capacity (CEC) and anion exchange capacity (AEC) were determined by exchange with $\mathrm{K}$ and $\mathrm{NO}_{3}{ }^{-}$ions on sediments with were not $\mathrm{pH}$ adjusted (Sumner and Miller 1996); Particle size distribution, sand-siltclay, by the micropipette method (Miller and Miller 1987).

(c) $\mathrm{na}=$ not analyzed; bdl = below detection limit 


\subsection{PORE WAT ER CHEMISTRY OF THE FLOODED AND THE WET/DRY-CYCLED CONTROL TREATMENTS}

As mentioned in the Material and Methods section, the experimental design of this study was:

[4 sediment amendments (Control, Apatite-NC, Apatite-NC + $\mathrm{Fe}(0), \mathrm{Fe}(0)) \times 2$ moisture regimes (Flooded, Wet/Dry cycled) x 3 replicates $]+[1$ sediment amendment (Apatite-II) $\mathrm{x} 1$ moisture regime (Flooded) x 3 replicates].

The Apatite-II treatments were added later to the study.

Pore water chemistry of the control treatments (the treatments that did not receive any sediment amendment) will be discussed in this section. In addition to presenting the COC's concentration, a number of ancillary aqueous chemistry parameters will also be presented. These parameters provide important insight into the likely mechanisms by which the COC's are removed from the aqueous phase.

The pore waters from the Flooded and the Wet/Dry-Cycled treatments differed significantly. Comparing the controls, the Flooded samples had significantly lower Eh and dissolved $\mathrm{O}_{2}$ levels, and higher $\mathrm{pH}$ and electrical conductivity levels (Table 5). These are rather profound differences and are surprising given that the only difference between them is the duration that the pore water was in contact with the sediment. It underscores the importance of including the moisture regime variable in the test, because both saturated and intermittently saturated sediments are likely to exist at the site. The Flooded treatment generally had higher ancillary constituent (Table 6) and COC (Table 7) pore water concentrations than the Wet/Dry-Cycled treatment. The longer contact time between the surface water and the sediment in the Flooded treatments permitted more chemical changes to occur, including reduction and $\mathrm{COC}$ desorption. Both reactions would generally result in greater elemental pore water concentrations.

Table 5. Comparison of the Pore Water Chemistry for the Flooded and the Wet/Dry-Cycled Control Treatments: Eh, $\mathrm{O}_{2}, \mathrm{pH}$, and Electrical Conductivity

\begin{tabular}{|c|c|c|c|c|c|}
\hline & & $\begin{array}{c}\mathrm{Eh} \\
(\mathrm{mV})\end{array}$ & $\begin{array}{c}\mathrm{O}_{2} \\
(\mathrm{ppm})\end{array}$ & $\mathrm{pH}$ & $\begin{array}{l}\text { Conductivity } \\
(\mu \mathrm{S} / \mathrm{cm})\end{array}$ \\
\hline Control - Flooded & $\begin{array}{c}\text { avg } \\
\text { (stdev) }\end{array}$ & $\begin{array}{r}-145 \\
(23)\end{array}$ & $\begin{array}{r}0.10 \\
(0.06)\end{array}$ & $\begin{array}{l}5.8 * \\
(0.2)\end{array}$ & $\begin{array}{l}505 * \\
(16)\end{array}$ \\
\hline Control - Wet/Dry & $\begin{array}{c}\text { avg } \\
\text { (stdev) }\end{array}$ & $\begin{array}{l}287 * \\
(11)\end{array}$ & $\begin{array}{r}5.5 * \\
(0.5)\end{array}$ & $\begin{array}{r}4.5 \\
(0.1) \\
\end{array}$ & $\begin{array}{r}263 \\
(16) \\
\end{array}$ \\
\hline
\end{tabular}

* Indicates a significantly greater mean $(\mathrm{P} \leq 0.05)$ between the Flooded and Wet/Dry Cycled Treatments. 
Table 6. Comparison of the Pore Water Chemistry for the Flooded and the Wet/Dry Cycled Control Treatments: Ancillary Constituent

\begin{tabular}{|c|c|c|c|c|c|c|c|c|c|c|c|}
\hline & & $\begin{array}{c}\mathrm{Al} \\
(\mathrm{ppb})\end{array}$ & $\begin{array}{c}\mathrm{Ca} \\
(\mathrm{ppm})\end{array}$ & $\begin{array}{c}\mathrm{Fe} \\
(\mathrm{ppm})\end{array}$ & $\begin{array}{c}\mathrm{Mg} \\
(\mathrm{ppm})\end{array}$ & $\begin{array}{c}\mathrm{Mn} \\
(\mathrm{ppm})\end{array}$ & $\begin{array}{c}\mathrm{Na} \\
(\mathrm{ppm})\end{array}$ & $\begin{array}{c}\mathrm{P} \\
(\mathrm{ppm})\end{array}$ & $\begin{array}{c}\mathrm{Se} \\
(\mathrm{ppm})\end{array}$ & $\begin{array}{c}\mathrm{TIC} \\
(\mathrm{ppm})\end{array}$ & $\begin{array}{c}\text { TOC } \\
(\mathrm{ppm})\end{array}$ \\
\hline $\begin{array}{l}\text { Control - } \\
\text { Flooded }\end{array}$ & $\begin{array}{r}\text { avg } \\
\text { (stdev) }\end{array}$ & $\begin{array}{l}233.83 \\
(26.20)\end{array}$ & $\begin{array}{l}12.44 * \\
(1.35)\end{array}$ & $\begin{array}{l}177.10 * \\
(35.98)\end{array}$ & $\begin{array}{c}7.39 * \\
(1.01)\end{array}$ & $\begin{array}{l}5.42 * \\
(1.14)\end{array}$ & $\begin{array}{r}36.26 \\
(14.60)\end{array}$ & $\begin{array}{r}1.42 \\
(0.30)\end{array}$ & $\begin{array}{r}0.46 \\
(0.29)\end{array}$ & $\begin{array}{l}11.56 \\
(0.00)\end{array}$ & $\begin{array}{l}240.24 * \\
(24.04)\end{array}$ \\
\hline $\begin{array}{l}\text { Control - } \\
\text { Wet/Dry }\end{array}$ & $\begin{array}{r}\text { avg } \\
\text { (stdev) }\end{array}$ & $\begin{array}{l}306.92 * \\
(17.32)\end{array}$ & $\begin{array}{r}4.02 \\
(2.07)\end{array}$ & $\begin{array}{r}4.11 \\
(0.99)\end{array}$ & $\begin{array}{r}1.76 \\
(0.44)\end{array}$ & $\begin{array}{r}0.88 \\
(0.24)\end{array}$ & $\begin{array}{c}36.84 \\
(7.15)\end{array}$ & $\begin{array}{r}0.45 \\
(0.19)\end{array}$ & $\begin{array}{r}0.10 \\
(0.05)\end{array}$ & $\begin{array}{r}9.83 \\
(0.34)\end{array}$ & $\begin{array}{r}118.00 \\
(0.07)\end{array}$ \\
\hline
\end{tabular}

* Indicates a significantly greater mean $(\mathrm{P} \leq 0.05)$ between the Flooded and Wet/Dry Cycled Treatments.

Table 7. Comparison of the Pore Water Chemistry for the Flooded and the Wet/Dry Cycled Control Treatments: Constituents-ofConcern

\begin{tabular}{|c|c|c|c|c|c|c|c|c|c|c|c|c|}
\hline & & $\begin{array}{c}\text { As } \\
(\mathrm{ppb})\end{array}$ & $\begin{array}{c}\mathrm{Ba} \\
(\mathrm{ppb})\end{array}$ & $\begin{array}{c}\mathrm{Ce} \\
(\mathrm{ppb})\end{array}$ & $\begin{array}{c}\text { Co } \\
(\mathrm{ppb})\end{array}$ & $\begin{array}{c}\mathrm{Cr} \\
(\mathrm{ppb})\end{array}$ & $\begin{array}{c}\mathrm{K} \\
(\mathrm{ppm})\end{array}$ & $\begin{array}{c}\mathrm{Hg} \\
(\mathrm{ppb})\end{array}$ & $\begin{array}{c}\mathrm{Pb} \\
(\mathrm{ppb})\end{array}$ & $\begin{array}{c}\mathrm{Sr} \\
(\mathrm{ppb})\end{array}$ & $\begin{array}{c}\text { Th } \\
(\mathrm{ppb})\end{array}$ & $\begin{array}{c}\mathrm{U} \\
(\mathrm{ppb})\end{array}$ \\
\hline Control - Flooded & $\begin{array}{r}\text { avg } \\
\text { (stdev) }\end{array}$ & $\begin{array}{l}18.56 * \\
(2.72)\end{array}$ & $\begin{array}{l}462.16 * \\
(37.77)\end{array}$ & $\begin{array}{c}49.43 * \\
(20.81)\end{array}$ & $\begin{array}{l}20.69 \\
(7.14)\end{array}$ & $\begin{array}{r}2.83 \\
(0.75)\end{array}$ & $\begin{array}{r}20.27 \\
(15.93)\end{array}$ & $\mathrm{AI}$ & $\begin{array}{l}7.39 * \\
(0.67)\end{array}$ & $\begin{array}{l}122.05 * \\
(20.23)\end{array}$ & $\begin{array}{r}15.19 \\
(13.51)\end{array}$ & $\begin{array}{r}1.85 \\
(1.19)\end{array}$ \\
\hline Control - Wet/Dry & $\begin{array}{r}\text { avg } \\
\text { (stdev) }\end{array}$ & $\begin{array}{r}0.98 \\
(0.03)\end{array}$ & $\begin{array}{r}106.07 \\
(34.54)\end{array}$ & $\begin{array}{l}17.53 \\
(1.04)\end{array}$ & $\begin{array}{r}8.70 \\
(3.75) \\
\end{array}$ & $\begin{array}{r}2.06 \\
(0.31)\end{array}$ & $\begin{array}{r}6.76 \\
(2.47)\end{array}$ & $\begin{array}{r}3.16 \\
(3.53)\end{array}$ & $\begin{array}{r}1.78 \\
(0.05)\end{array}$ & $\begin{array}{l}32.52 \\
(2.32)\end{array}$ & $\begin{array}{r}0.79 \\
(0.20)\end{array}$ & $\begin{array}{r}0.41 \\
(0.10)\end{array}$ \\
\hline
\end{tabular}

(a) $\mathrm{Ba}$ is used here as an analog for $\mathrm{Ra}$; $\mathrm{Ce}$ for $\mathrm{Ac} ; \mathrm{K}$ for $\mathrm{Tl}$.

(b) $\mathrm{AI}=$ Analytical Interference

* Indicate a significantly greater mean $(\mathrm{P} \leq 0.05)$ between the Flooded and Wet/Dry Cycled Treatments. 


\subsection{PORE WATER CHEMISTRY OF THE FLOODED TREATMENTS}

For the Flooded treatments, the redox status of the $\mathrm{Fe}(0)$, Apatite-NC, and Apatite-NC $+\mathrm{Fe}(0)$ treatments were significantly lower than in the Control (Table 8). The Fe(0) lowered the redox status directly through inorganic reduction and indirectly by promoting microbial growth of iron reducing bacteria. Phosphate from the Apatite-NC may have stimulated microbial growth, which in turn may have lowered the redox status. It is not known why the Apatite II did not have any significant effect on the Eh. In fact, the higher solubility of the Apatite-II would lead one to anticipate that it would produce a greater lowering of the Eh than the apatite-NC.

The increase in $\mathrm{pH}$ associated with both apatites and the $\mathrm{Fe}(0)$ additions can be attributed to the inverse relation that $\mathrm{pH}$ and $\mathrm{Eh}$ have in sediments, and more directly to the proton consuming nature of the dissolution of apatite in water (Equation 2) and the oxidation of $\mathrm{Fe}(0)$ (Equation 4). Furthermore, both apatite minerals likely contain a fair bit of calcium carbonate impurities, which would tend to raise the $\mathrm{pH}$ of the system. The elevated electrical conductivity associated with all treatments is the result of a number of geochemical processes including: the dissolution of the apatite and $\mathrm{Fe}(0)$, the dissolution of $\mathrm{Fe}$-oxides, and release of species sorbed to the dissolved Fe-oxides. The extremely high electrical conductivity of the Apatite II pore water is indicative of the soluble nature and the large number of salts associated with this material.

Table 8. Water Chemistry of the Flooded Treatments: Eh, $\mathrm{O}_{2}, \mathrm{pH}$ and Electrical Conductivity

\begin{tabular}{lrcrcc}
\hline & & $\begin{array}{c}\mathrm{Eh} \\
(\mathrm{mV})\end{array}$ & $\begin{array}{c}\mathrm{O}_{2} \\
(\mathrm{mg} / \mathrm{L})\end{array}$ & $\mathrm{pH}$ & $\begin{array}{c}\text { Electrical } \\
\text { Conductivity } \\
(\mu \mathrm{S} / \mathrm{cm})\end{array}$ \\
\hline Control & $\mathrm{avg}$ & -145.3 & 0.10 & 5.79 & 505.0 \\
& $($ stdev $)$ & $(23.4)$ & $(0.06)$ & $(0.22)$ & $(15.6)$ \\
Apatite-NC & avg & $-175.9 *$ & 0.04 & $6.63 *$ & $605.3 *$ \\
& $($ stdev) & $(3.0)$ & $(0.01)$ & $(0.10)$ & $(19.1)$ \\
Apatite-NC + Fe(0) & avg & $-185.5 *$ & 0.06 & $6.69 *$ & $571.3 *$ \\
& (stdev) & $(2.5)$ & $(0.01)$ & $(0.04)$ & $(17.8)$ \\
$\mathrm{Fe}(0)$ & avg & $-173.3 *$ & 0.11 & $6.29 *$ & $449.3 *$ \\
& $($ stdev) & $(5.5)$ & $(0.11)$ & $(0.03)$ & $(13.6)$ \\
Apatite II & avg & -111.57 & na & $6.65 *$ & $1785.0 *$ \\
& $($ stdev) & $(3.01)$ & na & $(0.07)$ & $(106)$ \\
\hline
\end{tabular}

“*” identifies a treatment mean concentration that is significantly $(\mathrm{P} \leq 0.05)$ different than the control mean concentration, according to Dunett's Test.

na - not available

The sediment amendments produced significant changes to a number of ancillary parameters, as compared to the unamended treatment (Table 10). Most notable of these differences are those associated with the Apatite-II. The concentrations of $\mathrm{Ca}, \mathrm{Na}$, total inorganic $\mathrm{C}$, and total organic 
$\mathrm{C}$ were much greater than in the Control treatment. This is consistent with the extremely large electrical conductivity value for this treatment (Table 8). Phosphorus pore water concentrations in the Apatite-II, but not in the Apatite-NC, treatment were significantly greater than in the Flooded Control. The significant decrease in Al concentrations for all sediment amendments is due to the concomitant increase in $\mathrm{pH}$ (Table 8), which tends to promote Al hydrolysis and precipitation.

Regarding the COC's, the Apatite-NC pore water concentrations of $\mathrm{Ba}$ (an analog for $\mathrm{Ra}$ ), $\mathrm{Ce}$ (an analogue for $\mathrm{Ac}$ ), $\mathrm{Co}, \mathrm{K}$ (an analog for $\mathrm{Tl}$ ), and $\mathrm{Pb}$ were significantly lower than the Flooded Control (Table 11). The $\mathrm{Fe}(0)$ pore water concentrations of $\mathrm{As}, \mathrm{Ba}, \mathrm{Co}, \mathrm{Ce}$, and $\mathrm{Pb}$ were significantly lower than the Flooded Control. The Apatite-NC $+\mathrm{Fe}(0)$ treatment pore water concentrations of $\mathrm{As}, \mathrm{Ba}, \mathrm{Ce}, \mathrm{Co}, \mathrm{K}$, and $\mathrm{Pb}$ were lower than the Control. This list suggests that the benefit of combining both sediment amendments into the same treatment is essentially the sum of the benefits from adding each of the amendments individually. The Apatite-II significantly reduced the pore water concentrations of $\mathrm{Ba}, \mathrm{Ce}$, and $\mathrm{Pb}$.

These sediment amendments also produced some adverse affects on the pore water chemistry. Both apatite treatments caused significant increases in the amount of As and Sr. The As could have been released from the apatite or it may have been desorbed from the sediment as a result of elevated phosphate concentrations caused by the dissolution of the apatite. The elevated $\mathrm{Sr}$ concentration is likely the result of Sr being released from the apatite and Sr being exchanged from the sediment surface sites as a result of elevated concentrations of both $\mathrm{Sr}$ and $\mathrm{Ca}$. It is important to keep in mind that the Sr reported here is stable $\mathrm{Sr}$ and the $\mathrm{Sr}$ of interest is ${ }^{90} \mathrm{Sr}$. The apatite amendments will only contain stable $\mathrm{Sr}$, thus the only potential detrimental affect of adding apatite to a ${ }^{90} \mathrm{Sr}$-contaminated sediment is that it would promote the exchange of adsorbed ${ }^{90} \mathrm{Sr}$ (and would not increase the ${ }^{90} \mathrm{Sr}$ concentration as a result of release from the mineral).

By combining $\mathrm{Fe}(0)$ with Apatite-NC, the increased As concentrations that originated from the Apatite-NC were lowered (Table 11$)$. Fe(0) is known to be very effective at removing As from the aqueous phase (Melitas et al. 2002; Appelo et al. 2002). By including Fe(0) with the Apatite$\mathrm{NC}$, the elevated Sr pore water concentration originating from the Apatite-NC was not lowered.

The Apatite-II pore water contained appreciably more Co and $\mathrm{K}$ than the Flooded Control. The $\mathrm{K}$ is not a problem in itself, but may have the undesirable effect of promoting the exchange of $\mathrm{Tl}^{+}$and $\mathrm{Cs}^{+}$from the sediment surface. The Apatite-NC did not elevate pore water $\mathrm{K}$ concentrations.

Two of the most important risk drivers at the TNX OD site are Th and U. Unfortunately, the pore water concentrations of both COC's were very low, almost at detection limits. These low concentrations were observed in previous studies of TNX OD sediment pore waters and were attributed to their strong sorbing tendency (Kaplan and Serkiz 2000). The low concentrations reduced our ability to detect significant differences between the various treatments and also provided additional data to support the notion that $T h$ and $U$ are indeed strongly associated with the sediment. Apatite is known to be able to remove $U$ from the aqueous phase and maintain its concentration below drinking water limits (Bostick et al. 1999, Conca et al. 2000, Fuller et al. 2002, Rakovan et al. 2002). 


\subsection{PORE WAT ER CHEMISTRY OF THE WET/DRY-CYCLED TREATMENTS}

The influences of the sediment amendments on pore water chemistry of the Wet/Dry-Cycled treatments (Table 9) were not nearly as large as they were in the Flooded treatments (Table 5). However, many significant differences were detected between the amendment treatments and the Wet/Dry-Cycled Control treatment. Surprisingly, the Apatite-NC treatment tended to cause the Eh to decrease more than the $\mathrm{Fe}(0)$. As was the case with the Flooded treatments, all the amendments tended to increase the $\mathrm{pH}$ of the Wet/Dry-Cycled treatments.

Table 9. Ancillary Constituent Pore Water Concentrations in the Wet/Dry Cycled Treatments: $\mathrm{Eh}, \mathrm{O}_{2}, \mathrm{pH}$ and Electrical Conductivity

\begin{tabular}{lrcccc}
\hline & & $\begin{array}{c}\text { Eh } \\
(\mathrm{mV})\end{array}$ & $\begin{array}{c}\mathrm{O}_{2} \\
(\mathrm{mg} / \mathrm{L})\end{array}$ & $\mathrm{pH}$ & $\begin{array}{c}\text { Electrical } \\
\text { Conductivity } \\
(\mu \mathrm{S} / \mathrm{cm})\end{array}$ \\
\hline Control & avg & 286.5 & 5.52 & 4.46 & 263.3 \\
Apatite-NC & avg & $214.4 *$ & $(0.47)$ & $(0.11)$ & $(15.5)$ \\
& $($ stdev & $(11.3)$ & $5.29 *$ & $5.20 *$ & $488.3 *$ \\
Apatite-NC + Fe(0) & avg & $193.4 *$ & $3.32 *$ & $5.67 *$ & $(77.7)$ \\
& (stdev) & $(9.1)$ & $(0.14)$ & $(0.16)$ & 328.3 \\
$\mathrm{Fe}(0)$ & avg & 230.1 & $3.47 *$ & $5.29 *$ & $(7.1)$ \\
& $($ stdev) & $(53.0)$ & $(0.16)$ & $(0.09)$ & 190.7 \\
\hline
\end{tabular}

“*” identifies a treatment mean concentration that is significantly $(\mathrm{P} \leq 0.05)$ different than the control mean concentration, according to Dunett's Test.

The concentrations of the elemental ancillary constituents in the Wet/Dry-Cycled treatments (Table 12) followed similar, but less dramatic, trends as in the Flooded treatments (Table 6). The constituent levels in the $\mathrm{Fe}(0)$ pore water differed very little from those in the control. In contrast, most of the ancillary parameters in the Apatite-NC pore water differed with those in the Control. 
Table 10. Pore Water Chemical Concentrations of Ancillary Parameters in the Flooded Treatments

\begin{tabular}{|c|c|c|c|c|c|c|c|c|c|c|c|}
\hline & & $\begin{array}{c}\mathrm{Al} \\
(\mathrm{ppb})\end{array}$ & $\begin{array}{c}\mathrm{Ca} \\
(\mathrm{ppm})\end{array}$ & $\begin{array}{c}\mathrm{Fe} \\
(\mathrm{ppm})\end{array}$ & $\begin{array}{c}\mathrm{Mg} \\
(\mathrm{ppm})\end{array}$ & $\begin{array}{c}\mathrm{Mn} \\
(\mathrm{ppm})\end{array}$ & $\begin{array}{c}\mathrm{Na} \\
(\mathrm{ppm})\end{array}$ & $\begin{array}{c}\mathrm{P} \\
(\mathrm{ppm})\end{array}$ & $\begin{array}{c}\mathrm{Se} \\
(\mathrm{ppm})\end{array}$ & $\begin{array}{c}\text { TIC } \\
(\mathrm{ppm})\end{array}$ & $\begin{array}{l}\text { TOC } \\
(\mathrm{ppm})\end{array}$ \\
\hline \multirow[t]{2}{*}{ Control } & avg & 233.83 & 12.44 & 177.10 & 7.39 & 5.42 & 36.26 & 1.42 & 0.46 & 11.56 & 240.24 \\
\hline & (stdev) & $(26.20)$ & $(1.35)$ & $(35.98)$ & $(1.01)$ & $(1.14)$ & $(14.60)$ & $(0.30)$ & $(0.29)$ & $(0.00)$ & $(24.04)$ \\
\hline \multirow[t]{2}{*}{ Apatite-NC } & avg & $67.58 *$ & $75.51 *$ & 118.00 & $10.55 *$ & $3.66 *$ & 28.41 & 1.23 & $0.72 *$ & 12.77 & $166.0 *$ \\
\hline & (stdev) & $(6.54)$ & $(4.00)$ & $(7.89)$ & $(0.57)$ & $(0.21)$ & $(1.78)$ & $(0.04)$ & $(0.01)$ & $(1.17)$ & (19.4) \\
\hline \multirow[t]{4}{*}{ Apatite- $\mathrm{NC}+\mathrm{Fe}(0)$} & avg & $55.16 *$ & $63.72 *$ & 125.23 & $11.21 *$ & 4.72 & 27.04 & 1.22 & 0.69 & 10.78 & 245.7 \\
\hline & (stdev) & $(5.06)$ & $(5.76)$ & (11.61) & $(0.35)$ & $(0.24)$ & $(0.57)$ & $(0.17)$ & $(0.07)$ & $(0.08)$ & (3.9) \\
\hline & avg & $46.29 *$ & 15.08 & 171.77 & 8.81 & 6.51 & 24.60 & 1.34 & 0.51 & 10.41 & $253.6 *$ \\
\hline & (stdev) & $(7.58)$ & $(0.38)$ & $(9.52)$ & $(0.22)$ & $(0.57)$ & $(1.34)$ & $(0.01)$ & $(0.06)$ & $(0.13)$ & $(5.4)$ \\
\hline Apatite-II & $\begin{array}{r}\text { Avg } \\
\text { (stdev) }\end{array}$ & $\begin{array}{l}29.52 * \\
(4.16)\end{array}$ & $\begin{array}{c}321.77 * \\
(8.55)\end{array}$ & $\begin{array}{c}214.47 * \\
(4.5)\end{array}$ & AI & $\begin{array}{c}2.26 \\
(0.08)\end{array}$ & $\begin{array}{l}210.10 * \\
(60.27)\end{array}$ & $\begin{array}{c}3.38 * \\
(0.03)\end{array}$ & $\begin{array}{r}1.75 \\
(0.03)\end{array}$ & $\begin{array}{l}26.38 * \\
(2.48)\end{array}$ & $\begin{array}{c}1653 * \\
(89)\end{array}$ \\
\hline
\end{tabular}

* identifies a treatment mean concentration that is significantly $(\mathrm{P} \leq 0.05)$ different than the control mean concentration, according to Dunett's Test.

Table 11. Constituent-of-Concern Concentrations in the Pore Water of the Flooded Treatments

\begin{tabular}{|c|c|c|c|c|c|c|c|c|c|c|c|c|}
\hline & & $\begin{array}{c}\text { As } \\
\text { (ppm }\end{array}$ & $\begin{array}{l}\mathrm{Ba}^{(\mathrm{a})} \\
(\mathrm{ppb})\end{array}$ & $\begin{array}{l}\mathrm{Ce}^{(\mathrm{a})} \\
(\mathrm{ppb})\end{array}$ & $\begin{array}{c}\mathrm{Co} \\
(\mathrm{ppb})\end{array}$ & $\begin{array}{c}\mathrm{Cr} \\
(\mathrm{ppb})\end{array}$ & $\begin{array}{c}\mathrm{K}^{(\mathrm{a})} \\
(\mathrm{ppm})\end{array}$ & $\begin{array}{c}\mathrm{Hg} \\
(\mathrm{ppb})\end{array}$ & $\begin{array}{c}\mathrm{Pb} \\
(\mathrm{ppb})\end{array}$ & $\begin{array}{c}\mathrm{Sr} \\
(\mathrm{ppb})\end{array}$ & $\begin{array}{c}\text { Th } \\
\text { (ppb) }\end{array}$ & $\begin{array}{c}\mathrm{U} \\
(\mathrm{ppb})\end{array}$ \\
\hline Control & $\begin{array}{r}\text { avg } \\
(\text { stdev) }\end{array}$ & $\begin{array}{l}18.56 \\
(2.72)\end{array}$ & $\begin{array}{l}462.16 \\
(37.77)\end{array}$ & $\begin{array}{r}49.43 \\
(20.81)\end{array}$ & $\begin{array}{l}20.69 \\
(7.14)\end{array}$ & $\begin{array}{r}2.83 \\
(0.75)\end{array}$ & $\begin{array}{r}20.27 \\
(15.93)\end{array}$ & AI & $\begin{array}{r}7.39 \\
(0.67)\end{array}$ & $\begin{array}{r}122.05 \\
(20.23)\end{array}$ & $\begin{array}{r}15.19 \\
(13.51)\end{array}$ & $\begin{array}{r}1.85 \\
(1.19)\end{array}$ \\
\hline Apatite-NC & $\begin{array}{r}\text { avg } \\
(\text { stdev })\end{array}$ & $\begin{array}{l}23.00 * \\
(1.30)\end{array}$ & $\begin{array}{l}288.36 * \\
(17.83)\end{array}$ & $\begin{array}{c}9.60 * \\
(3.12)\end{array}$ & $\begin{array}{l}9.53 * \\
(3.14)\end{array}$ & $\begin{array}{r}2.45 \\
(0.79)\end{array}$ & $\begin{array}{c}7.45 * \\
(0.24)\end{array}$ & AI & $\begin{array}{c}1.47 * \\
(0.96)\end{array}$ & $\begin{array}{c}336.4 * \\
(39.65)\end{array}$ & $\begin{array}{r}3.03 \\
(0.74)\end{array}$ & $\begin{array}{r}5.84 \\
(2.80)\end{array}$ \\
\hline Apatite- $\mathrm{NC}+\mathrm{Fe}(0)$ & $\begin{array}{r}\text { avg } \\
(\text { stdev })\end{array}$ & $\begin{array}{c}7.91 * \\
(0.52)\end{array}$ & $\begin{array}{l}285.33 * \\
(13.08)\end{array}$ & $\begin{array}{r}5.43 * \\
(1.36)\end{array}$ & $\begin{array}{c}6.96 * \\
(1.73)\end{array}$ & $\begin{array}{r}1.93 \\
(0.48)\end{array}$ & $\begin{array}{r}7.51 * \\
(0.08)\end{array}$ & AI & $\begin{array}{c}0.67 * \\
(0.13)\end{array}$ & $\begin{array}{l}325.9 * \\
(1.08)\end{array}$ & $\begin{array}{r}2.11 \\
(0.57)\end{array}$ & $\begin{array}{r}3.74 \\
(1.27)\end{array}$ \\
\hline $\mathrm{Fe}(0)$ & $\begin{array}{r}\text { avg } \\
(\text { stdev })\end{array}$ & $\begin{array}{l}5.91 * \\
(0.58)\end{array}$ & $\begin{array}{l}417.32 \\
(17.35)\end{array}$ & $\begin{array}{l}10.22 * \\
(1.55)\end{array}$ & $\begin{array}{c}6.22 * \\
(0.68)\end{array}$ & $\begin{array}{r}1.82 \\
(0.37)\end{array}$ & $\begin{array}{r}8.28 * \\
(0.25)\end{array}$ & AI & $\begin{array}{l}0.76 * \\
(0.11)\end{array}$ & $\begin{array}{l}126.3 \\
(4.20)\end{array}$ & $\begin{array}{r}1.06 \\
(0.04)\end{array}$ & $\begin{array}{r}1.07 \\
(0.13)\end{array}$ \\
\hline Apatite-II & $\begin{array}{r}\text { avg } \\
(\text { stdev })\end{array}$ & $\begin{array}{l}47.34 * \\
(6.13)\end{array}$ & $\begin{array}{l}186.06 * \\
(18.09)\end{array}$ & $\begin{array}{c}1.28 * \\
(0.43)\end{array}$ & $\begin{array}{l}39.71 * \\
(5.21)\end{array}$ & $\begin{array}{r}2.32 \\
(0.35)\end{array}$ & $\begin{array}{r}67.97 \\
(30.17)\end{array}$ & $\begin{array}{r}3.33 \\
(2.57)\end{array}$ & $\begin{array}{c}0.89 * \\
(0.20)\end{array}$ & $\begin{array}{r}109.14 \\
(6.12)\end{array}$ & $\begin{array}{r}16.36 \\
(19.32)\end{array}$ & $\begin{array}{r}0.88 \\
(0.62)\end{array}$ \\
\hline
\end{tabular}

(a) $\mathrm{Ba}$ is used here as an analog for $\mathrm{Ra}$; Ce for $\mathrm{Ac} ; \mathrm{K}$ for $\mathrm{Tl}$.

(b) $\mathrm{AI}=$ Analytical interference, data not available.

* identifies a treatment mean concentration that is significantly $(\mathrm{P} \leq 0.05)$ different than the control mean concentration, according to Dunett's Test. 
Perhaps one of the most important points to make regarding Table 12 is that the Apatite-NC pore water had a significantly higher total organic $\mathrm{C}$ concentration than the Wet/Dry-Cycled Control. The high organic $\mathrm{C}$ concentrations in the leachate were apparent to the naked eye, insofar that the water from this treatment had a brown tinge. The elevated organic $\mathrm{C}$ concentrations was likely caused by the increased $\mathrm{pH}$, which would have caused the organic matter to become more negatively charged, and therefore more repulsed from the primarily negatively charged sediment surfaces. Additionally or alternatively, the increased phosphate and $\mathrm{Ca}$ concentrations may have promoted the desorption of organic matter from sediment surfaces via anion and cation exchange, respectively. The enhanced total organic $\mathrm{C}$ concentration is important for evaluating these sediment amendments because organic matter is a strong complexing agent of many of the COC's and may enhance their mobilization.

The sediment amendments were generally less effective in the Wet/Dry-Cycled treatments (Table 13) than they were in the Flooded treatments (Table 11) at immobilizing COC's. This may be attributed in part to less chemistry taking place in the partially moistened samples. The shorter contact time between the surface water and the treated sediments in the partially moistened systems may have limited the extent that several important sequestration reactions occurred. These reactions may have included COC desorption followed by re-adsorption, apatite dissolution, $\mathrm{Fe}(0)$ reduction, and microbial reduction. $\mathrm{Fe}(0)$ and Apatite-NC were very effective at removing $\mathrm{Pb}$. The adverse influence of the Apatite- $\mathrm{NC}$ on As and $\mathrm{Sr}$ concentrations observed in the Flooded treatments were also observed in the Wet/Dry-Cycled treatments. 
Table 12. Pore Water Chemical Concentrations of Ancillary Parameters in the Wet/Dry Cycling Treatments

\begin{tabular}{|c|c|c|c|c|c|c|c|c|c|c|c|}
\hline & & $\begin{array}{c}\mathrm{Al} \\
(\mathrm{ppb})\end{array}$ & $\begin{array}{c}\mathrm{Ca} \\
(\mathrm{ppm})\end{array}$ & $\begin{array}{c}\mathrm{Fe} \\
(\mathrm{ppm})\end{array}$ & $\begin{array}{c}\mathrm{Mg} \\
(\mathrm{ppm})\end{array}$ & $\begin{array}{c}\mathrm{Mn} \\
(\mathrm{ppm})\end{array}$ & $\begin{array}{c}\mathrm{Na} \\
(\mathrm{ppm})\end{array}$ & $\begin{array}{c}\mathrm{P} \\
(\mathrm{ppm})\end{array}$ & $\begin{array}{c}\mathrm{Se} \\
(\mathrm{ppm})\end{array}$ & $\begin{array}{c}\text { TIC } \\
(\mathrm{ppm})\end{array}$ & $\begin{array}{l}\text { TOC } \\
\text { (ppm) }\end{array}$ \\
\hline \multirow[t]{2}{*}{ Control } & avg & 306.92 & 4.02 & 4.11 & 1.76 & 0.88 & 36.84 & 0.45 & 0.10 & 9.83 & 118.00 \\
\hline & (stdev) & $(17.32)$ & $(2.07)$ & $(0.99)$ & $(0.44)$ & $(0.24)$ & $(7.15)$ & $(0.19)$ & $(0.05)$ & $(0.34)$ & $(0.07)$ \\
\hline \multirow[t]{2}{*}{ Apatite-NC } & avg & 474.68 & $39.35 *$ & $1.20 *$ & $4.58 *$ & 0.40 & 47.33 & $1.00 *$ & $0.30 *$ & 10.19 & $228.3 *$ \\
\hline & (stdev) & $(67.68)$ & $(9.27)$ & $(0.55)$ & $(1.10)$ & $(0.26)$ & $(8.07)$ & $(0.13)$ & $(0.06)$ & $(0.29)$ & (31.4) \\
\hline \multirow[t]{2}{*}{ Apatite- $\mathrm{NC}+\mathrm{Fe}(0)$} & avg & 866.12 * & 15.90 & $1.34 *$ & 2.39 & 0.21 & 36.97 & 0.64 & 0.14 & 10.19 & 143.6 \\
\hline & (stdev) & $(55.11)$ & $(0.74)$ & $(0.42)$ & $(0.07)$ & $(0.07)$ & $(2.14)$ & $(0.06)$ & $(0.03)$ & $(0.02)$ & $(6.6)$ \\
\hline \multirow[t]{2}{*}{$\mathrm{Fe}(0)$} & avg & 302.56 & 2.27 & $1.26 *$ & 0.74 & 0.38 & 27.15 & 0.45 & 0.05 & 10.51 & 115.3 \\
\hline & (stdev) & $(31.44)$ & $(1.17)$ & $(0.42)$ & $(0.33)$ & $(0.18)$ & $(2.47)$ & $(0.09)$ & $(0.02)$ & $(0.00)$ & $(3.6)$ \\
\hline
\end{tabular}

* identifies a treatment mean concentration that is significantly $(\mathrm{P} \leq 0.05)$ different than the control mean concentration, according to Dunett's Test.

Table 13. Constituent-of-Concern Concentrations in the Pore Water of the Wet/Dry Cycled Treatments

\begin{tabular}{|c|c|c|c|c|c|c|c|c|c|c|c|c|}
\hline & & $\begin{array}{r}\mathrm{As} \\
(\mathrm{ppb})\end{array}$ & $\begin{array}{l}\mathrm{Ba}^{(\mathrm{a})} \\
(\mathrm{ppb})\end{array}$ & $\begin{array}{l}\mathrm{Ce}^{(\mathrm{a})} \\
(\mathrm{ppb})\end{array}$ & $\begin{array}{c}\mathrm{Co} \\
(\mathrm{ppb})\end{array}$ & $\begin{array}{c}\mathrm{Cr} \\
(\mathrm{ppb})\end{array}$ & $\begin{array}{c}\mathrm{K}^{(\mathrm{a})} \\
(\mathrm{ppm})\end{array}$ & $\begin{array}{c}\mathrm{Hg} \\
(\mathrm{ppb})\end{array}$ & $\begin{array}{c}\mathrm{Pb} \\
(\mathrm{ppb})\end{array}$ & $\begin{array}{c}\mathrm{Sr} \\
(\mathrm{ppb})\end{array}$ & $\begin{array}{c}\mathrm{Th} \\
(\mathrm{ppb})\end{array}$ & $\begin{array}{c}\mathrm{U} \\
(\mathrm{ppb})\end{array}$ \\
\hline \multirow[t]{2}{*}{ Control } & Avg & 0.98 & 106.07 & 17.53 & 8.70 & 2.06 & 6.76 & 3.16 & 1.78 & 32.52 & 0.79 & 0.41 \\
\hline & (stdev) & $(0.03)$ & $(34.54)$ & $(1.04)$ & $(3.75)$ & $(0.31)$ & $(2.47)$ & $(3.53)$ & $(0.05)$ & $(2.32)$ & $(0.20)$ & $(0.10)$ \\
\hline \multirow[t]{2}{*}{ Apatite-NC } & avg & $2.35 *$ & 104.28 & 13.88 & 4.19 & $3.75 *$ & 7.15 & 2.97 & $0.86 *$ & $249.22 *$ & 1.21 & 0.32 \\
\hline & (stdev) & $(0.39)$ & $(29.70)$ & $(4.20)$ & $(1.73)$ & $(0.51)$ & $(0.98)$ & $(0.48)$ & $(0.15)$ & (76.77) & $(0.35)$ & $(0.06)$ \\
\hline \multirow[t]{2}{*}{ Apatite-NC $+\mathrm{Fe}(0)$} & avg & 1.18 & 45.95 & 2.94 & 0.97 & 1.46 & 5.38 & 2.15 & $0.87 *$ & 90.56 & 0.72 & $0.20 *$ \\
\hline & (stdev) & $(0.22)$ & $(3.77)$ & $(0.45)$ & $(0.25)$ & $(0.47)$ & $(0.18)$ & $(1.43)$ & $(0.29)$ & $(5.45)$ & $(0.02)$ & $(0.05)$ \\
\hline $\mathrm{Fe}(0)$ & (stdev) & $(0.15)$ & $(20.24)$ & (1.99) & $(1.79)$ & $(0.33)$ & $(0.89)$ & $(0.23)$ & $(0.19)$ & (3.08) & $(0.09)$ & $(0.06)$ \\
\hline
\end{tabular}

(a) $\mathrm{Ba}$ is used here as an analog for Ra; Ce for Ac; $\mathrm{K}$ for $\mathrm{Tl}$.

* identifies a treatment mean concentration that is significantly $(\mathrm{P} \leq 0.05)$ different than the control mean concentration, according to Dunett's Test. 


\subsection{SEQUENTI AL EXTRACTIONS AND "POTENTIALLY LEACHABLE SOURCE- TERM FRACTION"}

Sequential extractions were conducted on the sediments from the Flooded treatments (except for the Apatite-II treatment, Figure 3 through Figure 6, the means and standard deviations associated with these data are presented in Appendix Table 4 through Appendix Table 7).

There are two important factors that come into play when interpreting sequential extraction data. The first is that the various fractions are operationally defined, and that the targeted fraction may or may not be entirely recovered by a given extraction procedure. The other important consideration is that in order to observe a positive response (COC immobilization) to the sediment amendment through measurements of the solid phase, the COC must first desorb from the sediment and re-sorb onto or into the sediment amendment. These are generally kinetically hindered reactions and often take several months to reach steady state. Although such durations are long with respect to this study, they are not long with respect to their application at the TNX OD site. The net effect of collecting data prior to achieving steady state is that less transition of the COC into the immobilized fractions will be measured. Additional discussions about interpreting the results of this short-term study in relation to the long-term reaction rates are presented in Section 4.6. Given these two important caveats, namely the operational definition of the fractions and the incomplete desorption and re-sorption into the sediment amendments, it is possible to discuss the data in a less rigorous manner, being cautious not to over interpret the data.

The main intent of conducting sequential extractions is to determine how strongly the COC's are bound to the solid phase. Early extraction steps (the exchangeable, amorphous Fe-oxide and the organic/sulfide fractions) tend to recover COC fractions that are less strongly bound than the fractions collected in the latter extraction steps (crystalline Fe-oxide and residue fractions). Thus, an indication that a given sediment amendment is sequestering a $\mathrm{COC}$ in a desirable manner would be an increase in the crystalline Fe-oxide and residue fractions when compared to the untreated Control sediment (Table 14 and Table 15). Such a shift was observed with:

- As for the Apatite- $\mathrm{NC}+\mathrm{Fe}(0)$ treatment and the $\mathrm{Fe}(0)$ treatment,

- $\mathrm{Ba}$ for the $\mathrm{Fe}(0)$ treatment,

- Co for the Apatite- $\mathrm{NC}+\mathrm{Fe}(0)$ treatment and the $\mathrm{Fe}(0)$ treatment,

- $\mathrm{Hg}$ for the Apatite- $\mathrm{NC}+\mathrm{Fe}(0)$ treatment and the $\mathrm{Fe}(0)$ treatment, and

- Th for the Apatite- $\mathrm{NC}+\mathrm{Fe}(0)$ treatment and the $\mathrm{Fe}(0)$ treatment.

The sequential extractions also revealed some undesirable shifts in the COC concentrations as a result of adding sediment amendments. They include a decrease in the sum of the Crystalline Fe-oxide and Residual Fractions for the following:

- Co for the Apatite-NC treatment,

- $\mathrm{Pb}$ for the Apatite- $\mathrm{NC}+\mathrm{Fe}(0)$ treatment and the $\mathrm{Fe}(0)$ treatment,

- $\mathrm{Sr}$ for the Apatite-NC treatment,

- Th for the Apatite-NC treatment, and 
- $\mathrm{U}$ for the Apatite-NC $+\mathrm{Fe}(0)$ treatment and the Apatite-NC treatment.

The COC's that existed in appreciably higher concentrations in the Apatite-NC than in an uncontaminated sediment collected from near the TNX OD site were $\mathrm{As}, \mathrm{Cr}, \mathrm{Hg}, \mathrm{Pb}$, and $\mathrm{U}$ (Table 4). These high concentrations may confirm the ability of the apatite to concentrate the COC's from water with low COC levels during geological time frames. Alternatively, if these elements were present at the time the apatite was formed, then these data indicate that the apatite has been able to retain them for very long periods of time. The high As concentrations are not surprising because arsenate $\left(\mathrm{AsO}_{4}{ }^{3-}\right)$ and phosphate $\left(\mathrm{PO}_{4}{ }^{3-}\right)$ have similar geochemical behavior. The high concentrations of $\mathrm{Cr}, \mathrm{Hg}, \mathrm{Pb}$ and $\mathrm{U}$ are indicative of the high retention potential of apatite for these elements.

Sequential extractions were also conducted on the Apatite-NC amendment (Table 16). For purposes of comparison, the same sequential extraction procedure used with the sediments was used for the apatite. Although this eases comparison, the sequence of extractions is not optimal for phosphate phases, such as apatite. Instead, a sequential extraction designed specifically for phosphate would be more meaningful in terms of chemistry (e.g., Kuo 1996). For example, the Organic/Sulfide Fraction accounted for as much as $33 \%$ of the COC, yet neither organic nor sulfide exist to any appreciable extent in the Apatite-NC. Thus, the hydrogen peroxide used in this step removes some fraction that is likely not comprised of organics or sulfides. Instead it dissolves some other phases that are oxidizable by $\mathrm{H}_{2} \mathrm{O}_{2}$. (For this reason, many scientists prefer to refer to the sequential extraction steps by their extractants, rather than their targeted fraction.)

Between $86 \%$ and $92 \%$ of $\mathrm{As}, \mathrm{Cr}, \mathrm{Hg}, \mathrm{Pb}$, or U (the COC's that existed in high concentrations in the Apatite-NC; Table 4) was associated with the two least labile (most mobile) fractions (Table 16). ${ }^{2}$ Of these COC's, the sequential extraction results for the Hg elicit the most concern. Given the extremely low permissible environmental limits imposed by regulators, introducing into the TNX OD $0.69 \mathrm{mg} / \mathrm{kg}$ of $\mathrm{Hg}$ (13\% of $5.32 \mathrm{mg} / \mathrm{kg} \mathrm{Hg}$; Table 16) with the Apatite-NC requires close scrutiny. Another potential problem may exist with the amounts and proportions of mobile As in the Apatite-NC amendment. The leach test indicated that the As concentrations in the Apatite-NC treatments were significantly greater than in the Control in the Flooded treatment (Table 11) and in the Wet/Dry-Cycled treatment (Table 13). Leachate Cr in the Wet/DryCycled, but not in the Flooded, treatments was also significantly higher in the Apatite-NC amended sediment than in the Control.

\footnotetext{
${ }^{2}$ In discussing the sequential extractions of the quarried apatite, Apatite-NC, the mobile phase will be defined as that associated with the first two extraction steps (1- $\mathrm{M} \mathrm{CH}_{3} \mathrm{COONa}, \mathrm{pH}=5$; and $\left.0.25 \mathrm{M} \mathrm{NH}_{2} \mathrm{OH}-\mathrm{HCl}\right)$, the hydrogen peroxide oxidation fraction, referred to as the Organic/Sulfide Fraction, will be considered as part of the immobile fraction. This exception is used because there is essentially no organic matter in this the apatite and the only reason that the Organic/Sulfide fraction was included in the "mobile fraction" was because of the relatively rapid rate at which organic matter, compared to likely inorganic soil phases, oxidizes. Since there is no organic matter in the Apatite-NC, this conservative assumption, which errors on the side of assuming more COC is associated with the mobile phase, is not warranted.
} 
Another way of viewing this same data is through the concept of the potential leachable sourceterm fraction, as defined by:

$$
\% \text { Potential Leachable Source-Term }=100-(\text { Strongly Sorbing Fraction })
$$

where the Strongly Sorbing fraction is the sum of the Crystalline Fe-oxide fraction (Fraction \#3 and the Residual fraction (Fraction \#5). This construct provides a conservative estimate of the percentage of a COC in the source term (contaminated sediment) that has the potential to leach. This is conservative because, as mentioned above, had the experiment been conducted over a longer period, more of the COC's would have had time to desorb from the sediment and resorb onto or into the amendments. For example, Table 14 shows that $80.5 \%$ of the As in the sediment was associated with the strongly sorbing fraction of the Apatite- $\mathrm{NC}+\mathrm{Fe}(0)$ treatment. Using Equation 5, the percent of As that may potential leach from the sediment is $19.5 \%$, or $1.79 \mathrm{mg} / \mathrm{kg}$ As (19.5\% of $9.2 \mathrm{mg} / \mathrm{kg}$ As Table 4). By not adding any amendment to the sediment, $22.7 \%$ of the As in the sediment is leachable. By adding Apatite- $\mathrm{NC}+\mathrm{Fe}(0)$, this fraction significantly decreases to 19.5\%. Perhaps the most striking data in Table 14 deals with Cr. In the Control, only $19.3 \%$ of the total $\mathrm{Cr}$ pool is leachable. Although the addition of Apatite- $\mathrm{NC}+\mathrm{Fe}(0) \mathrm{did}$ not further reduce the leachable fraction, it does indicate that the $\mathrm{Cr}$ on the site is likely not the mobile $\mathrm{Cr}(\mathrm{VI})$ species, but more likely the immobile $\mathrm{Cr}$ (III) species. No benefit was realized for immobilizing the $\mathrm{Cr}$ through the addition of $\mathrm{Fe}(0)$ because all the $\mathrm{Cr}$ was presumably already in the reduced form. 
As

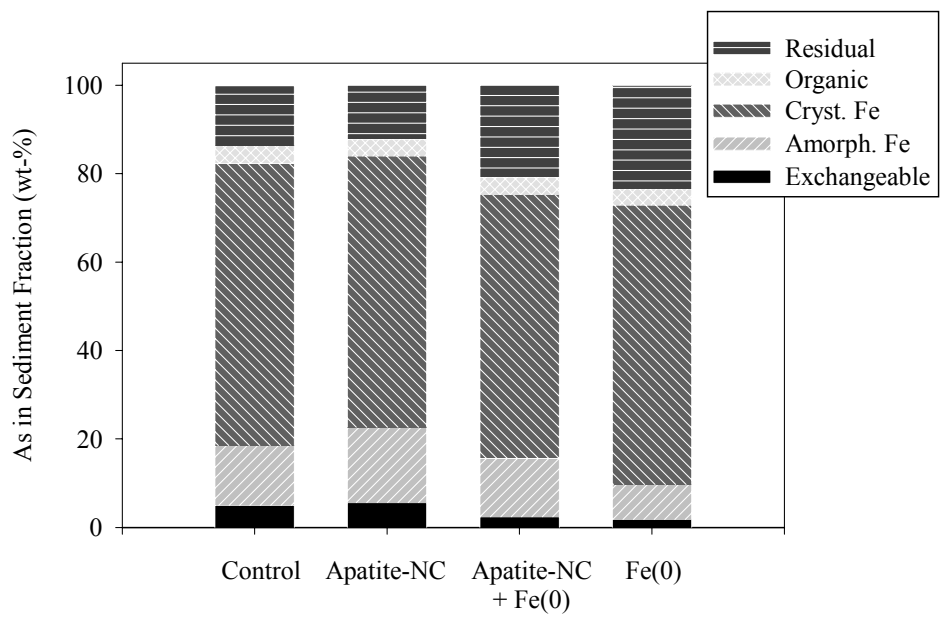

Ba (as an Analog for Ra)
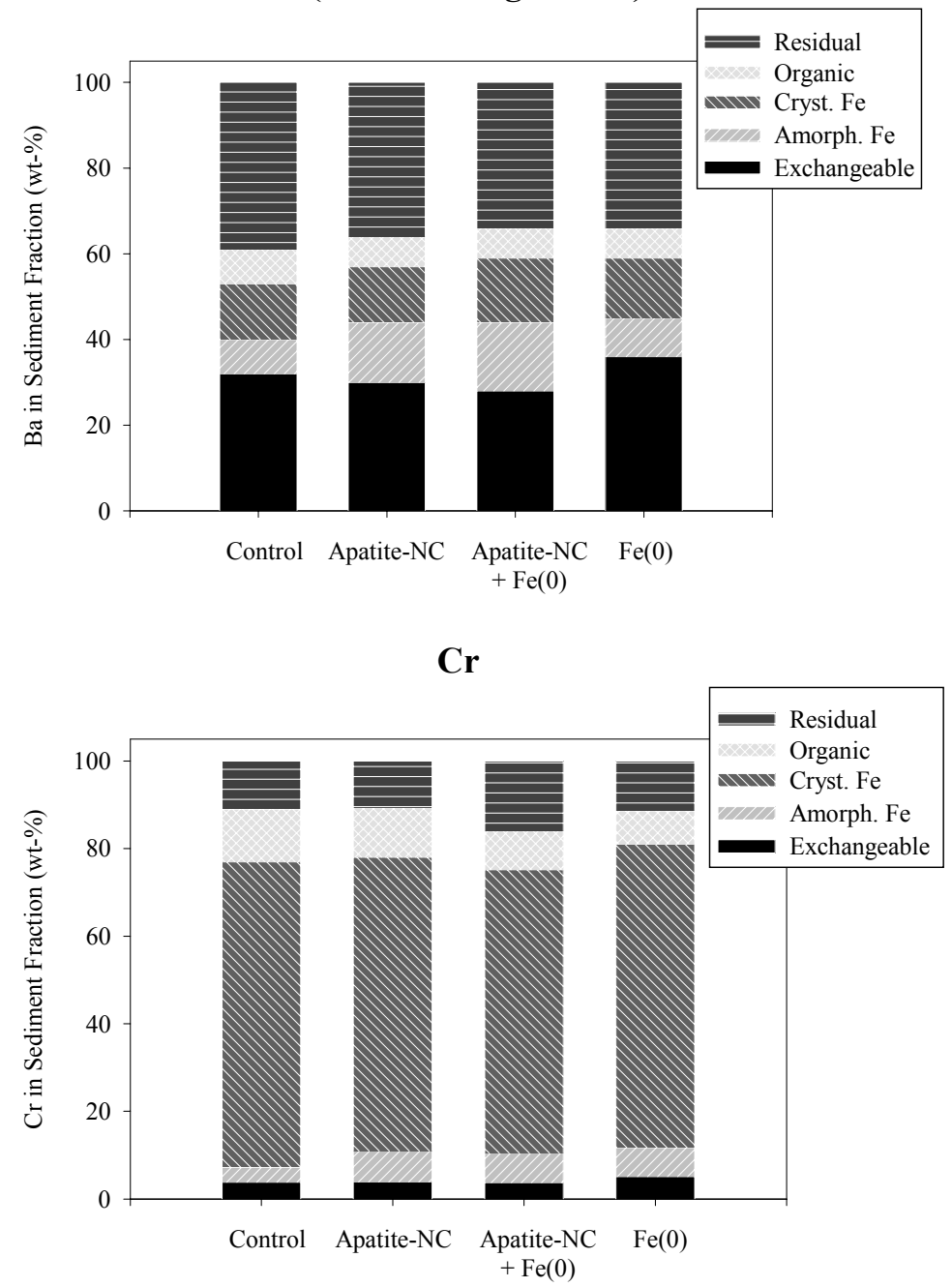

Figure 3. Sequential Extraction of Sediment As, Ba, and Cr After 7-weeks of Contact Time 

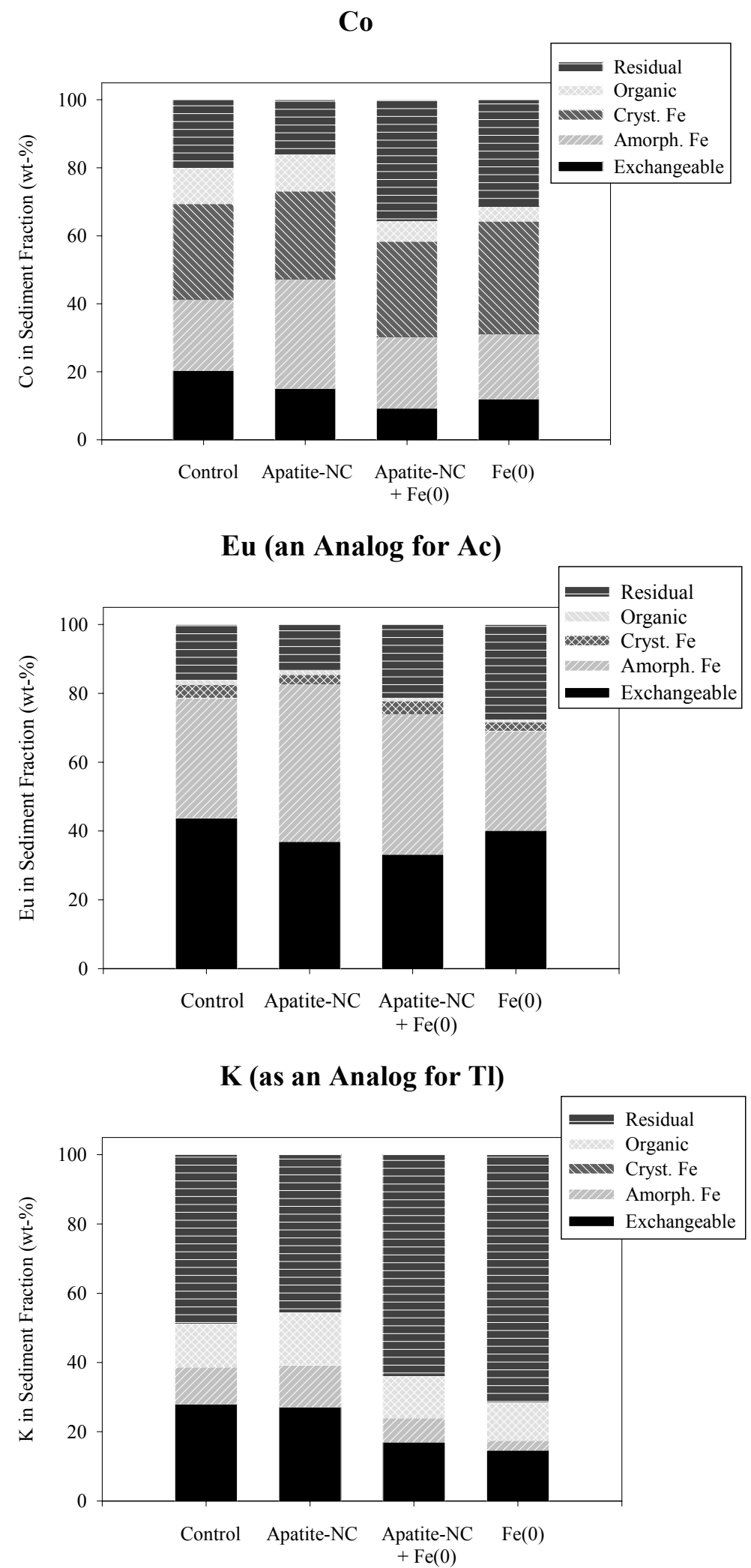

Figure 4. Sequential Extraction of Sediment Co, Eu, and K After 7-weeks of Contact Time 


\section{$\mathbf{P b}$}

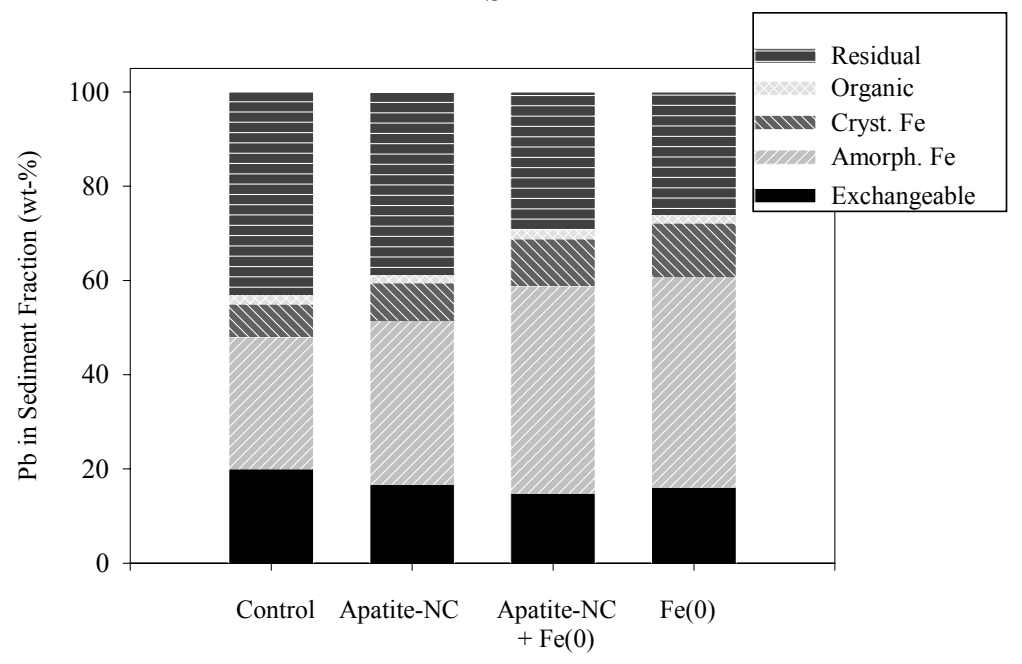

Se
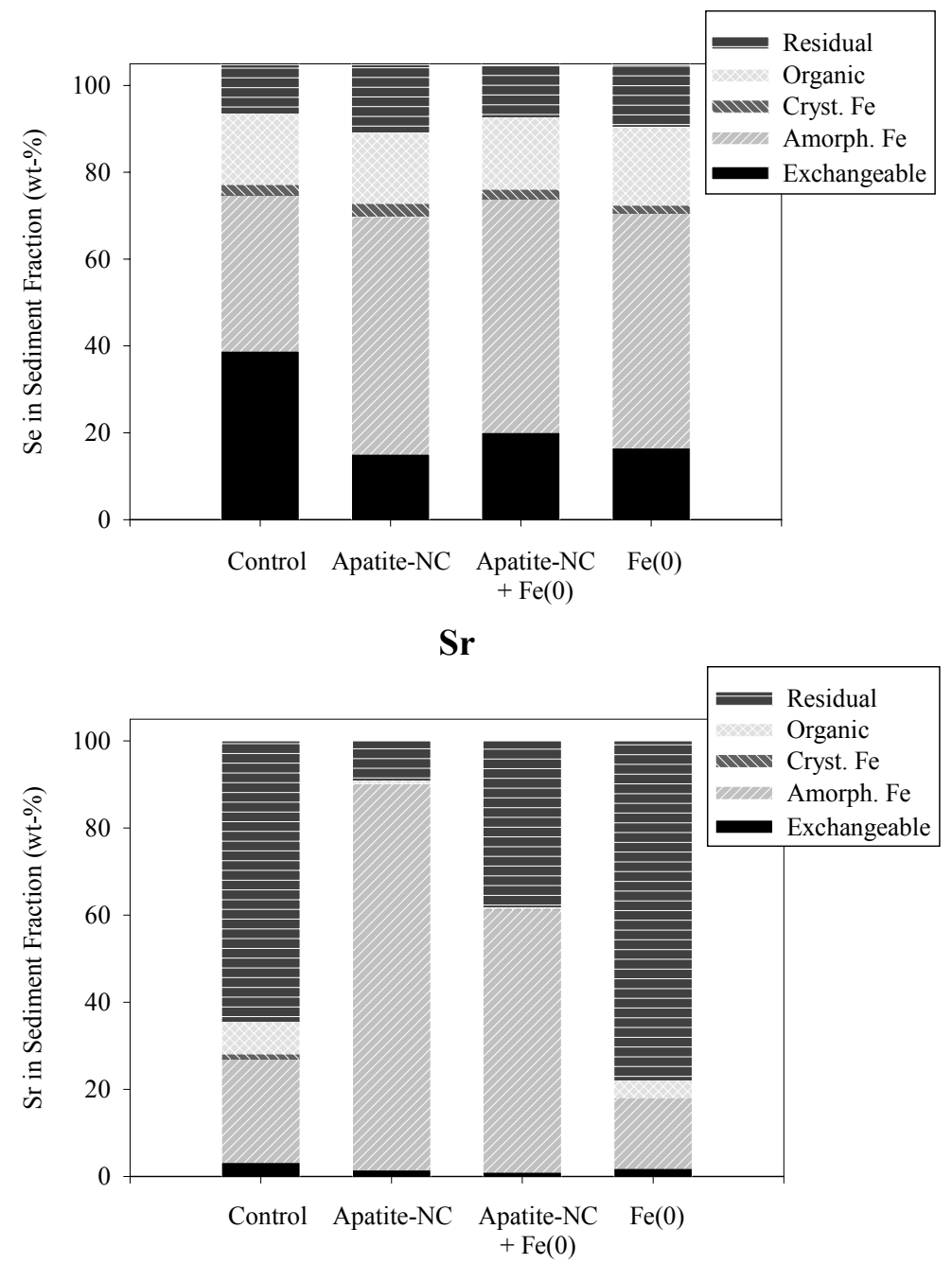

Figure 5. Sequential Extraction of Sediment $\mathrm{Pb}, \mathrm{Se}$, and $\mathrm{Sr}$ After 7-weeks of Contact Time 


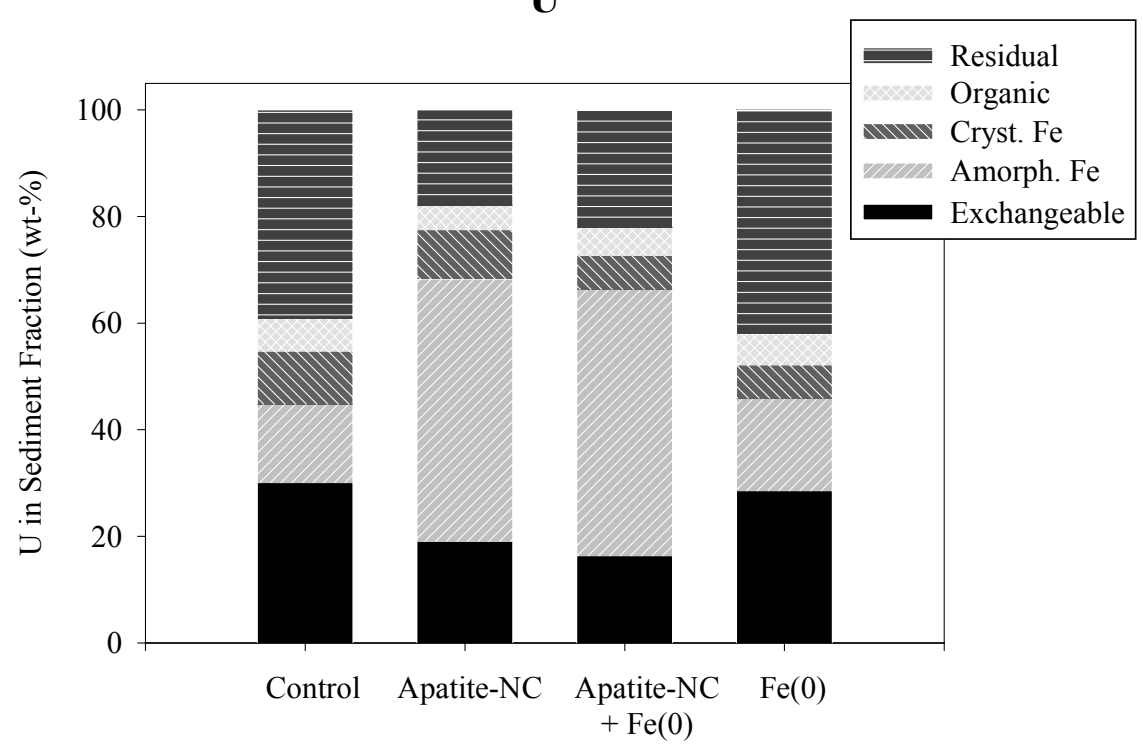

Figure 6. Sequential Extraction of Sediment Th and U After 7-weeks of Contact Time 
Table 14. Percentage of Constituent-of-Concern Associated with Strongly Sorbing Fraction $(100-$ Strongly Sorbing Fraction $=\%$ of Source Term That is Potentially Leachable; Equation 5)

\begin{tabular}{lrlllllllllccc}
\hline & & $\mathrm{As}$ & $\mathrm{Ba}$ & $\mathrm{Eu}$ & $\mathrm{Co}$ & $\mathrm{Cr}$ & $\mathrm{Hg}$ & $\mathrm{K}$ & $\mathrm{Pb}$ & $\mathrm{Sr}$ & $\mathrm{Th}$ & $\mathrm{U}$ \\
\hline Control $^{\text {(a) }}$ & $\mathrm{avg}$ & 77.3 & 51.9 & 20.0 & 48.1 & 80.7 & 56.1 & 48.5 & 50.5 & 65.5 & 41.6 & 49.2 \\
& (stdev) & $(1.0)$ & $(0.3)$ & $(2.7)$ & $(1.8)$ & $(1.0)$ & $(5.0)$ & $(2.7)$ & $(0.7)$ & $(5.5)$ & $(5.0)$ & $(1.8)$ \\
Apatite-NC & $\mathrm{avg}$ & $73.5 *$ & 49.6 & 16.2 & $41.7 *$ & 77.7 & 61.5 & 46.0 & 46.7 & $9.0 *$ & $31.3 *$ & $27.2 *$ \\
& (stdev) & $(0.3)$ & $(0.9)$ & $(3.1)$ & $(0.8)$ & $(0.9)$ & $(2.7)$ & $(7.7)$ & $(0.2)$ & $(1.9)$ & $(1.9)$ & $(1.4)$ \\
Apatite-NC + Fe(0) & $\mathrm{avg}$ & $80.5 *$ & 49.0 & 25.0 & $63.5 *$ & 80.7 & $72.1 *$ & 81.5 & $39.1 *$ & 31.6 & $69.8 *$ & $28.3 *$ \\
& (stdev) & $(0.9)$ & $(0.7)$ & $(2.6)$ & $(2.5)$ & $(1.2)$ & $(1.5)$ & $(25.0)$ & $(6.8)$ & $(24.9)$ & $(2.5)$ & $(0.6)$ \\
$\mathrm{Fe}(0)$ & $\mathrm{avg}$ & $86.6 *$ & $47.7 *$ & 29.9 & $64.4 *$ & 80.7 & $71.8 *$ & 70.6 & $37.2 *$ & 77.7 & $67.4 *$ & 48.4 \\
& (stdev) & $(0.6)$ & $(2.1)$ & $(6.2)$ & $(0.3)$ & $(0.3)$ & $(0.1)$ & $(7.8)$ & $(0.1)$ & $(5.3)$ & $(1.6)$ & $(1.6)$ \\
\hline
\end{tabular}

“*” identifies a treatment mean concentration that is significantly $(\mathrm{P} \leq 0.05)$ different than the control mean concentration, according to Dunett's Test.

(a) Data used to generate these data are presented in Figure 3 through Figure 6. Ba, Eu and $\mathrm{K}$ are used here as analogs for Ra, Ac, and Tl. The Strongly Sorbing fraction equals the sum of Fractions 3 and 5 of the sequential extraction data.

Table 15. Percentage of Ancillary Constituents Associated with Strongly Sorbing Fraction ( $100-$ Strongly Sorbing Fraction $=\%$ of Source Term That is Potentially Leachable)

\begin{tabular}{lrccccc}
\hline & & $\mathrm{Al}$ & $\mathrm{Fe}$ & $\mathrm{Mn}$ & $\mathrm{P}$ & $\mathrm{Se}$ \\
\hline Control & $\mathrm{avg}$ & 30.7 & 65.6 & 40.8 & 66.2 & 52.1 \\
& (stdev) & $(1.6)$ & $(1.2)$ & $(3.9)$ & $(1.5)$ & $(3.2)$ \\
Apatite-NC & $\mathrm{avg}$ & 25.1 & 62.6 & $34.6 *$ & $11.7 *$ & $72.1 *$ \\
& $($ stdev) & $(4.1)$ & $(0.5)$ & $(1.3)$ & $(0.7)$ & $(9.1)$ \\
Apatite-NC+ $\mathrm{Fe}(0)$ & $\mathrm{avg}$ & $7.1 *$ & $56.6 *$ & 46.3 & $16.0 *$ & 70.4 \\
& (stdev) & $(2.6)$ & $(2.1)$ & $(0.5)$ & $(0.9)$ & $(0.5)$ \\
$\mathrm{Fe}(0)$ & $\mathrm{avg}$ & $5.2 *$ & $39.9 *$ & 39.0 & $57.8 *$ & $72.1 *$ \\
& $($ stdev) & $(0.8)$ & $(0.1)$ & $(1.4)$ & $(1.1)$ & $(2.5)$ \\
\hline
\end{tabular}

“*” identifies a treatment mean concentration that is significantly $(\mathrm{P} \leq 0.05)$ different than the control mean concentration, according to Dunett's Test.

(a) Data used to generate these data are presented in Figure 3 through Figure 6. 
Table 16. Elemental Concentration and Sequential Fractionation of Apatite-NC

\begin{tabular}{lcccccc}
\hline & $\begin{array}{c}\text { Total } \\
\text { Concentration } \\
(\mathrm{mg} / \mathrm{kg})\end{array}$ & $\begin{array}{c}\text { Exchangeable } \\
\text { Fraction } \\
(\%)\end{array}$ & $\begin{array}{c}\text { Amorphous } \\
\text { Fe-oxide } \\
(\%)\end{array}$ & $\begin{array}{c}\text { Crystalline } \\
\text { Fe-oxide } \\
(\%)\end{array}$ & $\begin{array}{c}\text { Organic/Sulfide } \\
\text { Fraction } \\
(\%)\end{array}$ & $\begin{array}{c}\text { Residual } \\
\text { Fraction } \\
(\%)\end{array}$ \\
\hline $\mathrm{Al}$ & 1382 & 0 & 19 & 67 & 1 & 13 \\
$\mathrm{As}$ & 29.3 & 3 & 9 & 28 & 33 & 26 \\
$\mathrm{Ba}^{(\mathrm{a})}$ & 20.4 & 6 & 17 & 12 & 5 & 60 \\
$\mathrm{Co}$ & 0.8 & 4 & 13 & 10 & 13 & 60 \\
$\mathrm{Cr}$ & 76.3 & 1 & 5 & 25 & 5 & 64 \\
$\mathrm{Eu}{ }^{(a)}$ & 0.78 & 0 & 1 & 0 & 7 & 93 \\
$\mathrm{Fe}$ & 2627 & 1 & 6 & 6 & 18 & 69 \\
$\mathrm{Hg}$ & 5.32 & 13 & 1 & 8 & 2 & 76 \\
$\mathrm{~K}^{(a)}$ & 341 & 6 & 5 & 0 & 4 & 85 \\
$\mathrm{Mn}$ & 17 & 9 & 30 & 15 & 13 & 32 \\
$\mathrm{P}$ & $>101,000$ & 1 & 31 & 27 & 15 & 25 \\
$\mathrm{~Pb}$ & 17.6 & 0 & 8 & 11 & 8 & 73 \\
$\mathrm{Se}$ & 156 & 4 & 30 & 21 & 4 & 41 \\
$\mathrm{Sr}$ & 0.51 & 2 & 0 & 21 & 0 & 77 \\
$\mathrm{Th}$ & 0.84 & 1 & 1 & 4 & 1 & 94 \\
$\mathrm{U}$ & 62.1 & 1 & 8 & 7 & 20 & 64 \\
\hline
\end{tabular}

(a) $\mathrm{Ba}, \mathrm{Eu}$, and $\mathrm{K}$ are included as analogs for $\mathrm{Ra}, \mathrm{Ac}$, and $\mathrm{Tl}$, respectively. 


\subsection{INFLUENC E OF SEDIMENT AMENDMENTS ON CALCULATED SOURCE TERM AND KD VALUES}

Desorption distribution coefficient $\left(\mathrm{K}_{\mathrm{d}}\right)$ values were operationally defined as:

$$
K_{d}=\frac{C_{E x c h}+C_{A m F e}+C_{\text {Org / Sulf }}}{C_{A q}}
$$

where $C$ represents concentration, and the subscripts $E x c h, A m F e$, and $\mathrm{Org} / \mathrm{Sulf}$, represent the first, second and fourth fraction of the sequential extractions, respectively, and $A q$ represents the concentration in the aqueous phase collected from the Flooded treatments at the end of the equilibration period. These fractions of the solid phase were selected for two primary reasons: 1) the $K_{d}$ construct assumes a reversible reaction (adsorption rate is the same as the desorption rate) and these fractions most closely approach this condition, and 2) to be conservative (predict a low $\mathrm{K}_{\mathrm{d}}$ value), the total COC solids concentration was not used.

In order to measure an increase of $\mathrm{K}_{\mathrm{d}}$ in the amended treatments, the COC sorbed to the sediment must first desorb and then re-sorb into the immobilizing phase. Thus, if the sediment amendment is working as designed, then the longer the contaminated sediment is in contact with the amendments, the greater proportion of the total COC pool will become immobilized until steady state conditions are obtained. It is likely that steady state conditions were not achieved during the six to seven week duration of this study. Instead, the system was kinetically hindered with respect to several key reactions involving $\mathrm{Fe}(0)$ and apatite stabilization. Thus, the steady state conditions assumed in the operational definition of $\mathrm{K}_{\mathrm{d}}$ (Equation 6), were likely not obtained during the length of this experiment for several important reactions governing the immobilization of the COC. Three processes in particular are known to be very slow, they are:

- reductive dissolution of Fe-oxyhydroxides that may result in the release of some of the COC's into the aqueous phase for subsequent re-adsorption into less available phases in the sediment amendments (applicable to treatments receiving $\mathrm{Fe}(0)$ ), ${ }^{3}$

- diffusion of adsorbed COC's into strongly retained phases, whereby the COC becomes incorporated into the mineral structure through isomorphic substitution (applicable to treatments receiving apatite), and

- desorption of polyvalent ions is generally a kinetically hindered reaction that often takes weeks to months to come to steady state (as compared to adsorption, which general comes to steady state in the order of hours to days) (Stumm and Morgan 1996).

The implications of the system being kinetically hindered is that the $\mathrm{K}_{\mathrm{d}}$ values calculated by Equation 6 are lower than if the $K_{d}$ values had been measured over a longer duration, for instance, after 1 year.

\footnotetext{
${ }^{3}$ In the natural environment, reductive dissolution takes years to come to steady state (Vepraskas 1996).
} 
The following conclusions are based on Table 17:

- The Apatite-NC treatment had significantly greater $\mathrm{K}_{\mathrm{d}}$ values than the Control for Ba, $\mathrm{K}$, and $\mathrm{Sr}$.

- The $\mathrm{Fe}(0)$ treatment had significantly greater $\mathrm{K}_{\mathrm{d}}$ values than the Control for As, Co, $\mathrm{Cr}, \mathrm{Pb}$, and $\mathrm{Th}$.

- The Apatite-NC $+\mathrm{Fe}(0)$ treatment had significantly greater $\mathrm{K}_{\mathrm{d}}$ values than the Control for all COC's except $\mathrm{Hg}$ and U.

- None of the treatments significantly decreased the $\mathrm{K}_{\mathrm{d}}$ values for any COC's (except the $\mathrm{Sr}-\mathrm{K}_{\mathrm{d}}$ value in the $\mathrm{Fe}(0)$ treatment).

All three amendments lowered the $\mathrm{Se} \mathrm{K}_{\mathrm{d}}$ values (which is not a COC, but an ancillary parameter) with respect to the Control.

Potassium showed only a moderate tendency to be retained by apatite and the removal mechanism is likely an ephemeral cation exchange process.

Unfortunately, there was a great deal of variability associated with the $\mathrm{Hg}$, $\mathrm{Sr}$, and $\mathrm{U} \mathrm{K}_{\mathrm{d}}$ measurements. It is not known whether this variability originated from analytical measurements, experimental techniques, or inherent sediment variability. Furthermore, it is very possible that the contaminated sediment had not released a significant amount of $\mathrm{Hg}$ and $\mathrm{U}$ during the 7-week equilibration time to permit a noticeable difference between the Control and the amendments. Wright et al. (1995) reported significant aqueous U removal through the use of the same source of apatite as was used in this experiment, Apatite-NC. Kaplan et al. (2001) previously reported $\mathrm{Hg} \mathrm{K} \mathrm{d}_{\mathrm{d}}$ values with $\mathrm{Fe}(0)$ between $1364 \pm 117 \mathrm{~mL} / \mathrm{g}$ and $6270 \pm 719 \mathrm{~mL} / \mathrm{g}$. It is not known why these results did not support these previous findings indicating that $\mathrm{Fe}(0)$ and apatite can immobilize $\mathrm{Hg}$ and $\mathrm{U}$, respectively. 
Table 17. Influence of Sediment Amendments on $K_{d}$ Values for Contaminated Sediments

\begin{tabular}{|c|c|c|c|c|c|c|c|c|}
\hline \multirow{2}{*}{$\overline{\text { As }}$} & \multirow{3}{*}{$\begin{array}{r}\text { avg } \\
\text { (stdev) }\end{array}$} & \multirow{3}{*}{$\begin{array}{c}\begin{array}{l}\text { Control } \\
(\mathrm{mL} / \mathrm{g})\end{array} \\
123^{(\mathrm{a})}\end{array}$} & \multicolumn{2}{|c|}{$\begin{array}{c}\text { Apatite-NC } \\
(\mathrm{mL} / \mathrm{g})\end{array}$} & \multicolumn{2}{|c|}{$\begin{array}{c}\text { Apatite-NC + Fe(0) } \\
(\mathrm{mL} / \mathrm{g})\end{array}$} & \multicolumn{2}{|l|}{$\begin{array}{c}\mathrm{Fe}(0) \\
(\mathrm{mL} / \mathrm{g})\end{array}$} \\
\hline & & & 113 & & 333 & $*$ & 367 & * \\
\hline & & & (10) & & (31) & & (6) & \\
\hline \multirow[t]{2}{*}{$\mathrm{Ba}^{(\mathrm{b})}$} & avg & 94 & 154 & $*$ & 158 & $*$ & 96 & \\
\hline & (stdev) & (1) & (2) & & (2) & & (12) & \\
\hline \multirow[t]{2}{*}{ Co } & avg & 110 & 244 & & 436 & $*$ & 524 & * \\
\hline & (stdev) & (29) & (41) & & (45) & & (78) & \\
\hline \multirow[t]{2}{*}{$\mathrm{Cr}$} & avg & 15014 & 18463 & & 32094 & $*$ & 48353 & * \\
\hline & (stdev) & (1524) & (2844) & & (867) & & (4998) & \\
\hline \multirow[t]{2}{*}{$\mathrm{Ce}^{(\mathrm{b})}$} & avg & 53.3 & 363 & & 552 & $*$ & 298 & \\
\hline & (stdev) & (1.8) & (158) & & (109) & & (25) & \\
\hline \multirow[t]{2}{*}{$\mathrm{Fe}$} & avg & 43 & 59 & & 109 & & 92 & \\
\hline & (stdev) & (7.5) & (4.6) & & (35.1) & & (4.7) & \\
\hline \multirow[t]{2}{*}{$K^{(b)}$} & avg & 8.2 & 20.7 & $*$ & 16.2 & & 13.4 & \\
\hline & (stdev) & (5.7) & $(0.9)$ & & $(0.3)$ & & $(1.5)$ & \\
\hline \multirow[t]{2}{*}{$\mathrm{Pb}$} & avg & 2377 & 16090 & & 30210 & * & 26575 & * \\
\hline & (stdev) & (192) & (11750) & & (9878) & & (3135) & \\
\hline \multirow[t]{2}{*}{$\mathrm{Se}$} & avg & 344 & 92 & $*$ & 152 & $*$ & 185 & * \\
\hline & (stdev) & (66) & (55) & & (12) & & (10) & \\
\hline \multirow[t]{2}{*}{$\mathrm{Sr}$} & avg & 27 & 154 & $*$ & 150 & * & 16 & * \\
\hline & (stdev) & (2) & (25) & & (29) & & (2) & \\
\hline \multirow[t]{2}{*}{ Th } & avg & 706 & 2251 & & 3414 & $*$ & 6046 & * \\
\hline & (stdev) & (601) & (380) & & (848) & & (1044) & \\
\hline \multirow[t]{2}{*}{ U } & avg & 1239 & 975 & & 1316 & & 1547 & \\
\hline & (stdev) & (540) & (599) & & (369) & & (188) & \\
\hline \multirow[t]{2}{*}{$\mathrm{Hg}^{(\mathrm{c})}$} & avg & 383 & 339 & & 174 & & 101 & \\
\hline & (stdev) & (164) & (103) & & (49) & & $(355)$ & \\
\hline
\end{tabular}

(a) $\mathrm{K}_{\mathrm{d}}=$ distribution coefficient, operationally defined in Equation 6. Importantly, several of these constituents may be better represented by the solubility construct, but for ease of data presentation and comparison, only $\mathrm{K}_{\mathrm{d}}$ values are presented. Experiment did not reach steady state and therefore are lower values than is expected in situ.

(b) $\mathrm{Ba}, \mathrm{Ce}$, and $\mathrm{K}$ are used here as analogs for $\mathrm{Ra}, \mathrm{Ac}$, and $\mathrm{Tl}$.

(c) Due to analytical interference with the $\mathrm{Hg}$ measurement of the pore water solution collected from the equilibrated solutions, $\mathrm{Hg} \mathrm{K}_{\mathrm{d}}$ values were calculated with the $\mathrm{Hg}$ aqueous concentrations measured in the first leachates collected from the Wet/Dry-Cycled Treatments. * identifies a treatment mean concentration that is significantly $(\mathrm{P} \leq 0.05)$ different than the control mean concentration, according to Dunett's Test. 


\subsection{CONCLUS IONS}

Several parameters were measured to evaluate the effectiveness of the sediment amendments to sequester COC's. Among these parameters were the COC concentrations in sediment leachate and sequential extractions. Four metrics were calculated from these measurements, the Flooded treatment leachates, the Wet/Dry-Cycled leachates, \%-COC Immobilized (inversely related to \% Potential Leachable Source Term), and COC K $\mathrm{d}_{\mathrm{d}}$ Values. Perhaps the Flooded treatment leachate data is the single best parameter to use to evaluate the efficacy of the sediment amendments. It indicates that the Apatite- $\mathrm{NC}+\mathrm{Fe}(0)$ treatment was the best overall treatment and chemically behaved like the sum of the individual $\mathrm{Fe}(0)$ and Apatite-NC amendments (Table 18). $\mathrm{The} \mathrm{Fe}(0)$ treatment tended to remove more different $\mathrm{COC}$ than either type of apatite. The Apatite-NC + $\mathrm{Fe}(0)$ treatment significantly lowered the $\mathrm{COC}$ leaching for all elements except $\mathrm{Cr}, \mathrm{Sr}$, Th, and $\mathrm{U}$ (Table 18). There was little difference between the COC concentrations in the Wet/Dry-Cycled treatments and the Controls because the reduced moisture concentration slowed down many of the important reactions responsible for amendment COC sequestration (Table 18).

The $K_{d}$ values calculated for this report provide a less direct measure of the efficacy of the treatments and require additional assumptions, but have the distinct advantage over the other parameters in that they can be used directly in risk modeling and are easy to understand. The $\mathrm{K}_{\mathrm{d}}$ values for the combined Apatite- $\mathrm{NC}+\mathrm{Fe}(0)$ treatments were significantly greater than the Controls for 8 of the $11 \mathrm{COC}$, all except $\mathrm{Tl}, \mathrm{Hg}$, and $\mathrm{U}$. Uranium concentrations in the contaminated sediment were near that of background, therefore the fact that little enhanced sequestration was measured in the presence of the amendments is not surprising. Previous work conducted on SRS and elsewhere indicate that both $\mathrm{Hg}$ and $\mathrm{U}$ should be readily removed from the aqueous phase in the presence of $\mathrm{Fe}(0)$ and/or apatite (Wright et al. 1995, Kaplan et al. 2001, Rakovan et al. 2002, Fuller et al. 2002).

The \% Potential Leachable Source Term (Equation 5) is important in that it provides a sound estimate of the COC fraction that can leach from the sediments. This can be thought of as the true source term, as compared to the total COC pool, which may require that very strong bonds (e.g., mineral structural bonds) be broken before a COC enters the groundwater. As Table 18 indicates, the Apatite- $\mathrm{NC}+\mathrm{Fe}(0)$ treatment significantly immobilized (reduced the source term) $\mathrm{As}, \mathrm{Co}, \mathrm{Hg}$, and Th compared to the Control. It should be noted that the relatively short duration of these experiments, 6 to 7 weeks, likely produced results that would underestimate the actual magnitude of immobilization that a longer-term experiment would produce.

Two very different sources of apatite were evaluated by the leach test. Both types of apatite have been used to remediate other contaminated sites, including mining sites and DOE sites (Moody and Wright 1995, Wright et al. 1995, www.pimsnw.com). Apatite-NC is a mined mineral, with an appreciably lower solubility than the Apatite-II, a biogenic material. As is the case with other sources of mined apatite, Apatite-NC had especially high concentrations of contaminants, including $\mathrm{As}, \mathrm{Cr}, \mathrm{Hg}, \mathrm{Pb}$, and $\mathrm{U}$. These high concentrations are indicative of the ability of this material to sequester these constituents over geologic timeframes. Sequential extractions of the Apatite-NC showed that $>86 \%$ of these COC's were strongly bound by the mineral structure and 
were not likely to leach into the pore water. The presence of $\mathrm{As}$ and $\mathrm{Hg}$ in the Apatite-NC may be a potential problem, but one that can be resolved by including $\mathrm{Fe}(0)$ with the Apatite-NC; the $\mathrm{Fe}(0)$ readily removes As and $\mathrm{Hg}$ through reduction.

In conclusion, these data show that the addition of both $\mathrm{Fe}(0)$ and apatite to the TNX OD sediment will greatly stabilize most of the COC's. Together, these amendments will increase the $\mathrm{K}_{\mathrm{d}}$ values and decrease the potentially leachable fraction of the source term for a majority of the COC's. One concern was the leaching of As (and possibly Hg) from the apatite itself, but this potential problem may be offset by including $\mathrm{Fe}(0)$. Thallium showed only a moderate tendency to be retained by apatite and the removal mechanism is likely cation exchange, a weak removal mechanism. 
Table 18. Summary of Sediment Amendments Effects on Various COC-Concentration Parameters With Respect to the Controls ("L" = Significantly Lower, "H" = Significantly Higher, Empty = No Significant Difference)

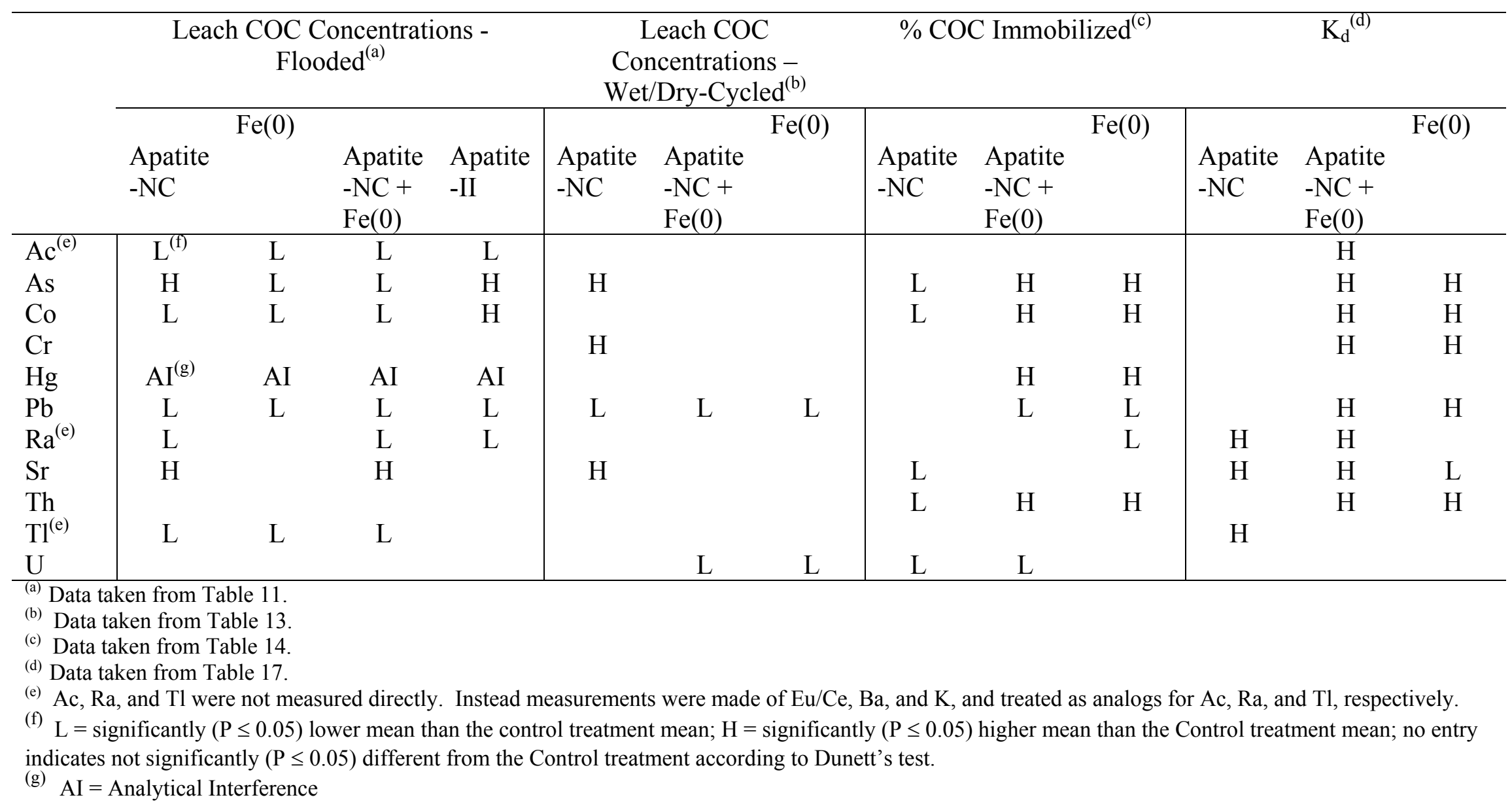




\subsection{REFERENCES}

Appelo, C. A. J., M. J. J. Van Der Weiden, C. Tournassat, and L. Charlet. 2002. Surface Complexation of Ferrous Iron and Carbonate on Ferrihydrite and the Mobilization of Arsenic. Environ. Sci. Technol. 36(14):3096-3103.

Bostick, W. D., R. J. Jarabek, D. A. Bostick, and J. Conca. 1999. Phosphate-Induced Metal Stabilization: Use of Apatite and Bone Char for the Removal of Soluble Radionuclide in Authentic and Simulated DOE Groundwater. Advance in Environmental Research 3: 488-498.

Conca, J. L., N. Lu, G. Parker, B. Moore, A. Adams, J. Wright, and P. Heller. 2000. PIMS Remediation of Metal Contaminated Water and Soils. Proceedings of the Second International Conference on Remediation of Chlorinated and Recalcitrant Compounds. Monterey, CA

Deer, W. A., R. A. Howie, and J. Zussman. 1975. Rock-Forming Minerals. Vol. 5, NonSilicates. John Wiley and Sons, New York.

Eary, L. E., and D. Rai. 1987. Kinetics of Chromium(III) Oxidation to Chromium(VI) by Reaction with Manganese Dioxide. 21:1187-1193.

Fuller, C. C., J. R. Bargar, J. A. Davis, and M. J. Paina. 2002. Mechanisms of Uranium Interactions with Hydroxyapatite: Implications for Groundwater Remediation. Environ. Sci. Technol. 36(2):158-165.

Gilmour, C. C., E. A. Henry, and R. Mitchell. 1992. Sulfate Stimulation of Mercury Methylation in Freshwater Sediments. Environ. Sci. Technol. 26:2281-2287.

Hall, G. E. M., J. E. Vaive, R. Beer, and M. Hoashi. 1996. Selective Leaches Revisited, with Emphasis on the Amorphous Fe Oxyhydroxide Phase Extraction. J. Geochemical Exploration. 56:59-78.

Kaplan, D. I., and S. M. Serkiz. 2000. In-situ Kd Values and Geochemical Behavior for Inorganic and Organic Constituents of Concern at the TNX Outfall Delta. WSRC-TR-99-00488. Westinghouse Savannah River Company, Aiken, SC.

Kaplan, D. I. 2001. Impact of Returning the TNX Outfall Delta to a Wetter Condition on Radionuclide Mobility. WSRC-TR-2001-00081, Rev. 0. Westinghouse Savannah River Company, Aiken, SC.

Kaplan, D. I., A. S. Knox, T. G. Hinton, R. R. Sharitz, B. P. Allen, S. M. Serkiz. 2001. Proofof-Concept of the Phytoimmobilization Technology for TNX Outfall Delta. WSRC-TR-200100032, Rev. 0. Westinghouse Savannah River Company, Aiken, SC. 
Kuo, S. 1996. Phosphorus. In: D. L. Sparks (ed), Methods of Soil Analysis, Part 3 - Chemical Methods. pp. 869 - 919. Soil Science Society of America, Madison, WI.

Melita, N. M. Conklin, and J. Ferrell. 2002. Electrochemical Study of Arsenate and Water Reduction on Iron Media Used for Arsenic Removal from Potable Water. Environ. Sci. Technol. 36(14):3188-3193.

Miller, W. P. and D. M. Miller. 1987. "A Micro-Pipette Method for Soil Mechanical Analysis." Communications In Soil Sci., Plant Anal. 18(1) 1-15.

Moody, T. E., and J. Wright. 1995. Adsorption Isotherms: North Carolina Apatite Induced Precipitation of Lead, Zinc, Manganese and Cadmium from Bunker Hill Soil, BHI-00197, Bechtel Hanford, Inc, Richland WA.

Nelson, d. W., and L. E. Sommers. 1996. Total Carbon, Organic Carbon, and Organic Matter. pp. 961-1010. In: D. H. Sparks (ed.), Methods of Soil Analysis, Part 3, Chemical Methods, Soil Science Society of America and American Society of Agronomy, Madison, Wisconsin.

Rakovan, J., R. J. Reeder, E. J. Elzinga, D. J. Cherniak, C. D. Tait, and D. E. Morris. 2002. Structural Characterization of U(VI) in apatite by X-ray Absorption Spectroscopy. Environ. Sci. Technol. 36(14):3114-3117.

Sass, B. M., and D. Rai. 1987. Solubility of Amorphous Chromium(III)-Iron(III) Hydroxide Solid Solutions. Inorganic Chemistry. 26:2228-2232.

Sparks, D. O. 1996. Methods of Soil Analysis, Part 3 - Chemical Methods. Soil Science Society of America, Inc., Madison, Wisconsin.

Stumm, W., and J. J. Morgan. 1996. Aquatic Chemistry, Chemical Equilibria and Rates in Natural Waters. $3^{\text {rd }}$ Edition. Wiley-Interscience, New York.

Sumner, M. E. and W. P. Miller. 1996. "Cation Exchange Capacity and Exchange Coefficients.” pp.1201-1229. In: D. H. Sparks (ed.), Methods of Soil Analysis, Part 3, Chemical Methods, Soil Science Society of America and American Society of Agronomy, Madison, Wisconsin.

Tessier, A., P. G. C. Campbell, and M. Bisson. 1979. Sequential Extraction Procedure for the Speciation of Particulate Trace Metals. Analytical Chemistry. 51:844-851.

Thomas, G. W. 1996. Soil pH and Soil Acidity. In: D. H. Sparks (ed.) Methods of Soil Analysis, Part 3, Chemical Methods, Soil Science Society of America and American Society of Agronomy, Madison, Wisconsin.

Vepraskas, M. J. 1996. Redoximorphic Features for Identifying Aquic Conditions. Technical Bulletin 301. North Carolina Agricultural Research Service, North Carolina State University, Raleigh, NC. 
WSRC (Westinghouse Savannah River Company). 1999. RFI/RI with BRA for the TNX Outfall Delta, Lower Discharge Gully and Swamp Operable Unit. WSRC-RP-98-4158, Rev. 0. Westinghouse Savannah River Company, Aiken, SC.

Winer, B. J. 1971. Statistical Principles in Experimental Design. McGraw-Hill, Inc.

Wright, J. 1990. Conodont Apatite: Structure and Geochemistry. In: J. Carter (Ed.), Metazoan Biomineralization: Patterns, Processes and Evolutionary Trends. Pp. 445-459, Van Nostrand Reinhold, New York.

Wright, J. V., L. M. Peurrung, T. E. Moody, J. L. Conca, X. Chen, P. P. Didzerekis, and E. Wyse. 1995. In Situ Immobilization of Heavy Metals: Apatite Mineral Formations. Technical Report to the Strategic Environmental Research and Development Program, Department of Defense, Pacific Northwest National Laboratory, Richland, WA p. 154. 
WSRC-TR-2002-00370, Rev. 0

Page 47

\subsection{APPENDIX A: ADDITIONAL DATA}


Appendix Table 1. Pore Water Chemistry of Leachate at End of Experiment: Eh, $\mathrm{O}_{2}$, $\mathrm{pH}$ and Conductivity

\begin{tabular}{llcccc}
\hline Trt ID & Amendment & Eh $(\mathrm{mV})$ & $\mathrm{O}_{2}(\mathrm{mg} / \mathrm{L})$ & $\mathrm{pH}$ & $\begin{array}{c}\text { Conductivity } \\
(\mu \mathrm{S} / \mathrm{cm})\end{array}$ \\
\hline 301 & Control-Flooded & -136 & 0.06 & 5.54 & \\
302 & Control-Flooded & -128 & 0.17 & 5.94 & 516 \\
303 & Control-Flooded & -172 & 0.06 & 5.88 & 494 \\
304 & Apatite-Flooded & -176.5 & 0.04 & 6.52 & 608 \\
305 & Apatite-Flooded & -172.6 & 0.04 & 6.68 & 623 \\
306 & Apatite-Flooded & -178.6 & 0.05 & 6.7 & 585 \\
307 & Apatite+Fe(0)-Flooded & -182.9 & 0.05 & 6.73 & 552 \\
308 & Apatite+Fe(0)-Flooded & -187.8 & 0.07 & 6.7 & 575 \\
309 & Apatite+Fe(0)-Flooded & -185.9 & 0.06 & 6.65 & 587 \\
310 & Fe(0)-Flooded & -179.4 & 0.05 & 6.26 & 442 \\
311 & Fe(0)-Flooded & -168.8 & 0.04 & 6.32 & 441 \\
312 & Fe(0)-Flooded & -171.6 & 0.23 & 6.28 & 465 \\
313 & Control-Wet/Dry & 273.6 & 6 & 4.36 & 281 \\
314 & Control-Wet/Dry & 294.6 & 5.5 & 4.44 & 252 \\
315 & Control-Wet/Dry & 291.2 & 5.06 & 4.58 & 257 \\
316 & Apatite-Wet/Dry & 209.4 & 4.43 & 5.04 & 578 \\
317 & Apatite-Wet/Dry & 207.4 & 4.36 & 5.33 & 442 \\
318 & Apatite-Wet/Dry & 226.5 & 4.08 & 5.22 & 445 \\
319 & Apatite+Fe(0)-Wet/Dry & 203.2 & 3.37 & 5.49 & 327 \\
320 & Apatite+Fe(0)-Wet/Dry & 191.7 & 3.16 & 5.75 & 336 \\
321 & Apatite+Fe(0)-Wet/Dry & 185.2 & 3.43 & 5.78 & 322 \\
322 & Fe(0)-Wet/Dry & 290.8 & 3.58 & 5.19 & 208 \\
323 & Fe(0)-Wet/Dry & 193 & 3.29 & 5.36 & 172 \\
324 & Fe(0)-Wet/Dry & 206.6 & 3.53 & 5.33 & 192 \\
\hline & & & & \\
\hline
\end{tabular}


WSRC-TR-2002-00370, Rev. 0

Page 49

Appendix Table 2. Pore Water Chemistry of Leachate at End of Experiment: ICP-MS data $(\mu \mathrm{g} / \mathrm{L})$

\begin{tabular}{|c|c|c|c|c|c|c|c|c|c|c|c|c|}
\hline Trt ID & Amendment & $\mathrm{Al}$ & $\mathrm{Cr}$ & $\mathrm{Co}$ & As & $\mathrm{Sr}$ & $\mathrm{Ba}$ & $\mathrm{Hg}$ & $\mathrm{Pb}$ & $\mathrm{Th}$ & $\mathrm{U}$ & $\mathrm{Ce}$ \\
\hline 301 & Control-Flooded & 225.35 & 2.65 & 20.9 & 17.167 & 131.86 & 451.58 & AI & 6.913 & 24.75 & 1.5016 & 62.889 \\
\hline 302 & Control-Flooded & 249.24 & 2.1901 & 13.452 & 16.812 & 98.775 & 430.81 & AI & 7.8634 & 5.638 & 0.87663 & 59.946 \\
\hline 303 & Control- Flooded & 196.9 & 3.6633 & 27.719 & 21.695 & 135.5 & 504.09 & 10.402 & & & 3.1746 & 25.465 \\
\hline 304 & Apatite-Flooded & 69.781 & 1.787 & 7.0231 & 21.619 & 364.44 & 284.67 & AI & 2.5662 & 3.5557 & 7.0663 & 13.016 \\
\hline 305 & Apatite-Flooded & 60.229 & 2.2416 & 8.5151 & 24.192 & 308.36 & 272.67 & AI & 0.82285 & 2.5114 & 2.6375 & 6.8842 \\
\hline 306 & Apatite- Flooded & 72.733 & 3.325 & 13.051 & 23.197 & & 307.75 & 0 & 1.0082 & & 7.8191 & 8.908 \\
\hline 307 & $\mathrm{Ap}+\mathrm{Fe}(0)$-Flooded & 51.032 & 1.6872 & 6.2394 & 8.2013 & 325.2 & 272.67 & AI & 0.82285 & 2.5114 & 2.6375 & 6.8842 \\
\hline 308 & $\mathrm{Ap}+\mathrm{Fe}(0)$-Flooded & 60.799 & 1.6221 & 5.7122 & 7.3085 & 326.73 & 284.51 & AI & 0.57665 & 1.7004 & 3.4779 & 5.1978 \\
\hline 309 & $\mathrm{Ap}+\mathrm{Fe}(0)-$ Flooded & 53.638 & 2.4842 & 8.9383 & 8.2217 & 225.1 & 298.8 & 0 & 0.62168 & & 5.0919 & 4.1978 \\
\hline 310 & $\mathrm{Fe}(0)$-Flooded & 54.209 & 1.5794 & 5.5769 & 6.4433 & 129.3 & 437.23 & AI & 0.67679 & 1.0901 & 1.0432 & 11.691 \\
\hline 311 & $\mathrm{Fe}(0)$-Flooded & 45.46 & 1.6458 & 6.9333 & 5.9856 & 123.36 & 409.26 & AI & 0.88068 & 1.0268 & 0.95978 & 10.37 \\
\hline 312 & Fe(0)- Flooded & 39.109 & 2.2464 & 6.1354 & 5.2921 & 122.04 & 405.46 & 0 & 0.70928 & & 1.2095 & 8.6073 \\
\hline 325 & Apatite-II- Flooded & 31.322 & 2.6545 & 45.263 & 54.07 & 115.29 & 204.72 & 6.2729 & 0.86469 & 38.641 & 1.584 & 1.7667 \\
\hline 326 & Apatite-II- Flooded & 32.493 & 1.95 & 34.934 & 42.057 & 109.06 & 168.61 & 2.2114 & 1.1066 & 6.1459 & 0.44405 & 1.1203 \\
\hline 327 & Apatite-II- Flooded & 24.78 & 2.358 & 38.944 & 45.902 & 103.06 & 184.86 & 1.5035 & 0.70406 & 4.2815 & 0.61204 & 0.94542 \\
\hline 313 & Control-Wet/Dry & 313.93 & 2.1612 & 4.3845 & 0.94685 & 32.491 & 66.442 & AI & 1.5658 & 0.92879 & 0.33819 & 3.7893 \\
\hline 314 & Control-Wet/Dry & 319.63 & 1.7167 & 10.529 & 0.982 & 35.774 & 129.72 & AI & 1.6379 & 0.64277 & 0.4727 & 18.26 \\
\hline 315 & Control- Wet/Dry & 287.19 & 2.3111 & 11.19 & 1.0084 & 29.292 & 122.06 & 0 & 2.1497 & & 0.57152 & 16.795 \\
\hline 316 & Apatite-Wet/Dry & 550.22 & 4.2758 & 6.1742 & 2.7814 & 336.34 & 138.31 & AI & 1.0279 & 1.4521 & 0.22531 & 18.591 \\
\hline 317 & Apatite-Wet/Dry & 419.55 & 3.2628 & 3.4178 & 2.2497 & 219.88 & 90.929 & AI & 0.73444 & 0.96314 & 0.30525 & 12.541 \\
\hline 318 & Apatite- Wet/Dry & 454.27 & 3.7064 & 2.9808 & 2.022 & 191.45 & 83.591 & 3.518 & 0.80866 & & 0.42074 & 10.511 \\
\hline 319 & $\operatorname{Ap}+F e(0)-W e t / D r y$ & 827.15 & 1.2303 & 0.85699 & 1.0738 & 96.84 & 47.053 & AI & 0.82201 & 0.73438 & 0.1883 & 3.384 \\
\hline 320 & $\mathrm{Ap}+\mathrm{Fe}(0)-\mathrm{Wet} /$ Dry & 905.09 & 1.1514 & 0.78571 & 1.0315 & 86.988 & 41.75 & AI & 0.59735 & 0.70384 & 0.15292 & 2.4758 \\
\hline 321 & $\mathrm{Ap}+\mathrm{Fe}(0)-$ Wet/Dry & & 2.0076 & 1.2531 & 1.4324 & 87.858 & 49.045 & 0.49748 & 1.1788 & & 0.24639 & 2.9607 \\
\hline 322 & Fe(0)-Wet/Dry & 324.79 & 0.92928 & 0.78147 & 0.72814 & 17.043 & 29.775 & AI & 0.68071 & 0.30977 & 0.08889 & 1.2998 \\
\hline 323 & Fe(0)-Wet/Dry & 280.33 & 0.27238 & 2.2536 & 0.76248 & 11.117 & 59.014 & AI & 0.35443 & 0.18571 & 0.19804 & 4.9323 \\
\hline
\end{tabular}

AI - Analytical Interference 
Appendix Table 3. Pore Water Chemistry of Leachate at End of Experiment: ICP-AES data $(\mu \mathrm{g} / \mathrm{L})$

\begin{tabular}{clrrrrrrr}
\hline Trt ID & Amendment & \multicolumn{1}{c}{$\mathrm{Ca}$} & \multicolumn{1}{l}{$\mathrm{Cr}$} & $\mathrm{Fe}$ & $\mathrm{K}$ & $\mathrm{Na}$ & $\mathrm{P}$ & $\mathrm{Se}$ \\
\hline 301 & Control-Flooded & 12.8 & 0.0168 & 185.7 & 38.5 & & 1.464 & 0.5716 \\
302 & Control-Flooded & 10.95 & 0.0195 & 137.6 & 13.31 & 46.58 & 1.11 & 0.1374 \\
303 & Control-Flooded & 13.58 & 0.0464 & 208 & 9.001 & 25.93 & 1.7 & 0.6802 \\
304 & Apatite-Flooded & 73.68 & 0.001 & 119.4 & 7.728 & 29.95 & 1.216 & 0.7043 \\
305 & Apatite-Flooded & 80.1 & 0.0095 & 125.1 & 7.403 & 28.82 & 1.203 & 0.7126 \\
306 & Apatite-Flooded & 72.76 & 0.0413 & 109.5 & 7.265 & 26.47 & 1.284 & 0.7293 \\
307 & Ap+Fe(0)-Flooded & 59.64 & 0.0054 & 139.1 & 7.566 & 27.25 & 1.203 & 0.6527 \\
308 & Ap+Fe(0)-Flooded & 67.79 & 0.002 & 118.1 & 7.45 & 27.47 & 1.065 & 0.6445 \\
309 & Ap+Fe(0)-Flooded & & 0.0415 & 120 & 7.79 & 26.39 & 1.402 & 0.7695 \\
310 & Fe(0)-Flooded & 15.51 & 0.0059 & 180.9 & 8.285 & 26.13 & 1.329 & 0.533 \\
311 & Fe(0)-Flooded & 14.92 & 0.0051 & 161.9 & 8.03 & 23.68 & 1.334 & 0.4842 \\
312 & Fe(0)-Flooded & 14.81 & 0.0406 & 172.5 & 8.537 & 23.98 & 1.343 & 0.6087 \\
325 & Apatite-II-Flooded & 311.9 & 0.0576 & 218 & 102.8 & 279.6 & 3.347 & 1.748 \\
326 & Apatite-II-Flooded & 327.1 & 0.0618 & 216 & 51.38 & 178.5 & 3.398 & 1.775 \\
327 & Apatite-II-Flooded & 326.3 & 0.0604 & 209.4 & 49.73 & 172.2 & 3.386 & 1.716 \\
313 & Control-Wet/Dry & 6.341 & 0 & 4.812 & 9.492 & 44.42 & 0.5401 & 0.044 \\
314 & Control-Wet/Dry & 3.348 & 0 & 3.417 & 6.104 & 35.88 & 0.2336 & 0.1457 \\
315 & Control-Wet/Dry & 2.369 & 0.0186 & & 4.682 & 30.21 & 0.5861 & 0.0964 \\
316 & Apatite-Wet/Dry & 50.02 & 0.0663 & 1.826 & 8.276 & 56.62 & 1.139 & 0.3754 \\
317 & Apatite-Wet/Dry & 34.81 & 0.0526 & 0.8001 & 6.531 & 43.3 & 0.9845 & 0.2624 \\
318 & Apatite-Wet/Dry & 33.22 & 0.0188 & 0.9635 & 6.64 & 42.07 & 0.8843 & 0.2673 \\
319 & Ap+Fe(0)-Wet/Dry & 16.75 & 0.0224 & 1.237 & 5.346 & 36.11 & 0.5834 & 0.1149 \\
320 & Ap+Fe(0)-Wet/Dry & 15.6 & 0.0215 & 0.9879 & 5.211 & 39.41 & 0.629 & 0.129 \\
321 & Ap+Fe(0)-Wet/Dry & 15.36 & 0.0191 & 1.808 & 5.57 & 35.39 & 0.6983 & 0.164 \\
322 & Fe(0)-Wet/Dry & 4.294 & 0.0133 & 0.8011 & 4.607 & 29.63 & 0.4945 & 0.0443 \\
323 & Fe(0)-Wet/Dry & 1.376 & 0.0137 & 1.335 & 3.131 & 24.69 & 0.3464 & 0.0462 \\
324 & Fe(0)-Wet/Dry & 1.141 & 0.0174 & 1.633 & 3.047 & 27.13 & 0.4944 & 0.0721 \\
\hline & & & & & & &
\end{tabular}


Appendix Table 4. Sequential Extractions of the Control Sediment (2 replicates)

\begin{tabular}{cccccc}
\hline & $\begin{array}{c}\text { Fraction 1 } \\
\text { (avg \%-wt) }\end{array}$ & $\begin{array}{c}\text { Fraction 2 } \\
\text { (avg \%-wt) }\end{array}$ & $\begin{array}{c}\text { Fraction 3 } \\
\text { (avg \%-wt) }\end{array}$ & $\begin{array}{c}\text { Fraction 4 } \\
\text { (avg \%-wt) }\end{array}$ & $\begin{array}{c}\text { Fraction 5 } \\
\text { (avg \%-wt) }\end{array}$ \\
\hline $\mathrm{Ba}^{(\mathrm{a})}$ & 29.2 & 11.9 & 15.0 & 9.9 & 33.9 \\
$\mathrm{Co}$ & 21.0 & 38.8 & 7.4 & 12.6 & 20.3 \\
$\mathrm{Cr}$ & 9.4 & 30.0 & 2.0 & 23.7 & 34.9 \\
$\mathrm{Eu}$ & 43.8 & 34.8 & 3.9 & 1.4 & 16.1 \\
$\mathrm{~K}$ & 28.0 & 10.7 & 0.0 & 12.5 & 48.8 \\
$\mathrm{~Pb}$ & 8.7 & 26.9 & 2.2 & 6.8 & 55.4 \\
$\mathrm{Sr}$ & 3.2 & 23.8 & 1.1 & 7.5 & 64.4 \\
$\mathrm{Th}$ & 28.2 & 1.7 & 29.5 & 28.2 & 12.5 \\
$\mathrm{U}$ & 30.1 & 14.7 & 10.0 & 6.1 & 39.2 \\
$\mathrm{Fe}$ & 7.1 & 22.8 & 32.4 & 4.5 & 33.2 \\
$\mathrm{Mn}$ & 37.5 & 14.0 & 18.7 & 7.6 & 22.1 \\
$\mathrm{P}$ & 3.2 & 6.3 & 25.7 & 24.3 & 40.5 \\
& & & & & \\
& $($ stdev \%-wt) & (stdev \%-wt) & $($ stdev \%-wt) & (stdev \%-wt) & $($ stdev \%-wt) \\
$\mathrm{Ba}$ & 1.4 & 0.7 & 1.2 & 0.1 & 0.3 \\
$\mathrm{Co}$ & 3.8 & 4.5 & 1.4 & 1.4 & 28.7 \\
$\mathrm{Cr}$ & 4.2 & 2.8 & 0.8 & 0.8 & 7.8 \\
$\mathrm{Eu}$ & 1.6 & 0.3 & 0.1 & 0.1 & 2.9 \\
$\mathrm{~K}$ & 1.1 & 0.0 & 0.2 & 0.2 & 14.0 \\
$\mathrm{~Pb}$ & 0.5 & 1.4 & 0.4 & 0.4 & 12.2 \\
$\mathrm{Sr}$ & 3.8 & 1.6 & 0.7 & 0.7 & 8.6 \\
$\mathrm{Th}$ & 0.3 & 12.1 & 1.6 & 1.6 & 1.0 \\
$\mathrm{U}$ & 1.0 & 1.4 & 0.0 & 0.0 & 1.3 \\
$\mathrm{Fe}$ & 0.4 & 1.7 & 0.1 & 0.1 & 1.2 \\
$\mathrm{Mn}$ & 0.5 & 2.8 & 0.2 & 0.2 & 3.4 \\
$\mathrm{P}$ & 0.3 & 1.3 & 0.2 & 0.2 & 0.9 \\
\hline $\mathrm{Ba}$ & 0.3 & &
\end{tabular}

(a) $\mathrm{Ba}$ is used in this study as an analog for $\mathrm{Ra}, \mathrm{Eu}$ for $\mathrm{Ac}$, and $\mathrm{K}$ for $\mathrm{Tl}$. 
Appendix Table 5. Sequential Extractions of the Apatite-NC Amended Sediment (2 replicates)

\begin{tabular}{|c|c|c|c|c|c|}
\hline & $\begin{array}{l}\text { Fraction } 1 \\
\text { (avg \%-wt) }\end{array}$ & $\begin{array}{l}\text { Fraction } 2 \\
\text { (avg \%-wt) }\end{array}$ & $\begin{array}{l}\text { Fraction } 3 \\
\text { (avg \%-wt) }\end{array}$ & $\begin{array}{l}\text { Fraction } 4 \\
\text { (avg \%-wt) }\end{array}$ & $\begin{array}{l}\text { Fraction } 5 \\
\text { (avg \%-wt) }\end{array}$ \\
\hline $\mathrm{Ba}^{(\mathrm{a})}$ & 26.0 & 19.4 & 15.1 & 8.5 & 30.9 \\
\hline $\mathrm{Co}$ & 33.1 & 48.8 & 0.2 & 17.9 & 0.0 \\
\hline $\mathrm{Cr}$ & 13.2 & 36.8 & 0.0 & 21.8 & 28.2 \\
\hline $\mathrm{Eu}$ & 36.9 & 45.8 & 2.8 & 1.1 & 13.4 \\
\hline $\mathrm{K}$ & 27.1 & 12.2 & 0.0 & 15.2 & 45.6 \\
\hline $\mathrm{Pb}$ & 16.5 & 38.3 & 0.4 & 6.9 & 37.9 \\
\hline $\mathrm{Sr}$ & 1.5 & 88.7 & 0.0 & 0.8 & 9.0 \\
\hline Th & 23.4 & 2.9 & 15.0 & 42.3 & 16.4 \\
\hline $\mathrm{U}$ & 19.1 & 49.2 & 9.3 & 4.5 & 17.9 \\
\hline $\mathrm{Fe}$ & 6.8 & 25.9 & 32.0 & 4.8 & 30.6 \\
\hline $\mathrm{Mn}$ & 34.7 & 23.3 & 17.1 & 7.4 & 17.5 \\
\hline \multirow[t]{2}{*}{$\mathrm{P}$} & 0.7 & 84.4 & 7.0 & 3.3 & 4.7 \\
\hline & (stdev $\%$-wt) & (stdev $\%$-wt) & (stdev $\%$-wt) & (stdev $\%$-wt) & $(\operatorname{stdev} \%-w t)$ \\
\hline $\mathrm{Ba}$ & 1.1 & 0.5 & 0.4 & 0.3 & 2.2 \\
\hline $\mathrm{Co}$ & 23.3 & 8.6 & 0.4 & 0.6 & 0.0 \\
\hline $\mathrm{Cr}$ & 12.7 & 3.7 & 0.0 & 0.6 & 3.7 \\
\hline $\mathrm{Eu}$ & 7.7 & 1.3 & 0.8 & 0.1 & 2.7 \\
\hline $\mathrm{K}$ & 9.0 & 2.2 & 0.0 & 1.0 & 4.4 \\
\hline $\mathrm{Pb}$ & 10.4 & 1.6 & 0.8 & 0.2 & 2.9 \\
\hline $\mathrm{Sr}$ & 0.0 & 6.6 & 0.0 & 0.0 & 1.7 \\
\hline Th & 1.3 & 0.2 & 3.0 & 4.3 & 1.5 \\
\hline $\mathrm{U}$ & 0.6 & 7.2 & 1.4 & 0.4 & 2.1 \\
\hline $\mathrm{Fe}$ & 0.8 & 2.7 & 1.5 & 0.0 & 0.4 \\
\hline $\mathrm{Mn}$ & 0.8 & 0.8 & 0.9 & 0.1 & 0.7 \\
\hline $\mathrm{P}$ & 0.2 & 6.9 & 0.3 & 0.1 & 0.2 \\
\hline
\end{tabular}

(a) $\mathrm{Ba}$ is used in this study as an analog for $\mathrm{Ra}, \mathrm{Eu}$ for $\mathrm{Ac}$, and $\mathrm{K}$ for $\mathrm{Tl}$. 
Appendix Table 6. Sequential Extractions of the Apatite-NC + Fe(0) Amended Sediment (2 Replicates)

\begin{tabular}{cccccc}
\hline & $\begin{array}{c}\text { Fraction 1 } \\
\text { (avg \%-wt) }\end{array}$ & $\begin{array}{c}\text { Fraction 2 } \\
\text { (avg \%-wt) }\end{array}$ & $\begin{array}{c}\text { Fraction 3 } \\
\text { (avg \%-wt) }\end{array}$ & $\begin{array}{c}\text { Fraction 4 } \\
\text { (avg \%-wt) }\end{array}$ & $\begin{array}{c}\text { Fraction 5 } \\
\text { (avg \%-wt) }\end{array}$ \\
\hline $\mathrm{Ba}^{(\mathrm{a})}$ & 25.7 & 19.2 & 15.5 & 7.7 & 31.9 \\
$\mathrm{Co}$ & 7.0 & 35.7 & 16.7 & 9.4 & 31.2 \\
$\mathrm{Cr}$ & 3.7 & 26.4 & 40.5 & 15.3 & 14.1 \\
$\mathrm{Eu}$ & 33.2 & 40.8 & 3.8 & 1.0 & 21.2 \\
$\mathrm{~K}$ & 17.0 & 7.0 & 0.0 & 12.0 & 64.0 \\
$\mathrm{~Pb}$ & 4.2 & 35.7 & 3.2 & 3.8 & 53.2 \\
$\mathrm{Sr}$ & 1.0 & 85.0 & 0.0 & 1.0 & 12.0 \\
$\mathrm{Th}$ & 9.5 & 1.5 & 4.3 & 19.2 & 65.5 \\
$\mathrm{U}$ & 16.4 & 50.0 & 6.4 & 5.3 & 22.0 \\
$\mathrm{Fe}$ & 8.7 & 32.4 & 37.3 & 2.3 & 19.3 \\
$\mathrm{Mn}$ & 26.9 & 22.4 & 27.0 & 4.3 & 19.4 \\
$\mathrm{P}$ & 0.5 & 80.1 & 9.8 & 3.5 & 6.2 \\
& & & & & \\
& $($ stdev \%-wt) & (stdev \%-wt) & $($ stdev \%-wt) & (stdev \%-wt) & $($ stdev \%-wt) \\
$\mathrm{Ba}$ & 1.4 & 1.1 & 0.9 & 0.2 & 2.9 \\
$\mathrm{Co}$ & 2.2 & 1.8 & 4.0 & 0.8 & 44.1 \\
$\mathrm{Cr}$ & 1.3 & 2.9 & 3.0 & 0.3 & 20.0 \\
$\mathrm{Eu}$ & 2.0 & 0.8 & 0.3 & 0.1 & 2.7 \\
$\mathrm{~K}$ & 1.1 & 0.6 & 0.0 & 0.3 & 4.0 \\
$\mathrm{~Pb}$ & 0.1 & 1.3 & 0.1 & 0.3 & 4.5 \\
$\mathrm{Sr}$ & 0.0 & 16.7 & 0.2 & 0.0 & 0.4 \\
$\mathrm{Th}$ & 0.2 & 0.0 & 0.2 & 0.5 & 6.2 \\
$\mathrm{U}$ & 0.1 & 6.7 & 0.5 & 0.2 & 2.9 \\
$\mathrm{Fe}$ & 0.2 & 2.1 & 8.9 & 0.1 & 7.3 \\
$\mathrm{Mn}$ & 0.7 & 3.1 & 8.5 & 0.7 & 10.9 \\
$\mathrm{P}$ & 0.0 & 15.1 & 0.3 & 0.0 & 1.5 \\
\hline $\mathrm{Br}$ & 0.0 & &
\end{tabular}

(a) $\mathrm{Ba}$ is used in this study as an analog for $\mathrm{Ra}, \mathrm{Eu}$ for $\mathrm{Ac}$, and $\mathrm{K}$ for $\mathrm{Tl}$. 
Appendix Table 7. Sequential Extractions of the Fe(0) Amended Sediment (2 replicates)

\begin{tabular}{|c|c|c|c|c|c|}
\hline & $\begin{array}{c}\text { Fraction } 1 \\
\text { (avg \%-wt) }\end{array}$ & $\begin{array}{c}\text { Fraction } 2 \\
\text { (avg \%-wt) }\end{array}$ & $\begin{array}{l}\text { Fraction } 3 \\
\text { (avg \%-wt) }\end{array}$ & $\begin{array}{l}\text { Fraction } 4 \\
\text { (avg \%-wt) }\end{array}$ & $\begin{array}{l}\text { Fraction } 5 \\
\text { (avg \%-wt) }\end{array}$ \\
\hline $\mathrm{Ba}^{(\mathrm{a})}$ & 32.8 & 11.9 & 14.4 & 9.1 & 31.7 \\
\hline Co & 8.8 & 31.4 & 18.3 & 4.0 & 37.4 \\
\hline $\mathrm{Cr}$ & 7.8 & 17.5 & 51.8 & 9.7 & 13.2 \\
\hline $\mathrm{Eu}$ & 40.1 & 29.0 & 2.5 & 0.8 & 27.6 \\
\hline $\mathrm{K}$ & 14.6 & 2.9 & 0.0 & 11.0 & 71.5 \\
\hline $\mathrm{Pb}$ & 6.1 & 30.7 & 5.8 & 3.7 & 53.6 \\
\hline $\mathrm{Sr}$ & 1.8 & 16.3 & 0.0 & 3.9 & 77.9 \\
\hline $\mathrm{Th}$ & 12.1 & 1.1 & 3.1 & 19.4 & 64.2 \\
\hline $\mathrm{U}$ & 28.6 & 17.3 & 6.3 & 5.8 & 42.1 \\
\hline $\mathrm{Fe}$ & 16.4 & 42.3 & 30.3 & 1.4 & 9.6 \\
\hline $\mathrm{Mn}$ & 27.8 & 28.8 & 29.4 & 4.3 & 9.7 \\
\hline \multirow[t]{2}{*}{$\mathrm{P}$} & 3.8 & 20.7 & 27.4 & 17.7 & 30.4 \\
\hline & $(\operatorname{stdev} \%-w t)$ & $(\operatorname{stdev} \%-w t)$ & $(\operatorname{stdev} \%-w t)$ & $(\operatorname{stdev} \%-w t)$ & $(\operatorname{stdev} \%-w t)$ \\
\hline $\mathrm{Ba}$ & 0.9 & 6.9 & 3.4 & 0.3 & 0.4 \\
\hline $\mathrm{Co}$ & 3.5 & 6.9 & 5.0 & 1.2 & 2.6 \\
\hline $\mathrm{Cr}$ & 2.1 & 4.5 & 26.3 & 1.6 & 0.5 \\
\hline $\mathrm{Eu}$ & 2.9 & 9.7 & 0.3 & 0.3 & 0.7 \\
\hline $\mathrm{K}$ & 0.7 & 2.7 & 0.0 & 1.2 & 19.9 \\
\hline $\mathrm{Pb}$ & 1.9 & 4.0 & 1.5 & 0.2 & 9.0 \\
\hline $\mathrm{Sr}$ & 0.0 & 295.6 & 0.9 & 0.2 & 2.0 \\
\hline Th & 0.8 & 0.5 & 1.2 & 3.6 & 15.2 \\
\hline $\mathrm{U}$ & 2.7 & 46.5 & 3.3 & 3.1 & 3.9 \\
\hline $\mathrm{Fe}$ & 2.9 & 14.7 & 0.6 & 0.1 & 0.1 \\
\hline $\mathrm{Mn}$ & 1.4 & 10.3 & 4.6 & 0.6 & 0.8 \\
\hline $\mathrm{P}$ & 1.0 & 286.6 & 22.9 & 3.4 & 0.2 \\
\hline
\end{tabular}

(a) $\mathrm{Ba}$ is used in this study as an analog for $\mathrm{Ra}, \mathrm{Eu}$ for $\mathrm{Ac}$, and $\mathrm{K}$ for $\mathrm{Tl}$. 
WSRC-TR-2002-00370, Rev. 0

Page 55

\subsection{APPENDIX B: WORK INSTRUCTIONS FOR THE LABORATORY STUDY}




\title{
Work Instructions for \\ The Laboratory Study of the Effects of Sediment Amendments on Contaminant Immobilization in a TNX Outfall Delta Soil
}

\author{
Dan Kaplan \\ February 5, 2002
}

\section{Objectives}

Determine if additions of commercially available $\mathrm{Fe}(0)$ and apatite to a contaminated TNX sediment can reduce contaminant mobility (extractability).

\section{Materials}

\section{Experimental Set-up}

1. B-5 TNX OD contaminated soil, a non-rad and non-hazardous soil

2. granular $\mathrm{Fe}(0)$

3. North Carolina apatite

4. TNX uncontaminated surface water

5. 12 50-mL Oak Ridge tubes

6. 12 disposable filtration assemblies

\section{Methods}

1. Experimental Design: Completely randomized block design, 3 reps $\mathrm{x} 4$ additives (control, $\mathrm{Fe}(0)$, Apatite, and $\mathrm{Fe}(0)+$ Apatite) x 2 moisture conditions (flooded and simulated cyclic rain events $)=24$ treatments. Label containers as shown in Table 1B. 50-mL Oak Ridge tubes will be used for "flooded" treatments and disposable filtration assemblies will be used for the "wet/dry cycle" treatments.

2. Add 15-g of soil to each tube. Add 0.5-g of appropriate amendments to each tube. For the "Apatite+Fe( $(0)$ treatment" add 1 -g of each. "Controls" receive no amendment.

3. Add 25-mL of uncontaminated surface water to the "flooded" treatments. Cap samples, place in a light-proof box, then place box on slow moving platform shaker.

4. For "wet/dry cycle" treatments, add 25-mL of uncontaminated surface water. Mix well by hand. Let water sit on soil for 1 day, then apply vacuum. With a tiny spatula, stir soil to permit air to dry soil. Repeat water addition 3 working days later using $25-\mathrm{mL}$ water. This $25-\mathrm{mL}$ of water will be composed of the water collected from lower reservoir (recycle water) and make-up water from uncontaminated surface water. The cycle will be 1 day wet, followed by 3 days dry. We will evaluate whether this cycle accomplishes the full drying desired.

5. Terminate equilibration period 4-weeks after initial water addition.

6. To terminate "flooded" samples, immediately after opening cap, filter enough sample to permit rapid measurement of $\mathrm{pH}, \mathrm{O}_{2}$, Eh, and conductivity (measure $\mathrm{O}_{2}$ first to reduce amount of $\mathrm{O}_{2}$ from the air to diffuse back into sample. Reuse sample used in the $\mathrm{O}_{2}$ measurement in the in-line measurements of $\mathrm{pH}$, Eh, and conductivity. Separate the remaining solids from liquids by centrifugation. Save both phases. Pass remaining aqueous through a $0.45-\mu \mathrm{m}$ filter. Acidify $\sim 1 / 2$ sample by adding $0.75-\mu \mathrm{L}$ of Ultrex $\mathrm{HNO}_{3}$ for metal 
analyses. Don't acidify the half of the aqueous sample; it will be used for anion analysis. Label samples: 301pw, 302pw/a, etc... Save moistened solids in tared containers labeled $301 \mathrm{~s}, 302 \mathrm{~s}$, etc... Parafilm or tape caps securely to the containers and store in dark in refrigerator.

7. To terminate "wet/dry cycled" samples, add $25-\mathrm{mL}$ water as if initiating another wet/dry cycle. Shake vigorously to get the soil into suspension. After 1-day contact time, vacuum filter and pass liquids through $0.45-\mu \mathrm{m}$ filter. Rapidly measure $\mathrm{pH}, \mathrm{O}_{2}, \mathrm{Eh}$, and conductivity (again, measure $\mathrm{O}_{2}$ first to reduce amount of $\mathrm{O}_{2}$ diffusing back into sample). Complete the separation of solids from liquid. Acidify $1 / 2$ the aqueous sample by adding $0.75-\mu \mathrm{L}$ Ultrex $\mathrm{HNO}_{3}$. Don't acidify the remaining sample; it will be used for anion analysis. Label samples: $313 \mathrm{pw}, 313 \mathrm{pw} / \mathrm{a}$, etc... Save moistened solids in tared containers labeled 313s, 314 s, etc... Parafilm or tape caps securely to the containers and store in refrigerator in dark. 8. Do 4 step sequential extraction on 2 of the 3 replicated soils, as described below.

Table 1B. Treatment I.D.'s.

\begin{tabular}{|l|l|l|l|}
\hline Treatment ID & Moisture Condition & Amendment & Replicate \\
\hline 301 & Flooded & Control & 1 \\
\hline 302 & & & 2 \\
\hline 303 & & Apatite & 3 \\
\hline 304 & & & 1 \\
\hline 305 & & & 2 \\
\hline 306 & & Apatite and Fe(0) & 3 \\
\hline 307 & & & 1 \\
\hline 308 & & $\mathrm{Fe}(0)$ & 2 \\
\hline 309 & & & 3 \\
\hline 310 & & & 1 \\
\hline 311 & & Control & 2 \\
\hline 312 & & & 3 \\
\hline 313 & Wet/Dry Cycling & 1 \\
\hline 314 & & & 2 \\
\hline 315 & & Apatite & 3 \\
\hline 316 & & & 1 \\
\hline 317 & & & 2 \\
\hline 318 & & Apatite and Fe( $(0)$ & 3 \\
\hline 319 & & & 1 \\
\hline 320 & & & 2 \\
\hline 321 & & Fe(0) & 3 \\
\hline 322 & & & 2 \\
\hline 323 & & & 3 \\
\hline 324 & & & \\
\hline
\end{tabular}




\section{Sequential Extraction Method}

\section{Fraction 1: Exchangeable}

1. To $1 \mathrm{~g}$ of wet sample (or dry sample) in a $50 \mathrm{ml}$ screw-cap centrifuge tube, add $20 \mathrm{ml}$ of 1.0 $\mathrm{M} \mathrm{CH} 3 \mathrm{COONa}$ (sodium acetate) at $\mathrm{pH} 5$ and cap.

2. Vortex contents for 5-10 s and place in a horizontal shaker for $6 \mathrm{~h}$.

3. Centrifuge for $10 \mathrm{~min}$. at $2800 \mathrm{rpm}$ and decant supernatant liquid into a labeled test-tube. Rinse residue with $5 \mathrm{ml}$ of DI water, vortex and centrifuge again; do this twice and add supernatant rinses to the test-tube. Make up to the $30 \mathrm{ml}$ mark and analyze.

4. Carry out a second $20 \mathrm{ml} 1 \mathrm{M} \mathrm{CH}_{3} \mathrm{COONa}$ leach of the residue, repeating steps 2 and 3.

Table 2B. Weights used in exchangeable fraction.

\begin{tabular}{|l|l|l|l|l|l|}
\hline ID\# & $\begin{array}{l}\text { Sediment } \\
\text { Description }\end{array}$ & Rep & $\begin{array}{l}\text { Centrifuge } \\
\text { tare wt. (g) }\end{array}$ & $\begin{array}{l}\text { Tare + sed. wet wt. at start of } \\
\text { Exchangeable fraction (g) }\end{array}$ & $\begin{array}{l}\text { Tare + wet sed. + extract wt. } \\
\text { for exchangeable fraction (g) }\end{array}$ \\
\hline 301 & Flooded/Control & 1 & & & \\
\hline 302 & & 2 & & & \\
\hline 304 & Flooded/Apatite & 1 & & & \\
\hline 305 & & 2 & & & \\
\hline 307 & Flooded/Ap\&Fe(0) & 1 & & & \\
\hline 308 & & 2 & & & \\
\hline 310 & Flooded/Fe(0) & 1 & & & \\
\hline 311 & & 2 & & & \\
\hline 313 & Wet-Dry/Control & 1 & & & \\
\hline 314 & & 2 & & & \\
\hline 316 & Wet-Dry/Apatite & 1 & & & \\
\hline 317 & & 2 & & & \\
\hline 319 & Wet-Dry/Ap\&Fe(0) & 1 & & & \\
\hline 320 & & 2 & & & \\
\hline 322 & Wet-dry/Fe(0) & 1 & & & \\
\hline 323 & & 2 & & & \\
\hline
\end{tabular}




\section{Fraction 2: Amorphous Fe oxyhydroxide}

1. To the residue from step 4 of exchangeable fraction, add $20 \mathrm{~mL}$ of $0.25 \mathrm{M} \mathrm{NH}_{2} \mathrm{OH} \mathrm{HCl}$ in $0.25 \mathrm{M} \mathrm{HCl}$, cap and vortex for $5-10 \mathrm{~s}$.

2. Place in a water bath at $60^{\circ} \mathrm{C}$ for $2 \mathrm{~h}$ with cap loosened. Every $30 \mathrm{~min}$., cap tightly and vortex the contents.

3. Centrifuge for $10 \mathrm{~min}$. and decant supernatant liquid into a labeled test-tube. Rinse residue with $5 \mathrm{ml}$ of DI water, vortex and centrifuge again; do this twice and add supernatant rinses to the test-tube. Make up to the $30 \mathrm{~mL}$ mark and analyze.

4. Carry out a second $0.25 \mathrm{M} \mathrm{NH}_{2} \mathrm{OH} \mathrm{HCl}$ leach of the residue, but heat for only 30 minutes. Repeat step 3.

\section{Fraction 3: Crystalline Fe oxide}

1. To the residue from step 4 of amorphous Fe oxyhydroxide, add $30 \mathrm{ml}$ of $1.0 \mathrm{M} \mathrm{NH}_{2} \mathrm{OH}$ $\mathrm{HCl}$ in $25 \% \mathrm{CH}_{3} \mathrm{COOH}$, cap and vortex for 5-10 s.

2. Place in a water bath at $90{ }^{\circ} \mathrm{C}$ for $3 \mathrm{~h}$ with cap on tightly. Vortex contents every 20 minutes.

3. Centrifuge for $10 \mathrm{~min}$. and decant supernatant liquid into a labeled test-tube. Rinse residue with $10 \mathrm{ml}$ of $25 \% \mathrm{CH}_{3} \mathrm{COOH}$, vortex and centrifuge again; do this twice and add supernatant rinses to the test-tube. Make up to the $50 \mathrm{ml}$ mark and analyze

4. Carry out a second $1.0 \mathrm{M} \mathrm{NH}_{2} \mathrm{OH} \mathrm{HCl}$ leach of the residue but heat for only $1.5 \mathrm{~h}$. Then repeat step 3.

\section{Fraction 4: Organic/Sulfide}

1. To the residue from step 4 of crystalline Fe oxide, add $3 \mathrm{ml}$ of $0.02 \mathrm{M} \mathrm{HNO}_{3}$ and $5 \mathrm{~mL}$ of $30 \% \mathrm{H}_{2} \mathrm{O}_{2}$ adjusted to $\mathrm{pH} 2$ with $\mathrm{HNO}_{3}$, and allow the suspension to digest at least one hour at room temperature (or until it stops bubbling). The mixture will be heated at $80^{\circ} \mathrm{C}$ for $2 \mathrm{~h}$ with occasional agitation.

2. A second $3 \mathrm{ml}$ aliquot of $30 \%$ of $\mathrm{H}_{2} \mathrm{O}_{2}\left(\mathrm{pH} 2\right.$ with $\left.\mathrm{HNO}_{3}\right)$ is added and the suspension is allowed to digest at least one hour at room temperature (or until it stops bubbling). The mixture will be heated at $80^{\circ} \mathrm{C}$ for $2 \mathrm{~h}$ with occasional agitation.

3. Add $5 \mathrm{ml}$ of $3.2 \mathrm{M} \mathrm{NH}_{4} \mathrm{OAc}$ in $20 \%(\mathrm{v} / \mathrm{v}) \mathrm{HNO}_{3}$ and shake for 30 minutes.

4. Centrifuge for $10 \mathrm{~min}$. and decant supernatant liquid into a labeled test-tube. Rinse residue with $5 \mathrm{ml}$ of DI water, vortex and centrifuge again; do this twice and add supernatant rinses to the test-tube. Make up to the $30 \mathrm{ml}$ mark and analyze.

5. Repeat steps 2,3 , and 4 if necessary. In step 4 add gradually $30 \%$ of $\mathrm{H}_{2} \mathrm{O}_{2}$. 


\section{Fraction 5: Residual}

1. Sub-sample of 0.6 gram (dry) from step 4 of organic/sulfide was digested in the system Star 6 with $\mathrm{HNO}_{3}(10 \mathrm{ml}), \mathrm{H}_{2} \mathrm{SO}_{4}(4.0 \mathrm{ml}), \mathrm{HNO}_{3}(4.5 \mathrm{ml})$, and $\mathrm{HCl}(2 \mathrm{ml})$. Samples were filtered and diluted to $100 \mathrm{ml}$.

\section{Additional Characterization}

The following analyses were be conducted on an un-treated soil.

- $\quad \mathrm{pH}$ (Cathy)

- $\quad$ particle size distribution (Anna)

- $\quad$ total organic carbon (combustion, Anna)

- $\quad$ cation exchange (Cathy)

- Uncontaminated surface water

- $\quad$ Cation/anions: ICP-MS (primary program + Ce, Th, U, and S specialty programs)

+ ICP-ES (31 elements) (UGa, Anna)

- $\quad$ TIC/TOC (UGa, Anna)

- $\quad \mathrm{pH}, \mathrm{EC}, \mathrm{Eh}$, and $\mathrm{O}_{2}$ (Cathy)

Apatite

- $\quad$ Total digestion by STAR 6 program followed by Cation/anions: ICP-MS (primary program $+\mathrm{Ce}$, Th, U, and S specialty programs) + ICP-ES (31 elements) (UGa, Anna)

$\underline{\mathrm{Fe}(0)}$

- $\quad$ Total digestion by STAR 6 program followed by Cation/anions: ICP-MS (primary program $+\mathrm{Ce}$, Th, U, and S specialty programs) + ICP-ES (31 elements) (UGa, Anna)

- Used $\mathrm{Fe}(0)$; at end of experiment, remove some $\mathrm{Fe}(0)$ particles from soil. Rinse soil off particles. Place used $\mathrm{Fe}(0)$ in centrifuge tube containing $\sim 40-\mathrm{mL}$ water. Place tubes on slow moving platform shaker for 2 hours. Pick out $\mathrm{Fe}(0)$ particles. Submit 3 replicates for chemical analysis. (Dan)

- Total digestion by STAR 6 program followed by Cation/anion analyses: ICP-MS (primary program $+\mathrm{Ce}$, Th, U, and S specialty programs) + ICP-ES (31 elements) (Dan)

\section{Chemical Analyses}

Table $3 \mathrm{~b}$ contains the types of analyses to be performed on each sample. 
Table 3B. Samples to be submitted for chemical analyses.

\begin{tabular}{|c|c|c|c|c|}
\hline & Sample ID & Description & Water & Analysis $^{(\mathrm{a})}$ \\
\hline 1 & $301 \mathrm{pw}$ & Control, Pore Water & Flooded & 2 \\
\hline 2 & $301 \mathrm{pw} / \mathrm{a}$ & Control, Pore Water Acidified & Flooded & 1 \\
\hline 3 & 301 exch & Control, Exchangeable & Flooded & 1 \\
\hline 4 & 301org & Control, Organic & Flooded & 1 \\
\hline 5 & $301 \mathrm{Fe}$ & Control, Crystalline Fe-oxide & Flooded & 1 \\
\hline 6 & 301Tot & Control, Total Residue & Flooded & 1 \\
\hline 7 & 302-pw & Control, Pore Water & Flooded & 2 \\
\hline 8 & $302 \mathrm{pw} / \mathrm{a}$ & Control, Pore Water Acidified & Flooded & 1 \\
\hline 9 & 302 exch & Control, Exchangeable & Flooded & 1 \\
\hline 10 & 302org & Control, Organic & Flooded & 1 \\
\hline 11 & $302 \mathrm{Fe}$ & Control, Crystalline Fe-oxide & Flooded & 1 \\
\hline 12 & 302Tot & Control, Total Residue & Flooded & 1 \\
\hline 13 & $304 \mathrm{pw}$ & Apatite, Pore Water & Flooded & 2 \\
\hline 14 & $304 \mathrm{pw} / \mathrm{a}$ & Apatite, Pore Water Acidified & Flooded & 1 \\
\hline 15 & 304exch & Apatite, Exchangeable & Flooded & 1 \\
\hline 16 & 304org & Apatite, Organic & Flooded & 1 \\
\hline 17 & $304 \mathrm{Fe}$ & Apatite, Crystalline Fe-oxide & Flooded & 1 \\
\hline 18 & 304Tot & Apatite, Total Residue & Flooded & 1 \\
\hline 19 & $305 \mathrm{pw}$ & Apatite, Pore Water & Flooded & 2 \\
\hline 20 & $305 \mathrm{pw} / \mathrm{a}$ & Apatite, Pore Water Acidified & Flooded & 1 \\
\hline 21 & 305 exch & Apatite, Exchangeable & Flooded & 1 \\
\hline 22 & 305org & Apatite, Organic & Flooded & 1 \\
\hline 23 & $305 \mathrm{Fe}$ & Apatite, Crystalline Fe-oxide & Flooded & 1 \\
\hline 24 & 305Tot & Apatite, Total Residue & Flooded & 1 \\
\hline 25 & $307 \mathrm{pw}$ & Apatite\&Fe(0), Pore Water & Flooded & 2 \\
\hline 26 & $307 \mathrm{pw} / \mathrm{a}$ & Apatite\&Fe(0), Pore Water Acidified & Flooded & 1 \\
\hline 27 & $307 \mathrm{exch}$ & Apatite\&Fe(0), Exchangeable & Flooded & 1 \\
\hline 28 & 307org & Apatite \&Fe $(0)$, Organic & Flooded & 1 \\
\hline 29 & $307 \mathrm{Fe}$ & Apatite\&Fe(0), Crystalline Fe-oxide & Flooded & 1 \\
\hline 30 & 307Tot & Apatite\&Fe(0), Total Residue & Flooded & 1 \\
\hline 31 & $308 \mathrm{pw}$ & Apatite\&Fe(0), Pore Water & Flooded & 2 \\
\hline 32 & $308 \mathrm{pw} / \mathrm{a}$ & Apatite\&Fe(0), Pore Water Acidified & Flooded & 1 \\
\hline 33 & 308 exch & Apatite\&Fe(0), Exchangeable & Flooded & 1 \\
\hline 34 & 308org & Apatite\&Fe $(0)$, Organic & Flooded & 1 \\
\hline 35 & $308 \mathrm{Fe}$ & Apatite\&Fe(0), Crystalline Fe-oxide & Flooded & 1 \\
\hline 36 & 308Tot & Apatite\&Fe(0), Total Residue & Flooded & 1 \\
\hline 37 & $310 \mathrm{pw}$ & $\mathrm{Fe}(0)$, Pore Water & Flooded & 2 \\
\hline 38 & 310pw/a & $\mathrm{Fe}(0)$, Pore Water acidified & Flooded & 1 \\
\hline 39 & 310 exch & $\mathrm{Fe}(0)$, Exchangeable & Flooded & 1 \\
\hline 40 & 310org & $\mathrm{Fe}(0)$, Control, Organic & Flooded & 1 \\
\hline 41 & $310 \mathrm{Fe}$ & $\mathrm{Fe}(0)$, Control, Crystalline Fe-oxide & Flooded & 1 \\
\hline 42 & 310Tot & $\mathrm{Fe}(0)$, Control, Total Residue & Flooded & 1 \\
\hline 43 & $311 \mathrm{pw}$ & $\mathrm{Fe}(0)$, Control, Pore Water & Flooded & 2 \\
\hline 44 & $311 \mathrm{pw} / \mathrm{a}$ & $\mathrm{Fe}(0)$, Pore Water Acidified & Flooded & 1 \\
\hline 45 & 311 exch & $\mathrm{Fe}(0)$, Control, Exchangeable & Flooded & 1 \\
\hline 46 & 311 org & $\mathrm{Fe}(0)$, Organic & Flooded & 1 \\
\hline 47 & $311 \mathrm{Fe}$ & $\mathrm{Fe}(0)$, Crystalline Fe-oxide & Flooded & 1 \\
\hline 48 & 311Tot & $\mathrm{Fe}(0)$, Total Residue & Flooded & 1 \\
\hline 49 & $313 \mathrm{pw}$ & Control, Pore Water & Wet/Dry & 2 \\
\hline
\end{tabular}


WSRC-TR-2002-00370, Rev. 0

Page 62

\begin{tabular}{|c|c|c|c|c|}
\hline 50 & $313 \mathrm{pw} / \mathrm{a}$ & Control, Pore Water Acidified & Wet/Dry & 1 \\
\hline 51 & $313 \mathrm{exch}$ & Control, Exchangeable & Wet/Dry & 1 \\
\hline 52 & 313org & Control, Organic & Wet/Dry & 1 \\
\hline 53 & $313 \mathrm{Fe}$ & Control, Crystalline Fe-oxide & Wet/Dry & 1 \\
\hline 54 & 313Tot & Control, Total Residue & Wet/Dry & 1 \\
\hline 55 & 314-pw & Control, Pore Water & Wet/Dry & 2 \\
\hline 56 & $314 \mathrm{pw} / \mathrm{a}$ & Control, Pore Water Acidified & Wet/Dry & 1 \\
\hline 57 & $314 \mathrm{exch}$ & Control, Exchangeable & Wet/Dry & 1 \\
\hline 58 & 314org & Control, Organic & Wet/Dry & 1 \\
\hline 59 & $314 \mathrm{Fe}$ & Control, Crystalline Fe-oxide & Wet/Dry & 1 \\
\hline 60 & 314Tot & Control, Total Residue & Wet/Dry & 1 \\
\hline 61 & $316 \mathrm{pw}$ & Apatite, Pore Water & Wet/Dry & 2 \\
\hline 62 & $316 \mathrm{pw} / \mathrm{a}$ & Apatite, Pore Water Acidified & Wet/Dry & 1 \\
\hline 63 & 316 exch & Apatite, Exchangeable & Wet/Dry & 1 \\
\hline 64 & 316org & Apatite, Organic & Wet/Dry & 1 \\
\hline 65 & $316 \mathrm{Fe}$ & Apatite, Crystalline Fe-oxide & Wet/Dry & 1 \\
\hline 66 & 316Tot & Apatite, Total Residue & Wet/Dry & 1 \\
\hline 67 & $317 \mathrm{pw}$ & Apatite, Pore Water & Wet/Dry & 2 \\
\hline 68 & $317 \mathrm{pw} / \mathrm{a}$ & Apatite, Pore Water Acidified & Wet/Dry & 1 \\
\hline 69 & $317 \mathrm{exch}$ & Apatite, Exchangeable & Wet/Dry & 1 \\
\hline 70 & 317org & Apatite, Organic & Wet/Dry & 1 \\
\hline 71 & $317 \mathrm{Fe}$ & Apatite, Crystalline Fe-oxide & Wet/Dry & 1 \\
\hline 72 & 317Tot & Apatite, Total Residue & Wet/Dry & 1 \\
\hline 73 & $319 \mathrm{pw}$ & Apatite\&Fe $(0)$, Pore Water & Wet/Dry & 2 \\
\hline 74 & $319 \mathrm{pw} / \mathrm{a}$ & Apatite\&Fe $(0)$, Pore Water Acidified & Wet/Dry & 1 \\
\hline 75 & $319 \mathrm{exch}$ & Apatite\&Fe(0), Exchangeable & Wet/Dry & 1 \\
\hline 76 & 319org & Apatite\&Fe(0), Organic & Wet/Dry & 1 \\
\hline 77 & $319 \mathrm{Fe}$ & Apatite\&Fe(0), Crystalline $\mathrm{Fe}$-oxide & Wet/Dry & 1 \\
\hline 78 & 319Tot & Apatite\&Fe(0), Total Residue & Wet/Dry & 1 \\
\hline 79 & $320 \mathrm{pw}$ & Apatite\&Fe $(0)$, Pore Water & Wet/Dry & 2 \\
\hline 80 & $320 \mathrm{pw} / \mathrm{a}$ & Apatite\&Fe $(0)$, Pore Water Acidified & Wet/Dry & 1 \\
\hline 81 & $320 \mathrm{exch}$ & Apatite\&Fe(0), Exchangeable & Wet/Dry & 1 \\
\hline 82 & 320org & Apatite\&Fe(0), Organic & Wet/Dry & 1 \\
\hline 83 & $320 \mathrm{Fe}$ & Apatite\&Fe(0), Crystalline Fe-oxide & Wet/Dry & 1 \\
\hline 84 & 320Tot & Apatite\&Fe(0), Total Residue & Wet/Dry & 1 \\
\hline 85 & $322 \mathrm{pw}$ & $\mathrm{Fe}(0)$, Pore Water & Wet/Dry & 2 \\
\hline 86 & $322 \mathrm{pw} / \mathrm{a}$ & $\mathrm{Fe}(0)$, Pore Water Acidified & Wet/Dry & 1 \\
\hline 87 & $322 \mathrm{exch}$ & $\mathrm{Fe}(0)$, Exchangeable & Wet/Dry & 1 \\
\hline 88 & 322org & $\mathrm{Fe}(0)$, Control, Organic & Wet/Dry & 1 \\
\hline 89 & $322 \mathrm{Fe}$ & $\mathrm{Fe}(0)$, Control, Crystalline Fe-oxide & Wet/Dry & 1 \\
\hline 90 & 322Tot & $\mathrm{Fe}(0)$, Control, Total Residue & Wet/Dry & 1 \\
\hline 91 & $323 \mathrm{pw}$ & $\mathrm{Fe}(0)$, Control, Pore Water & Wet/Dry & 2 \\
\hline 92 & $323 \mathrm{pw} / \mathrm{a}$ & $\mathrm{Fe}(0)$, Pore Water acidified & Wet/Dry & 1 \\
\hline 93 & 323exch & $\mathrm{Fe}(0)$, Control, Exchangeable & Wet/Dry & 1 \\
\hline 94 & 323org & $\mathrm{Fe}(0)$, Organic & Wet/Dry & 1 \\
\hline 95 & $323 \mathrm{Fe}$ & $\mathrm{Fe}(0)$, Crystalline Fe-oxide & Wet/Dry & 1 \\
\hline 96 & 323Tot & $\mathrm{Fe}(0)$, Total Residue & Wet/Dry & 1 \\
\hline
\end{tabular}


Table 4B. Dry weight measurements.

\begin{tabular}{|c|c|c|c|c|c|}
\hline ID\# & Treatment & Rep & $\begin{array}{l}\text { Al Pan Tare Wt, } \\
\text { betw. } 2 \text { \& } 3 \text { g (g) }\end{array}$ & $\begin{array}{c}\text { Al Pan + Wet Soil } \\
\text { Wt (g) }\end{array}$ & $\begin{array}{c}\text { Al Pan + Dry Soil } \\
\text { Wt. (g) }\end{array}$ \\
\hline $301 \mathrm{a}$ & 301 & A & & & \\
\hline $301 b$ & 301 & $\mathrm{~B}$ & & & \\
\hline $302 a$ & 302 & A & & & \\
\hline $302 b$ & 302 & $\mathrm{~B}$ & & & \\
\hline $304 a$ & 304 & $\mathrm{~A}$ & & & \\
\hline $304 b$ & 304 & $\mathrm{~B}$ & & & \\
\hline $305 a$ & 305 & $\mathrm{~A}$ & & & \\
\hline $305 b$ & 305 & $\mathrm{~B}$ & & & \\
\hline $307 a$ & 307 & $\mathrm{~A}$ & & & \\
\hline $307 b$ & 307 & $\mathrm{~B}$ & & & \\
\hline $308 \mathrm{a}$ & 308 & A & & & \\
\hline $308 b$ & 308 & $\mathrm{~B}$ & & & \\
\hline $310 \mathrm{a}$ & 310 & $\mathrm{~A}$ & & & \\
\hline $310 b$ & 310 & $\mathrm{~B}$ & & & \\
\hline $311 \mathrm{a}$ & 311 & A & & & \\
\hline $311 \mathrm{~b}$ & 311 & $\mathrm{~B}$ & & & \\
\hline $313 a$ & 313 & A & & & \\
\hline $313 b$ & 313 & $\mathrm{~B}$ & & & \\
\hline $314 a$ & 314 & $\mathrm{~A}$ & & & \\
\hline $314 b$ & 314 & B & & & \\
\hline $316 a$ & 316 & $\mathrm{~A}$ & & & \\
\hline $316 b$ & 316 & $\mathrm{~B}$ & & & \\
\hline $317 \mathrm{a}$ & 317 & A & & & \\
\hline $317 b$ & 317 & B & & & \\
\hline $319 a$ & 319 & $\mathrm{~A}$ & & & \\
\hline $319 b$ & 319 & $\mathrm{~B}$ & & & \\
\hline $320 a$ & 320 & A & & & \\
\hline $320 b$ & 320 & $\mathrm{~B}$ & & & \\
\hline $322 a$ & 322 & $\mathrm{~A}$ & & & \\
\hline $322 b$ & 322 & $\mathrm{~B}$ & & & \\
\hline $323 a$ & 323 & A & & & \\
\hline $323 b$ & 323 & $\mathrm{~B}$ & & & \\
\hline
\end{tabular}

